UNIVERSIDADE DE SÃO PAULO

INSTITUTO DE QUIMICA

\title{
ESTUDO DOS MECANISMOS ENVOLVIDOS NO CONTROLE POR CAMP DA EXPRESSĀO DO GENE PARA UMA MOLÉCULA DE ADESÃO EM Dictyostelium discoideum
}

GLÁUCIA MENDES SOUZA

Orientadora: Profa. Dra. Aline Maria da Silva

Tese de Doutoramento apresentada ao Departamento de Bioquímica, Instituto de Química

Universidade de São Paulo

SÃO PAULO

1993 


\title{
"ESTODO DOS MECANISMOS ENVOLVIDOS NO CONTROLE POR CAMP DA EXPRE88ÃO DO GENE PARA UKA MOLÉCULA DE ADE8ÃO EM Dictyostelium discoideum"
}

\author{
GLÁUCIA MENDES BOUZA
}

Tese de Doutorado submetida ao Instituto de Química da Universidade de são Paulo como parte dos requisitos necessários à obtenção do grau de Doutor em Ciências - Área: Bioquímica.

\section{Aprovada por:}

\begin{tabular}{c} 
Profa. Dra. Aline Maria da Silva \\
IQ-USP \\
(Orientadora e Presidenta) \\
\hline Profa. Dra. Karla Kovary \\
IQ-USP \\
\hline Profa. Dra. Lucile Maria Floeter Winter \\
ICB-USP \\
\hline Profa. Dra. Marie Anne Van Sluys \\
IB-USP \\
Profa. Dra. Beatriz Amaral de Castilho Valavícius \\
EPM
\end{tabular}

SÃo PAULO, SP

02 DE DEZEMBRO DE 1993 
Aos meus pais, Antônio e Miranda, por sempre me apoiarem com muito amor. 
Agradeço

à Dra. Aline Maria da Silva, por ter assumido a minha orientação com amizade, coragem e competência permitindo que este trabalho fosse realizado com sucesso. 


\section{AGRADECIMENTOS}

Ao Dr. José Carlos da Costa Maia pelo grande apoio e orientação quando do falecimento da Dra. Maria Helena Juliani e sempre.

Ao Dr. Robert Ivan Schumacher por todo carinho com que orientou meu estágio de Iniciação Científica e mais recentemente pela ajuda com o Macintosh.

À Dra. Claudette Klein, nossa colaboradora em St. Louis, pela atenção constante durante todo o projeto e no meu estágio em seu laboratório.

À Dra. Suely Lopes Gomes pela atenção especial em alguns momentos difíceis e pelo empréstimo de algumas enzimas de restrição.

Ao Antonio Amorim por estar ao meu lado em todos os momentos.

Aos amigos de muitos anos de Bioquímica, Elizabeth Martins, Margareth Capurro, Miguel Ortega, Armando Ventura, Irenice Cairo da Silva, Dna. Maria do Céu Queijo de Sá Moraes, Alberto de Mello (in memorian) e Dr. Rogério Meneghini pelos anos divertidos que passamos juntos.

À Ana Cláudia Cantisani Borges e Júlio César Franco de Oliveira por terem nesses anos se tomado amigos que nunca esquecerei.

A Cintia Renata Rocha, Marcelo Avedissian, Marilis do Valle Marques, Lilian Etchebehere, Marly Cunha da Silva, Robert Sablowski, Adriana Clerici de Maria, Débora Colombi, Paulo Ribolla, Rosângela Campanhã, Patrícia Brandt, Hernán Terenzi, Rosane Stefani, José Antonio Novaes da Silva, Mara Lúcia Zucheran Silvestri, Andréa Regatão, Camilo Cabral, Sr. José Lino, Pio Zapella e Fátima de Melo por milhões de motivos nestes muitos anos de amizade.

À Adriana Pivi e Jim Murray pela ajuda em alguns experimentos.

À Dra. Mari Armelin pelo gentil empréstimo do aparato de "dot blots".

Ao Onofre Custódio da Silva pela confecção das fotografias, ao Francisco Divino e Jailton Serino pela confeç̧ão das cópias xerográficas e à Maria do Carmo Neves, Cibele Rosane Carlos, Vilma Tofolo dos Reis, Kalliope Katsios e Rosemary dos Santos da Secretaria de Pós-graduação.

Ao Mario Lopes Duarte pela síntese dos nucleotídeos radioativos.

Este trabalho foi realizado com o auxilio financeiro da FAPESP, FINEP e CNPq aos Drs. Maria Helena Juliani e José Carlos da Costa Maia e FAPESP e CNPq-PADCT aos Drs. Aline Maria da Silva e José Carlos da Costa Maia. A autora foi bolsista do CNPq (1987-1989) e da FAPESP (1990-1993) e contou com bolsa "sanduíche" da 
CAPES durante estágio de 3 meses no laboratório da Dra. Claudette Klein (St. Louis, EUA, 1990). 


\section{ÍNDICE}

ABREVIATURAS i

RESUMO iii

SUMMARY iv

I - INTRODUÇÃO

1 - Ciclo de vida de Dictyostelium discoideum 2

2 - O papel do cAMP no desenvolvimento de Dictyostelium discoideum $\quad \mathbf{5}$

3 - Características do receptor de cAMP (CAR1) que media a transdução $\begin{array}{ll}\text { de sinal durante as primeiras horas do desenvolvimento } & \mathbf{8}\end{array}$

4 - Adesão celular durante o desenvolvimento em Dictyostelium $\begin{array}{ll}\text { discoideum } & 10\end{array}$

5 - Controle da expressão gênica em Dictyostelium discoideum 12

6 - Objetivos 14

II - PROCEDIMENTO EXPERIMENTAL 16

$\begin{array}{ll}1 \text { - Materiais } & 16\end{array}$

1.1 - Reagentes 16

1.2 - Enzimas e kits $\quad 16$

1.3 - Material radioativo 16

1.4 - Outros 16

2 - Bactérias e vetores $\quad 16$

2.1 - Cepas de E. coli utilizadas $\quad 16$

2.2 - Vetores 16

3 - Condições de cultivo e obtenção das células de Dicyostelium $\begin{array}{ll}\text { discoideum } & 17\end{array}$

$\begin{array}{ll}3.1 \text { - Manutenção das culturas } & 17\end{array}$

3.2 - Cultivo em meio líquido e obtenção de células competentes $\begin{array}{ll}\text { para agregação } & 17\end{array}$

3.3 - Tratamento das células com diferentes compostos 17

3.4 - Transformação de Dictyostelium 18

4 - Isolamento de RNA de Dictyostelium discoideum 18

5 - Eletroforese de RNA em gel de agarose 19

6- Transferência de RNA para filtro de nitrocelulose ("Northem")
e hibridização RNA-DNA

7 - Preparação de sondas de DNA radioativas $\quad 20$

7.1 - "Nick-translation" 20 
7.2 - "Random Primed Synthesis"

8 - Isolamento de núcleos e ensaio de "run-off" nuclear 21

9 - Ensaio de Pulso e Caça

10 - Ensaio de tomada de ${ }^{45} \mathrm{Ca}^{2+} \quad 22$

11 - Digestão de DNA com enzimas de restrição 23

12 - Eletroforese de DNA 23

12.1 - Gel de agarose $\quad 23$

12.2 - Gel de poliacrilamida $\quad 23$

13 - Eluição de DNA de gel de agarose e quantificação 24

13.1 - Eluição por fenol $\quad 24$

13.2 - Eletroeluição $\quad 24$

13.3 - Quantificação do DNA após a eluição $\quad 24$

14 - Eluição de DNA de gel de poliacrilamida 25

15 - Desfosforilação de plasmídeo linearizado 25

16 - Reação de ligação de DNA 25

17 - Preparação de bactérias competentes para transformação 25

17.1 - Método utilizando cálcio $\quad 25$

17.2 - Método de Hanahan $\quad 26$

18 - Preparação de plasmídeos $\quad 26$

$\begin{array}{ll}18.1 \text { - Minipreparação } & 26\end{array}$

18.2 - Preparação em larga escala $\quad 27$

19 - Preparação de DNA de $\lambda$ gt10 28

19.1 - Minipreparação $\quad 28$

19.2 - Preparação em larga escala $\quad 28$

20 - Eletroforese de proteinas em gel de poliacrilamida (SDS-PAGE) 29

21 - Transferência eletroforética de proteínas de géis de poliacrilamida para filtros de nitrocelulose e deteç̧ão imunológica das proteínas do "blot" 30

III - RESULTADOS 31

1 - Isolamento e caracterização de um gene regulado por cAMP em Dictyostelium discoideum $\quad 31$

1.1 - Análise dos clones positivos isolados da biblioteca de cDNA do mutante Agip45 31

1.2 - Caracterização do clone 41

2 - Estudo da regulação da expressão do mRNA para gp80 em resposta a CAMP 
2.1 - Efeito de pulsos de cAMP na expressão do mRNA para gp80

2.2 - Efeito de concentrações altas e constantes de cAMP nos niveis do mRNA para gp80

2.3 - Análise do nivel molecular em que a "down-regulation" do receptor induz a diminuição nos niveis do mRNA para gp80

3 - Estudo das vias de transdução de sinal ativadas durante a desestabilização do mRNA para gp80

3.1 - Análise do papel de íons de cálcio

3.2 - Envolvimento da proteina quinase $\mathrm{C}$ na regulação da desestabilização do mRNA para gp80

4 - Estudo da desestabilização do mRNA para gp80 em outras fases do desenvolvimento

4.1 - Construção da quimera gp80-suc

4.2 - Obtenção de linhagens de dictyostelium que expressam a quimera gp80-suc constitutivamente

4.3 - Estudo da estabilidade do mRNA para gp80-suc 


\section{ABREVIATURAS}




PMA - forbol 12-miristato 13-acetato

Proteína $\mathrm{G}$ - proteína regulatória que liga nucleotideo de guanina

RNAse - ribonuclease

SDS - dodecil sulfato de sódio

TCA - ácido tricloro acético

TMB-8 - 8-(N,N-dietilamino)octil-3,4,5-trimetoxi-benzoato

Tris - tris(hidroximetil)-aminometano

UTP - trifosfato de uridina

UV - ultravioleta

X-gal - 5 bromo-4 cloro-3 indolil- $\beta$-D-galactosídeo 


\section{RESUMO}

O objetivo inicial deste trabalho foi estudar a expressão de genes regulados por cAMP durante o desenvolvimento do eucarioto inferior Dictyostelium discoideum. Foram analisados vários clones de uma biblioteca de cDNA construída a partir de mRNAs de células estimuladas com cAMP. A análise de um destes clones revelou que este codificava para a proteína de adesão celular gp80, que é expressa durante a fase de agregação no início do desenvolvimento.

A regulação da expressão do gene da gp80 foi então estudada. Baixas concentrações de cAMP induzem o aparecimento de mRNA para gp80. A indução ocorre via o receptor de cAMP da superfície celular, e por um mecanismo que não envolve mudanças de CAMP intracelular. Por outro lado, altas concentrações de CAMP, que levam à "down-regulation" do receptor de CAMP, causarn uma rápida desestabilização do mRNA para gp80 em células competentes para agregação.

O mecanismo pelo qual cAMP em altas concentrações desestabiliza o mRNA para gp80 foi investigado. Foi observado que este tratamento, também causa um aumento da tomada de $\mathrm{Ca}^{2+}$. Devido à esta observação, nós procuramos um papel para $\mathrm{Ca}^{2+}$ como um mensageiro secundário na degradação do mRNA para gp80. Mudanças nos niveis de mRNA foram examinadas após tratamento das células com compostos que alteram a concentração intracelular de $\mathrm{Ca}^{2+}$. A soma dos dados sugere que um influxo de cálcio através da membrana celular, em oposição à liberação de cálcio de compartimentos intracelulares, ativa a degradação do mRNA para gp80. Além disso, incubação das células com um inibidor da proteína quinase $C$ previne parcialmente a ação do CAMP, sugerindo um papel para proteína quinase $C$ neste fenômeno.

A regulação por cAMP da estabilidade do mRNA para gp80 foi também estudada durante o crescimento vegetativo de uma linhagem de $D$. discoideum que expressa constitutivamente o cDNA para gp80. Os resultados indicam que, assim como as células da fase de agregação, as células da fase de crescimento também possuem os elementos necessários para degradar a mensagem para gp80 em resposta a um aumento na concentração intracelular de cálcio. Contudo, estas células não são capazes de degradar a mensagem em resposta a altas concentrações de cAMP. 


\section{SUMMARY}

The initial goal of the present work was the study of gene expression regulated by cAMP in Dictyostelium discoideum development. For this, several cDNA clones, from a library constructed using mRNA of cells stimulated with CAMP, were analyzed. Analysis of one of this clones showed that it corresponded to gp80, a cell adhesion molecule expressed during cell aggregation in early development.

gp80 gene regulation was then studied. Low concentrations of CAMP induces gp80 mRNA expression. The induction seems to be via the cell surface cAMP receptor and by a mechanism that does not involve changes in intracellular cAMP. Interestingly, high concentrations of CAMP, which down-regulate the cell surface cAMP receptor, elicit destabilization of gp80 mRNA in agregation competent cells.

The mechanism by which high concentrations of cAMP selectively destabilize the gp80 mRNA was investigated. This treatment which leads to down-regulation of the CAMP receptor was found to also cause an increase in calcium uprake. Given this observation, we sought a role for calcium as a second messenger in the degradation of the gp80 mRNA. Changes in the mRNA levels were examined after treating cells with compounds known to alter the intracellular $\mathrm{Ca}^{2+}$ concentrations. The sum of the data suggest that it is the cAMP-induced influx of $\mathrm{Ca}^{2+}$ across the plasma membrane, as apposed to a CAMP-mediated release of $\mathrm{Ca}^{2}+$ from intracellular stores, that initiates gp80 mRNA degradation. Also, cell incubation with staurosporin partially prevents the action of CAMP, implicating a possible role of protein kinase $C$.

Regulation by CAMP of the message stability during vegetative growth was also studied in cells which constitutively express the gp80 cDNA. The results indicate that like aggregation competent cells, these cells are able to evoque destabilization of the mRNA in response to a raise in intracellular calcium concentration. However, they are unable to induce the mRNA degradation after cAMP treatment. 


\section{I - INTRODUÇÃO}

A capacidade de responder a sinais extracelulares é essencial para a sobrevivência e desenvolvimento de todos os organismos vivos. Entre as consequências desta resposta estão alterações no programa e no nível de expressão de genes específicos. Tanto em procariotos quanto em eucariotos, a regulação dos niveis de expressão de uma determinada proteína ocorre principalmente através do controle da transcrição do seu gene. Além disso, tais niveis podem ser regulados através do processamento pós-transcricional, do controle da estabilidade do seu mRNA, ou ainda através de controles ao nível da tradução ou pós-tradução (Damell, 1990).

Os elementos bioquímicos envolvidos no controle da expressão gênica em resposta a sinais extracelulares têm sido vastamente estudados nos últimos anos (para revisão Karin, 1992; Van Haastert et al., 1991). Como em bactérias, a transdução do sinal em eucariotos é iniciada por uma interação entre um ligante e um receptor. Os ligantes identificados incluem proteínas solúveis, peptídeos ou pequenas moléculas orgânicas, como por exemplo neurotransmissores, hormônios e fatores de crescimento. Os receptores podem ser agrupados em três classes: os ligados a canais de íons, que estão envolvidos na rápida sinalização induzida por neurotransmissores, os receptores catalíticos, que quando ativados por ligantes agem como enzimas e fosforilam seus alvos em residuos de tirosina, como os receptores de fatores de crescimento e insulina, e os receptores ligados a proteínas $G$, que por sua vez ativam uma variedade de outros elementos como a adenilato ciclase, guanilato ciclase, fosfolipase $\mathrm{C}$ e canais de íons.

A interação do ligante (mensageiro primário) com o receptor presente na superfície da célula leva à produção de sinais intracelulares (mensageiros secundários) como por exemplo cAMP, íons de cálcio, inositol-fosfatos, diacilglicerol e cGMP (Karin, 1992; Van Haastert et al., 1991). Os mensageiros secundários por sua vez podem regular atividades enzimáticas específicas e/ou provocar variações na expressão gênica. Já foram identificados, por exemplo, elementos reguladores responsivos a cAMP em promotores de diversos genes (Roesler et al., 1988). Este mensageiro secundário, gerado pela ativação da adenilato ciclase via um receptor age ativando a proteina quinase dependente de CAMP (PKA), que fosforila alguns fatores de transcrição como o CREB (proteina que liga elementos regulados por cAMP) (Gonzalez et al., 1989; Karin, 1992) que por sua vez se liga a regióes promotoras de vários genes regulados por cAMP. Associado a este papel regulador da transcrição 
gênica, é possível que cAMP possa exercer sua ação através do controle da estabilidade de mRNAs (Brawerman, 1987), ainda que este fenômeno não esteja muito bem documentado.

Todos os níveis de regulação da expressão gênica estão intimamente relacionados, e podem, muitas vezes, participar simultâneamente do controle dos niveis de uma determinada proteína. Assim, um estudo completo da regulação da expressão de uma proteína requer portanto, a determinação dos sinais moleculares aos quais o gene responde, do nivel da cadeia de eventos em que o controle é exercido e dos mecanismos moleculares envolvidos em cada nível do controle gênico. Com esta perspectiva, nos propusemos a estudar o controle da expressão gêrica do gene para a proteína de adesão celular gp80 de Dictyostelium discoideum. As características singulares do seu ciclo de vida, a simplicidade estrutural, e as amplas possibilidades de manipulação deste microorganismo através de técnicas genéticas e bioquímicas, o tornam um modelo muito adequado para o estudo dos diversos mecanismos envolvidos na regulação da expressão gênica em resposta a sinais extracelulares que são gerados durante o desenvolvimento.

\section{1 - Ciclo de vida de Dictyostelium discoideum}

Dictyostelium discoideum é um eucarioto da classe Eumycetozoea que apresenta um ciclo de vida assexual com duas fases distintas: o crescimento vegetativo e o desenvolvimento. Na natureza este organismo habita o solo e o húmus, alimentando-se de bactérias por fagocitose. Este ciclo pode ser facilmente reproduzido em laboratório, onde células de linhagens selvagens podem ser crescidas em placas de ágar sólido sobre uma camada de bactérias, duplicando a cada 3 horas. Alternativamente, estão disponiveis linhagens axênicas que crescem em cultura líquida com um tempo de duplicação de 8 horas. $\mathrm{Na}$ fase de crescimento, as amebas crescem isoladas podendo chegar a uma densidade de $10^{10}$ células por litro (Loomis, 1982; Devreotes, 1989).

A carência nutricional a qualquer momento durante a fase de crescimento, induz o programa de desenvolvimento, com duração aproximada de 24 horas, que caracteriza-se pela agregação de cerca de $10^{5}$ amebas solitárias para a formação de um organismo multicelular composto de 2 tipos celulares distintos: células-talo e esporos, como esquematizado na fig. 1 (para revisão, ver Loomis, 1982; Devreotes, 1989). Aproximadamente 2 horas após a remoção de nutrientes algurnas amebas da população começam a secretar cAMP na forma de pulsos com a frequência de um pulso a cada 6-9 minutos. O cAMP secretado age como um quimioatrativo e dirige a 


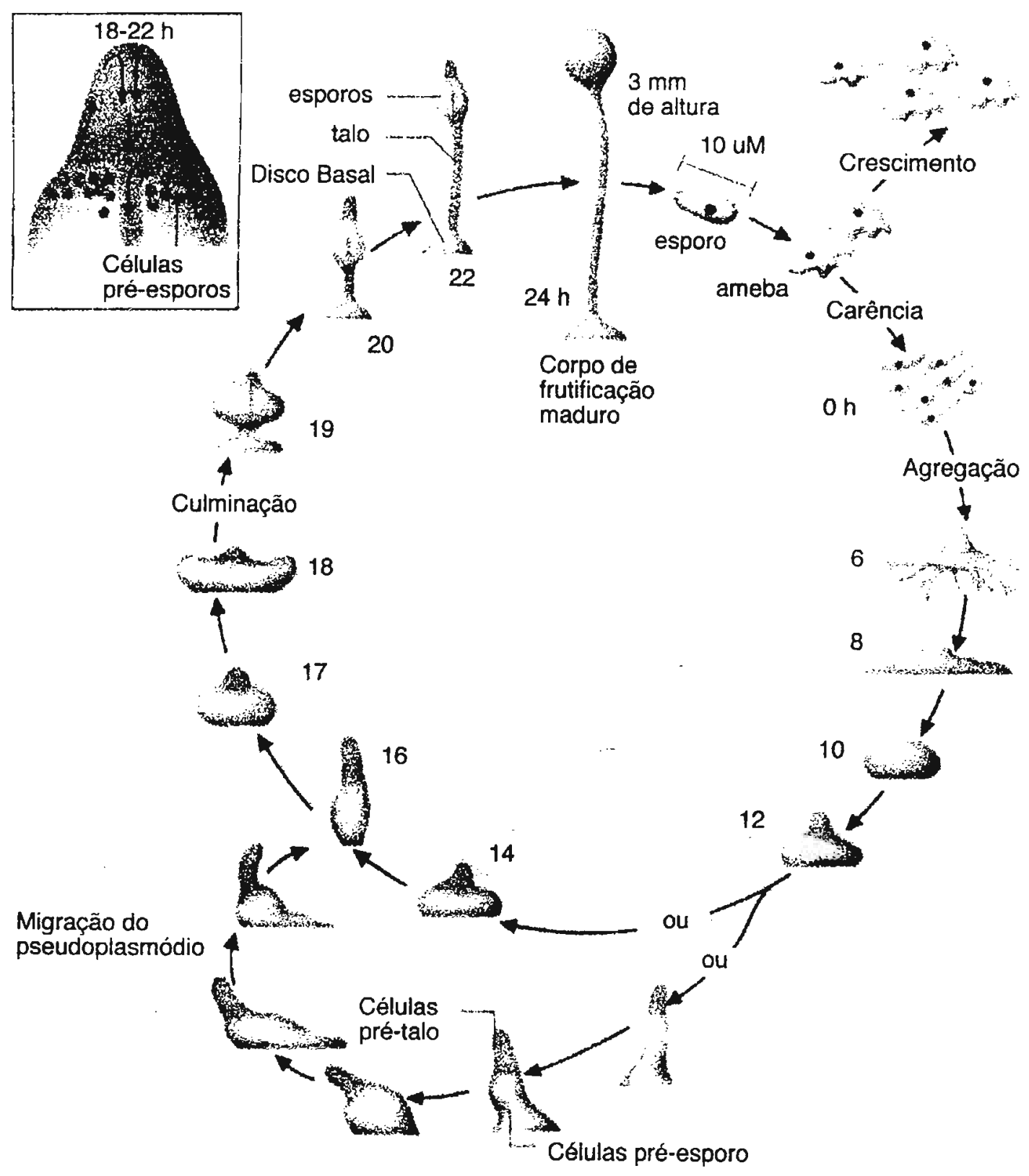

Fig. 1 - Ciclo de vida de Dictyostelium discoideum. Adaptado de Damell et al. (1990). Em detalhe o organismo durante o processo de culminação. 
migração das células vizinhas para os centros que iniciaram a produção do sinal quimiotático (centros de agregação). A agregação das células é organizada pelo AMP cíclico (cAMP) através de um sistema composto do receptor de cAMP, adenilato ciclase, uma fosfodiesterase de cAMP e de seu inibidor. Quando submetidas a carência sobre uma superfície sólida, as células se movem no gradiente de concentração de cAMP produzido, num movimento coordenado que dura aproximadamente 2 minutos, seguido de um período de 5 a 7 minutos durante o qual a migração é interrompida. A migração das células guiada pelo cAMP depende da ligação deste a receptores específicos, que sofrem adaptação quando a concentração de CAMP no meio é constante. Além de responder ao sinal quimiotático com migração, as células vizinhas ao centro de agregação também secretam pulsos de cAMP, amplificando o sinal para atração de outras amebas mais distantes. Quando a concentração de cAMP no meio se torna constante, as células param de produzir CAMP, e secretam uma fosfodiesterase que degrada o cAMP acumulado. Isto faz com que as células se tornem novamente responsivas ao agente quimiotático, reiniciem a migração e retomem a produção de cAMP para amplificar o sinal.

Durante a migração as células adquirem uma forma alongada, se tornam mutuamente adesivas, e formam pontos de contato célula-célula entre suas extremidades polares, apresentando uma formação semelhante a "correntes" ("streams"). O agregado de $10^{5}$ células formado após este periodo é a princípio arredondado, assumindo em seguida uma forma cilíndrica alongada verticalmente ("finger"). Em condições apropriadas esta estrutura assume uma orientação horizontal sobre o substrato, e o organismo, agora chamado pseudoplasmódio ("slug"), é capaz de deslocar-se em busca de condições mais favoráveis, migrando em direção à luz, umidade ou calor, pois suas células, ainda que individualizadas, estão confinadas em um invólucro flexível, constituído de polissacarídeos. Nesta fase vários tipos celulares já podem ser distinguíveis. Na região anterior, correspondendo a 1/4 do total das células, se localizam as células destinadas a se tornar talo (células pré-talo). 0 restante posterior do pseudoplasmódio contém células que se diferenciarão em esporos (células pré-esporo). Dispersas na região posterior do pseudoplasmódio existem ainda células semelhantes as células pré-talo. Após um período de migração que pode se estender por vários dias, a extremidade anterior do pseudoplasmódio cessa o movimento para a frente, enquanto o restante das células continuam a migrar, até que estejam localizadas na sua parte inferior. Neste estágio, chamado culminação, as células-talo começam a ser formadas na extremidade da região pré-talo. As célulastalo são formadas por vacuolização intensa das células pré-talo, e estão destinadas a 
morrer pela deposição de celulose e consequente espessamento da membrana celular. Concomitantemente a este processo, ocorre migração das células pré-talo através da região que contém as células pré-esporos, num movimento similar a uma "fonte invertida", empurrando as células que vão se destinar à formação do talo para a região basal do organismo, através da zona pré-esporo (ver detalhe na fig. 1). Quando as células-talo alcançam a base, células que originalmente se localizavam na região posterior do pseudoplasmódio também se tornam vacuolizadas, formando o disco basal, terminologia que deu origem ao nome Dictyostelium discoideum. Enquanto as células-talo migram para a região basal, a região pré-esporo começa a ser elevada por este movimento, e durante este período ocorre a diferenciação das células pré-esporos em esporos maduros, sendo que cada célula pré-esporo produz um envoltório de celulose. No final deste processo uma cápsula contendo os esporos é sustentada por um talo em uma estrutura de aproximadamente $3 \mathrm{~mm}$ chamada de corpo de frutificação. Eventualmente, na presença de nutrientes, os esporos liberados germinam dando origem a células amebóides capazes de iniciar o crescimento vegetativo.

\section{2 - O papel do cAMP no desenvolvimento de Dictyostelium discoideum}

O processo de agregação celular que ocorre no início do desenvolvimento é organizado em resposta ao cAMP. No intervalo de tempo que antecede a agregação, as células de Dictyostelium se tornaram aptas a responder quimiotaticamente aos pulsos de cAMP e a transmitir este sinal para as células vizinhas, estando, portanto, competentes para agregação. As oscilações da concentração de cAMP em níveis nanomolares ocorrem com uma periodicidade de 6 minutos, produzindo pulsos de CAMP que dirigem as outras amebas da população para centros de agregação. A resposta ao cAMP é mediada por receptores específicos presentes na superficie da célula (para revisão, ver Gerisch, 1987; Firtel et al., 1989). A ligação do cAMP ao receptor (ver fig. 2) induz rapidamente a ativação da guanilato ciclase aumentando os níveis intracelulares de cGMP, o que parece estar intimamente relacionado com o fenômeno de quimiotaxia (Ross e Newell, 1981). Concomitantemente, a estimulação do receptor pelo CAMP leva à ativação da fosfolipase $C$ que por sua vez aumenta os níveis de $\mathrm{IP}_{3}$ intracelulares (Europe-Finner e Newell, 1987). Os niveis de $\mathrm{Ca}^{2+}$ intracelulares também são regulados pelo sinal de CAMP, através da mobilização de cálcio de compartimentos intracelulares sensiveis a $\mathrm{IP}_{3}$ e pela ativação de canais de cálcio (Milne e Coukell, 1991). A ativação da adenilato ciclase pela ligação de CAMP ao seu receptor é mais lenta que a ativação da guanilato ciclase e da fosfolipase $C$. 
RESPOSTA RÁPIDA



Fig. 2 - Vias de transdução de sinal ativadas pela ligação de CAMP ao receptor que mediam a transdução de sinal durante as primeiras horas de carência. Adaptado de Firtel, 1991. R, receptor de cAMP. PDE, fosfodiesterase de cAMP. G $\alpha 2 \beta \gamma$, subunidades da proteina G. GC, guanilato ciclase. PLC, fosfolipase C. PKC, proteína quinase dependente de cálcio. PKA, proteína quinase dependente de cAMP. D, receptor de cAMP dessensibilizado. AC, adenilato ciclase. G, proteína G. GRP, proteína regulatória da proteína $G$. DAG, diacilglicerol. $I P_{3}$, inositol trifosfato. $\mathrm{PIP}_{2}$, fosfatidil inositol difosfato. 
Enquanto o acúmulo de cGMP e $\mathrm{IP}_{3}$ é máximo após 10 segundos da estimulação do receptor, 1 a 2 minutos são necessários para que níveis máximos de atividade da adenilato ciclase sejam observados, resultando em um rápido aumento nos niveis de CAMP tanto intracelular quanto secretado. Estimulação das células com níveis constantes de cAMP levam à adaptação do receptor, coincidente com a sua fosforilação e com a adaptação da adenilato ciclase, guanilato ciclase e fosfolipase $C$. As células param então de produzir cAMP, e uma fosfodiesterase secretada degrada o CAMP do meio tornando o receptor novamente responsivo ao sinal quimiotático. Deste modo as células percebem a mudança nos níveis extracelulares de cAMP e movem-se em direção ao gradiente de concentração crescente, resultando na formação do agregado celular (para revisão ver, Gerisch, 1987; Janssens e Van Haastert, 1987).

A ativação das três vias descritas acima parece ser mediada por proteínas $G$ heterotriméricas, que são complexos protéicos que ligam GTP, constituídos das subunidades $\alpha, \beta$ e $\gamma$ (Gilman, 1987). Diferentes genes para subunidades $\alpha$ foram identificados em Dictyostelium discoideum e a subunidade Ga2 parece estar envolvida na transdução do sinal do receptor para a guanilato ciclase e fosfolipase C (SnaarJagalska et al., 1988). Mutantes desta subunidade de proteína $G$, chamados frigidA (fig. 2) (Coukell et al., 1983), não respondem a cAMP com ativação da guanilato ciclase e fosfolipase C (Snaar-Jagalska et al., 1988; Kumagai et al., 1989), e in vivo também não são capazes de ativar a adenilato ciclase. No entanto, GTP $\gamma$ S é capaz de ativar a adenilato ciclase nestes mutantes, indicando que uma subunidade $\mathrm{G} \alpha$ diferente de $\mathrm{G} \alpha 2$ deve regular esta enzima (Snaar-Jagalska et al., 1988; Kumagai et al., 1989). Além disso, acúmulo de $\mathrm{IP}_{3}$ parece estar envolvido na ativação da adenilato ciclase in vivo, o que justificaria o envolvimento indireto de $G \alpha 2$ na via de ativação da adenilato ciclase (Snar-Jagalska et al., 1988). Estudos de um outro mutante incapaz de ativar a adenilato ciclase denominado Synag7 (fig. 2), indicam que a ativação da adenilato ciclase envolve também um fator protéico (GRP, proteina regulatória da proteína G), sem o qual esta enzima não é ativada pelo receptor (Theibert e Devreotes, 1986).

Portanto, ativação da adenilato ciclase, guanilato ciclase e fosfolipase C, adaptação e desadaptação do receptor, quimiotaxia e amplificação do sinal são fenômenos intimamente ligados para coordenar a agregação das amebas induzida por cAMP. Outras respostas celulares seguem-se à estimulação por cAMP tais como fosforilação da miosina, polimerização da actina e efluxo de prótons e potássio (Janssens e Van Haastert, 1987). Além de mediar a quimiotaxia, a ativação repetida dos receptores de cAMP provoca variação no padrão de expressão gênica com a 
indução de genes essenciais para agregação como será discutido adiante. Em adição, a diferenciação das células neste organismo e a expressão gênica específica de cada tipo celular também é regulada por cAMP extracelular. Quatro genes que codificam para o receptor de cAMP (CAR) já foram identificados (Klein et al., 1988; Saxe III et al., 1991). CAR1 e CAR3 são expressos durante a agregação e parecem regular a expressão gênica durante as primeiras fases do desenvolvimento, sendo sensiveis a pulsos de cAMP. CAR1 é o responsável pela quimiotaxia e transdução de sinal nas primeiras horas de desenvolvimento. CAR3 parece ser responsável pela indução da expressão de genes de células pré-talo e pré-esporo. Todos os quatro receptores de CAMP (CAR1, CAR2, CAR3 e CAR4) são expressos durante os estágios do desenvolvimento mais tardios, após as células terem sofrido diferenciação e nesta fase eles respondem a exposição contínua de cAMP (Klein et al., 1988).

\section{3 - Características do receptor de cAMP (CAR1) que media a transdução} de sinal durante as primeiras horas de desenvolvimento

Dos diferentes receptores de CAMP expressos durante o desenvolvimento, CAR1 é o melhor caracterizado cinética e molecularmente. Este receptor foi identificado em células competentes para a agregação (Juliani e Klein, 1981) e apresenta duas formas de 40 e $43 \mathrm{kDa}$, que são interconvertidas em paralelo às oscilações de cAMP (Klein et al., 1985). A cinética e a dependência da dose de cAMP na conversão destas formas são similares às da adaptação do receptor (Devreotes e Sherring, 1985). No estado adaptado o receptor ainda liga cAMP mas não é capaz de transduzir o sinal, não ativando a adenilato ciclase, guanilato ciclase e fosfolipase C. A adaptação e a mudança da mobilidade eletroforética do receptor são correlacionadas com um aumento de 5 vezes no estado de fosforilação do receptor, sugerindo um papel para a fosforilação no mecanismo de adaptação deste (Klein et al., 1985; LubsHaukeness e Klein, 1982; Meier e Klein, 1988; Vaughan e Devreotes, 1988). A ligação de CAMP ao receptor também parece ser modulada pelo acoplamento deste às várias proteínas G, já que GTP e GDP modulam a afinidade do receptor por cAMP (Janssens e Van Haastert, 1987; Theibert e Devreotes, 1986; Van Haastert, 1984).

As características mencionadas acima tornam o sistema de sinalização quimiotática de Dictyostelium discoideum muito semelhante aos sistemas de vertebrados. Como as opsinas, os receptores adrenérgicos e outros receptores acoplados a proteínas $\mathrm{G}$, o receptor de cAMP contém multiplas regiões hidrofóbicas (Klein et al., 1988) e sugere-se que estas regiões atravessam a membrana formando 7 domínios transmembrânicos (Dohlman et al., 1987). Além disso, na sequência de 
cDNA para o receptor CAR1 é observada uma região carboxi-terminal predominantemente hidrofilica e enriquecida em resíduos de serina e treonina que seria o sítio da fosforilação induzida pelo ligante (Klein et al., 1987).

A ligação de CAMP ao receptor é heterogênea (Van Haastert e De Wit, 1984; Van Haastert et al., 1986). Cerca de $4 \%$ dos sítios liberam o cAMP ligado lentamente sendo designados de sitios $B$. Os sítios remanescentes liberam o cAMP muito rapidamente e são chamados sítios $A$. Dentro destas classes os sítios ainda são subdivididos em classes que possuem alta e baixa afinidade por CAMP, que são interconvertidas dependendo da dose e do tempo de incubação com CAMP, o que é mediado pelo acoplamento do receptor às diferentes proteínas $\mathrm{G}$. Os sítios do tipo $\mathrm{A}$ são responsáveis pela ativação da adenilato ciclase e fosfolipase $C$ e os sítios $B$ pela ativação da guanilato ciclase.

A ligação do CAMP ao receptor induz dois fenômenos diferentes: a ativação que leva à transdução do sinal e a dessensibilização. Utilizando condições que mantém constantes os niveis de cAMP (Klein, 1979; Van Haastert, 1987) foi possivel determinar a afinidade por cAMP $\left(k_{a}\right)$ dos vários componentes que participam deste processo e a meia-vida de cada um dos passos $\left(t_{1 / 2}\right)$. CAMP se liga ao receptor $e$ transduz o sinal para a adenilato ciclase com um $k_{a}$ de $5 n M$ e $t_{1 / 2}$ de 1 min. Simultâneamente, ocorre uma alteração nesta via que impede a transdução do sinal mas sem impedir a ligação do cAMP ao receptor. Este passo corresponde à adaptação do receptor, apresentando $k_{a}$ de $5 \mathrm{nM}$ e $t_{1 / 2}$ de 2-3 minutos. A adaptação é reversível quando cAMP é retirado, com um $t_{1 / 2}$ de 4 minutos. Além disso, na presença de concentrações 10 vezes maiores de cAMP, uma porção dos receptores perde a capacidade de ligar cAMP ( $k_{a}$ de $50 \mathrm{nM}, t_{1 / 2}$ de 1-4 minutos). Este fenômeno, chamado de "down-regulation", reverte muito lentamente com um $t_{1 / 2}$ de 1 hora. $A$ dessensibilização portanto, engloba 2 eventos: a adaptação e a "down-regulation" do receptor.

A "down-regulation" do receptor foi primeiramente demonstrada por Klein e Juliani, 1977 e posteriormente por Van Haastert, 1987, e definida como perda dos sítios de ligação para cAMP. Pré-incubação de células competentes para agregação com $1 \mathrm{mM}$ de cAMP por 30 minutos induz perda de cerca de $90 \%$ dos sítios de ligação para CAMP. A presença contínua do ligante é necessária para que esta perda ocorra, e $1 \mathrm{mM}$ de cAMP é suficiente para que mesmo na presença de atividade de hidrólise da fosfodiesterase, ocorra perda máxima dos sítios de ligação na membrana. No entanto, a concentração necessária de cAMP para que ocorra "down-regulation" pode ser muito menor se as células forem tratadas com DT, que inibe a 
fosfodiesterase (Pannbacker e Bravard, 1972), se um mutante de Dictyostelium que não possui fosfodiesterase for utilizado (Klein, 1979) ou se cAMP for substituido por um análogo não hidrolisável (Rossier et al., 1979). Nestas condições o ka para "downregulation" foi determinado como sendo $50 \mathrm{nM}$. Dados recentes indicam que após 30 minutos de incubação de células com $1 \mathrm{mM}$ de cAMP, os receptores permanecem na superfície celular mas são incapazes de ligar o ligante (Tao e Klein, 1990). Tratamentos mais longos com cAMP, no entanto, parecem levar à internalização e degradação do receptor (Van Haastert et al., 1992).

\section{4 - Adesão Celular durante o Desenvolvimento em Dictyostelium}

\section{discoideum.}

A comunicação célula-célula mediada por cAMP não parece ser o único modo de reconhecimento celular utilizado por Dictyostelium discoideum. Moléculas de adesão celular (CAMs) específicas encontradas em $D$. discoideum parecem também estar envolvidas no reconhecimento celular para garantia do estado multicelular atingido durante o desenvolvimento (Loomis, 1982; Devreotes, 1989). Dois tipos de sítios de adesão celular são expressos na superfície das células de $D$. discoideum no início do desenvolvimento. Um tipo de sítio de adesão é sensivel a baixas concentrações de EDTA (Gerisch, 1980). Os sítios sensiveis a EDTA (sítios de contato B) aparecem logo após iniciada a carência alimentar e estão associados com a presença de uma glicoproteína de 24000 Da (gp24) (Knecht et al., 1987). A expressão dos sítios resistentes a EDTA (sítios de contato $A, \operatorname{cs} A$ ) é induzida durante o início da agregação celular (Gerisch, 1980). A habilidade das células da fase de agregação em formar contatos resistentes a EDTA tem sido correlacionada com a presença de uma glicoproteina de 80000 daltons (gp80), que é sintetizada durante a fase de agregação e que parece mediar o contato célula-célula durante aquele período (Muller e Gerisch, 1978). A gp80 se localiza preferencialmente nas extremidades polares de células alongadas, e em filopódios que são característicos de células desta fase (Siu e Choi, 1987).

Das moléculas de adesão celular descritas em D. discoideum, a gp80 é a melhor caracterizada. Trata-se de uma proteína extensivamente modificada, através de dois tipos diferentes de glicosilação (açucares $\mathrm{N}$-ligados a asparagina e O-ligados a serina) e sulfatação (Sadeghi et al., 1987; Hohmann et al., 1987), além de possuir a âncora de glicosilfosfatidilinositol (GPI) (Sadeghi et al., 1988a; Stadler et al., 1989) que determina a associação da proteína à membrana (Sadeghi et al., 1988b; Sadeghi et al., 1987). Um único epitopo da gp80 é responsável pela adesão que é mediada pela 
porção peptídica da proteína (Siu et al., 1985; Siu et al., 1988). A adesão intercelular induzida pela gp80 é mediada por interações homofílicas (Siu et al., 1987). Um octapeptídeo localizado na porção $N$-terminal da proteína é responsável pela adesão que envolve interações iônicas seguidas de interações hidrofóbicas entre octapeptídeos de proteinas diferentes (Kamboj et al., 1989). Dados recentes confirmaram que a gp80 é responsável pelos contatos celulares da fase de agregação uma vez que a super-expressão constitutiva da gp80 leva à agregação das células durante a fase de crescimento (da Silva e Klein, 1990; Faix et al., 1990). Além disso, um mutante para gp80, obtido por disrupção gênica, apresenta a adesão resistente a EDTA extremamente reduzida quando as células são submetidas a carência sob agitação (Harloff et al., 1989). No entanto, agregação das células sobre superficie sólida não foi alterada, sugerindo que embora a gp80 seja responsável pela adesão rápida de células submetidas a agitação, um outro tipo de adesão mediado por outras moléculas deve ser suficiente para agregação de células não perturbadas mecanicamente.

A regulação da expressão da gp80 tem sido muito estudada. Tanto a proteína da superficie celular quanto os niveis de mRNA não são detectáveis em células vegetativas e atingem valores máximos em células agregadas, retornando a níveis não detectáveis durante a transformação dos agregados multicelulares no pseudoplasmódio (Noegel et al., 1986; Wong e Siu, 1986; Sadeghi et al., 1987; Siu et al., 1988). Foi proposto que o desaparecimento da proteína da superfície das células é devido a ação de uma fosfolipase que hidrolisa a âncora glicolipídica que retem a proteína na membrana (Sadeghi et al., 1988a; da Silva e Klein, 1989). No final da culminação, a proteína gp80 e o seu mRNA reaparecem, no período onde células préesporo se diferenciam em esporos. Ambos desaparecem quando as células completam o seu desenvolvimento em esporos maduros (Browne et al., 1989). A transcrição do gene para gp80 é ativada em riveis basais na fase pré-agregação e é muito aumentada por pulsos de cAMP no estágio da agregação (Noegel et al., 1986; Mann e Firtel, 1987; Siu et al., 1988; Juliani et al., 1990, este trabalho). A regulação da transcrição do gene parece ser mediada por um único elemento responsivo a cAMP (CRE) (Desbarats et al., 1992). O aumento na taxa de transcrição parece refletir a ativação de um receptor de CAMP farmacológicamente distinto do receptor quimiotático (Ma e Siu, 1990), contudo, os eventos subsequentes envolvidos não são conhecidos.

A adesão celular durante o desenvolvimento tardio pode envolver outras moléculas, já que a gp80 não é expressa durante esta fase, mas as células mantém a resistência a EDTA. Uma proteína de $95 \mathrm{kDa}$ foi postulada (mas não confirmada) como 
mediadora deste terceiro mecanismo de adesão (Steinemann e Parish, 1980). Em adição, recentemente, uma glicoproteína de $150 \mathrm{kDa}$ foi caracterizada e implicada na interação célula-célula nos estágios pós-agregação (Gao et al., 1992). Nas fases mais tardias, a adesão entre as células pré-esporo parece ser mediada por uma glicoproteína de $32 \mathrm{kDa}$ (Early et al., 1988).

\section{5 - Controle da expressão gênica em Dictyostelium discoideum}

Em Dictyostelium discoideum, o sinal externo inicial que ativa a expressão de genes regulados pelo desenvolvimento é uma combinação de falta de nutrientes e densidade celular (Marin, 1976; Chisholm et al., 1984). As células respondem à ausência de nutrientes alterando o seu padrão de biossíntese, e também monitoram a densidade celular secretando um fator durante o crescimento (Mehdy e Firtel, 1985), que lhes indica se existe um número suficiente de células para que ocorra a formação do organismo multicelular.

As mudanças na expressão gênica durante as primeiras horas de desenvolvimento (para revisão, ver Gerisch, 1987) são amplamente reguladas por pulsos de CAMP, mas existem transcritos que já são expressos durante o crescimento e têm seus niveis aumentados durante as primeiras horas de carência. Transcritos de uma outra classe são induzidos em níveis basais no início da carência e têm a sua transcrição estimulada por pulsos de cAMP. Estudos farmacológicos sugerem que os efeitos dos pulsos de cAMP na indução dos genes, durante a fase de agregação, são mediados pelo receptor de cAMP (Haribabu e Dottin, 1986; Oyama e Blumberg, 1986; Mann e Firtel, 1987; Kimmel, 1987). Aparentemente a indução destes genes é regulada por uma via de transdução de sinal que não envolve aumento nos níveis intracelulares de cAMP e sim proteina quinase C e/ou Ca2+ (Ginsburg e Kimmel, 1989; Firtel et al., 1989). Nos casos estudados, cAMP induz alteração da taxa de transcrição (Driscoll e Williams, 1987; Williams et al., 1980; Landfear et al., 1982) e adicionalmente atua na estabilização de mRNAs regulados pelo desenvolvimento (Chung et al., 1981; Mangiarotti et al., 1983). Pulsos de cAMP podem também reprimir a expressão de alguns genes, como por exemplo o inibidor da fosfodiesterase (Kessin et al., 1979).

Diferentes concentrações de cAMP extracelular induzem diferentes genes ao longo do desenvolvimento. Como descrito acima, concentrações nanomolares na forma de pulsos induzem a expressão de genes que codificam para proteínas essenciais para a agregação tais como o próprio receptor de cAMP, a adenilato ciclase, a fosfodiesterase, a proteína $G \alpha 2$, a gp80 e outros. Por outro lado, concentrações nanomolares ou micromolares constantes induzem a expressão de 
genes pré-talo, mas somente concentrações micromolares constantes são capazes de induzir a expressão de genes pré-esporo (Peters et al., 1991b). O cAMP intracelular não parece estar envolvido na diferenciação de células em células pré-esporos, mas sim na diferenciação destas células em esporos. O cAMP intracelular também parece possuir um papel na diferenciação de células pré-talo (ver a seguir).

Enquanto o cAMP extracelular está envolvido na indução da expressão de genes especificos de células pré-esporo e pela diferenciação destas em esporos, DIF (fator de indução de diferenciação) parece ser o principal responsável pela diferenciação das células pré-talo em células-talo (para uma revisão ver Williams, 1991). DIF é uma hexafenona clorada, e sendo uma molécula lipofílica parece funcionar de uma maneira análoga aos hormônios esteróides, se ligando a um receptor solúvel que age como um regulador direto da expressão gênica. DIF age como um indutor da expressão de genes específicos de células pré-talo, e um repressor em células pré-esporo (Berks e Kay, 1990). Elementos responsivos ao cAMP e DIF já foram identificados em promotores de alguns genes (Desbarats et al., 1992; Cecarelli et al., 1991).

Amônia também parece regular a expressão gênica em Dictyostelium. Durante o desenvolvimento, devido a um alto nível de catabolismo, a concentração deste composto é aumentada e parece reprimir a diferenciação de células pré-talo (Wang e Schaap, 1989). Amônia também parece levar a uma redução da concentração intracelular de cAMP (Sussman et al., 1977). Durante a culminação, os altos niveis de amônia são então reduzidos, o que leva a uma consequente elevação dos níveis de cAMP intracelular que induz a diferenciação das células pré-talo (Kwong et a!., 1988). Neste processo há também o envolvimento da proteína quinase dependente de cAMP que regula o processo de culminação, já que a super expressão da subunidade regulatória da PKA, que promove a sua inibição específica em células pré-talo, leva à formação de pseudoplasmódios que migram por períodos prolongados em condições onde normalmente a culminação seria induzida (Harwood et al., 1992).

Em resumo, o controle da expressão gênica em Dictyostelium ao longo do desenvolvimento parece ocorrer principalmente ao nivel de transcrição gênica. Alguns trabalhos apontam, no entanto, para um controle ao nivel de estabilidade de mRNAs. Certas espécies de mRNAs da fase de agregação parecem ser regulados póstranscricionalmente, uma vez que foi observado que, a disrupção dos agregados leva à desestabilização dos mRNAs, o que pode ser evitado se cAMP for adicionado às células dissociadas (Mangiarotti et al., 1985). Assim, o cAMP parece agir como um estabilizador destas mensagens, sendo o contato celular necessário para que 
concentrações locais altas de CAMP sejam mantidas. No entanto, Manrow e Jacobson (1988) contestam estes resultados afirmando que a regulação se dá a nível de transcrição. Além destes estudos, recentemente foi observado que o gene EB4-PSV é transcrito constitutivamente em células durante o crescimento e desenvolvimento mas o mRNA só se acumula quando as células formam agregados e estabelecem o padrão pré-esporo/pré-talo. Foi demonstrado que a estabilidade deste mRNA é regulada por transcrição de um mRNA complementar ("anti-sense") transcrito somente nas fases de crescimento e pré-agregação, o que leva à desestabilização da mensagem nas fases onde esta não é necessária (Hildebrandt e Nellen, 1992).

\section{6 - Objetivos}

Este trabalho teve como objetivos o isolamento e a caracterização de clones de cDNAs correspondentes a mRNAs induzidos por CAMP durante a fase de agregação que ocorre no desenvolvimento de Dictyostelium discoideum. Para tal nós analisamos clones positivos isolados por hibridização diferencial de uma biblioteca de cDNA em $\lambda$ gt10 preparada a partir de mRNAs poli $\mathrm{A}^{+}$isolados de células do mutante Agip45 pulsadas artificialmente com cAMP. Agip45 é um mutante de diferenciação celular que depende da adição exógena de pulsos de cAMP para agregar. Pulsos exógenos de cAMP induzem neste mutante o aparecimento de vários marcadores bioquimicos de diferenciação, tais como o receptor de cAMP, a fosfodiesterase, a adenilato ciclase, sítios de contato B de agregação (Juliani e Klein, 1978), e desenvolvimento normal até o estágio de agregação (Darmon et al., 1975; Juliani e Klein, 1978). Para a construção da biblioteca de cDNA, o mutante Agip45 foi submetido a carência por 8 horas na presença dos pulsos, o que estimularia a expressão de genes regulados por cAMP. A hibridização diferencial desta biblioteca com cDNAs preparados a partir de mRNAs isolados de células vegetativas e de células submetidas a carência, com ou sem a administração de pulsos de cAMP, permitiu o isolamento de clones induzidos apenas por cAMP e a eliminação de genes envolvidos somente na resposta à carência alimentar, e ainda de genes de expressão constitutiva não relacionados ao desenvolvimento. Um dos clones isolados mostrou ser regulado por cAMP, correspondendo a um mRNA que era induzido por baixas concentrações de CAMP. Por outro lado, os niveis deste mRNA eram diminuídos quando células competentes para agregação eram tratadas com altas concentrações de cAMP, que levavam à "down-regulation" do receptor de cAMP. Este efeito diferencial de cAMP, levando tanto a um aumento quanto a uma diminuição dos niveis da mensagem dependendo da sua concentração, e o fato de uma análise mais acurada deste clone 
de cDNA mostrar que este correspondia a uma proteína de adesão celular ( $\mathrm{gp80}$ ) muito estudada neste organismo, tornou o estudo da sua regulação ainda mais interessante. Este trabalho se concentrou então na elucidação das vias de transdução de sinal que eram ativadas pela "down-regulation" do receptor e na identificação dos mensageiros secundários que poderiam estar participando deste processo, levando a uma diminuição dos niveis do mRNA para gp80. 


\section{II - PROCEDIMENTO EXPERIMENTAL}

\section{1- Materiais}

\section{1 - Reagentes}

Staurosporin e o ionóforo A23187 foram obtidos da Boehringer Manheim. Pactamicina e nogalamicina foram obtidos da Upjohn Co, Kalamazoo, MI. Geneticina (G418) foi obtida da Gibco. Meios para cultura foram obtidos da Difco e Oxoid. Protossol foi obtido da New England Nuclear. RNAsin foi obtido da Promega. Os demais reagentes foram obtidos da Gibco-BRL ou Sigma.

\section{2 - Enzimas e kits}

As enzimas de restrição e modificação de DNA foram obtidas da Pharmacia, New England Biolabs, Gibco-BRL ou Promega. O kit "Prime a Gene labelling system" para marcação de sondas de DNA foi obtido da Promega.

\section{3 - Material radioativo}

Os nucleotídeos $\left[\alpha^{32} \mathrm{P}\right]$-dATP $(1000 \mathrm{Ci} / \mathrm{mmol})$ e $\left[\alpha^{32} \mathrm{P}\right]-U T P(600 \mathrm{Ci} / \mathrm{mmol})$ foram sintetizados em nosso laboratório por Mario Lopes Duarte. [ $\left.\alpha^{32} \mathrm{P}\right]$-dATP (3000 $\mathrm{Ci} / \mathrm{mmol}),\left[\alpha^{32} \mathrm{P}\right]$-dCTP $(3000 \mathrm{Ci} / \mathrm{mmol}),{ }^{125}$-proteína A $(30 \mathrm{mCi} / \mathrm{mg})$ e ${ }^{45} \mathrm{CaCl}_{2}(14,26$ $\left.\mathrm{mCi} / \mathrm{mg} \mathrm{Ca}^{2+}\right)$ foram obtidos da Amersham. ${ }^{32} \mathrm{Pi}(100 \mu \mathrm{Ci} / \mu \mathrm{l})$ foi obtido da Comissão Nacional de Energia Nuclear/SP.

\section{4 - Outros}

Membranas de nitrocelulose ou náilon foram obtidas da Amersham. Filmes de raios-X X-OMAT foram obtidos da Kodak. Intensificadores Cronex Quanta II foram obtidos da Dupont. Sephadex G-50 foi obtida da Pharmacia.

\section{2- Bactérias e vetores}

\section{1 - Cepas de E. coli utilizadas}

C600 - $F^{-}$, thi-1, thr-1, leuB6, lacY, tonA21, supE44, $\lambda$ -

JM101 - supE, thi, $\Delta$ (lac- proAB), $F^{\prime}$, traD36, proAB, lacl $Q_{Z-\Delta ~}$ M15

HB101 - supE44, hsdS20(r $\left.B^{-} m_{B}^{-}\right)$, recA13, ara-14, proA2, lacY1, galk2, rpsL20, $x y l-5, m t /-1$

\section{2 - Vetores}

igt10 - Huynh et al. (1985)

Bluescribe - Stratagene

pCytXNeoR - Pivi et al. (1993)

pSEY304 - Johnson et al. (1987)

1 G7 - Early e Williams (1988) 


\section{3 - Condições de cultivo e obtenção das células de Dictyostelium discoideum}

\section{1 - Manutenção das culturas}

Estoques de Dictyostelium discoideum da linhagem AX2 (cedida pela Dra. Claudette Klein, St. Louis University) foram cultivados em placas SM (peptona 1\%, extrato de levedura $0,1 \%, \mathrm{MgSO}_{4} \mathrm{0,1} \%$, dextrose $0,2 \%$, agar $2 \%, \mathrm{KH}_{2} \mathrm{PO}_{4} 20 \mathrm{mM} \mathrm{pH}$ 6,4 ) como descrito (Sussman, 1987). Para cada placa foram adicionados $0,2 \mathrm{ml} \mathrm{de}$ uma suspensão de bactérias Enterobacter aerogenes dissolvidas em água e uma pequena porção de corpos de frutificação maduros de Dictyostelium espalhando-se com a alça de vidro. As placas foram mantidas a $22^{\circ} \mathrm{C}$ até a formação de novos corpos de frutificação e guardadas a $4^{\circ} \mathrm{C}$ por 15 dias quando um novo estoque era refeito. Estoques de células foram mantidos também a $-80^{\circ} \mathrm{C}$. Para tal um precipitado de $5 \times 10^{7}$ células vegetativas foi ressuspenso em $2 \mathrm{ml}$ de HL-5 70\% (ver abaixo), DMSO $10 \%$ e soro fetal bovino $20 \%$, congelado em gelo seco e imediatamente armazenado a $-80^{\circ} \mathrm{C}$. Para reiniciar a cultura, estoques congelados foram descongelados na presença de uma suspensão de bactérias e espalhados em placas SM como descrito acima.

3.2 - Cultivo em meio líquido e obtenção de células competentes para agregação

Amebas de Dictyostelium discoideum da linhagem AX2 e do mutante Agip45 foram crescidas como descrito por Watts e Ashworth, 1970, em meio axênico HL-5 (proteose peptona $\mathrm{n}$-2 $1 \%$, glicose $1 \%$, extrato de levedura $0,5 \%, \mathrm{KH}_{2} \mathrm{PO}_{4} 20 \mathrm{mM} \mathrm{pH}$ 6 ,4) sob agitação de $200 \mathrm{rpm}$ a $22^{\circ} \mathrm{C}$. O desenvolvimento foi iniciado pela lavagem das células com $\mathrm{KH}_{2} \mathrm{PO}_{4} 20 \mathrm{mM}$ pH 6,4 e ressuspensão no mesmo tampão a $10^{7}$ células $/ \mathrm{ml}$. As células foram submetidas a carência sob agitação de $100 \mathrm{rpm}$ a $22^{\circ} \mathrm{C}$ (Beug et al., 1973). O monitoramento do desenvolvimento da competência para agregação foi acompanhado microscópicamente como descrito por Juliani e Klein, 1981. Em nossas condições, após 5-6 h de carência, pequenos agregados estavam formados. Agip45 não desenvolve competência para agregação quando submetido a carência, a menos que seja tratado com pulsos de $10^{-7} \mathrm{M}$ de cAMP a cada 5 minutos (Darmon et al., 1975; Darmon et al., 1977). Para tal, as células são lavadas em tampão fosfato, ressuspensas no mesmo tampão e submetidas a carência como acima por 2 horas antes da adição dos pulsos de CAMP.

\section{3 - Tratamento das células com diferentes compostos}


Células submetidas a carência por 5-6 horas foram divididas em alíquotas segundo a exigência de cada experimento e mantidas, após a adição das drogas, sob agitação de $100 \mathrm{rpm}$ a $22^{\circ} \mathrm{C}$ pelo período de incubação desejado. Nus experimentos onde A23187 ou staurosporin foram adicionados, foram feitos controles adicionando-se às células somente DMSO, que é utilizado como solvente destas drogas, e nenhuma alteração morfológica ou de viabilidade das células foi observada. Ensaios de viabilidade foram realizados diluindo-se as células após os experimentos com as drogas, plaqueando-as sobre uma camada de Enterobacter aerogenes em placas SM e contando-se, após 3 dias, as colônias de Dictyostelium formadas.

\section{4 - Transformação de Dictyostelium}

O protocolo para obtenção de transformantes estáveis foi adaptado de Nellen et al., (1987). O precipitado de DNA com cálcio foi obtido pela aplicação de 25 ou 50 $\mu \mathrm{g}$ de plasmídeo em $20 \mu \mathrm{l}$ de TE, ou $20 \mu \mathrm{l}$ de TE somente, na parede de um tubo cônico de $15 \mathrm{ml}$ contendo 0,6 ml de HBS $1 \times\left(\mathrm{NaCl} 136 \mathrm{mM}, \mathrm{KCl} 5 \mathrm{mM}, \mathrm{NaHPO}_{4}\right.$ 0,7 mM, HEPES $20 \mathrm{mM} \mathrm{pH} \mathrm{7,05,} \mathrm{dextrose} 5 \mathrm{mM}$ ). $36 \mu$ de uma solução de cálcio $2 \mathrm{M}$ foram também gotejados na parede do tubo e todo o conteúdo foi rapidamente misturado por agitação durante $10 \mathrm{~s}$.

$2 \times 10^{7}$ células da linhagem selvagem $A \times 2$, obtidas de uma cultura em fase exponencial em meio HL-5, foram adicionadas a uma placa de cultura de tecidos de 10 $\mathrm{cm}$ e deixadas para aderir por $2 \mathrm{~h}$. $\mathrm{O}$ meio foi trocado por $10 \mathrm{ml}$ de $\mathrm{HL}-5$ contendo

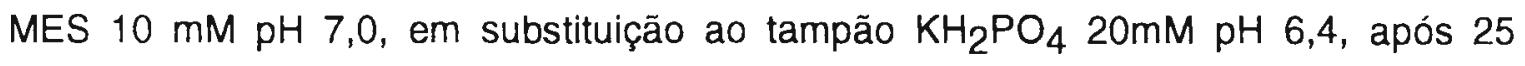
minutos removido, e o precipitado de DNA com cálcio foi gotejado no centro da placa e espalhado delicadamente. Após 25 minutos, $10 \mathrm{ml}$ de HL-5-MES foram adicionados e as placas foram mantidas imóveis por $3 \mathrm{~h}$ a $22^{\circ} \mathrm{C}$. $\mathrm{O}$ meio foi então removido e $2 \mathrm{ml}$ de glicerol $18 \%$ em HBS $1 \times$ foi adicionado. O glicerol foi delicadamente removido e $10 \mathrm{ml}$ de HL-5 contendo $250 \mu \mathrm{g} / \mathrm{ml}$ de piperacilina foram adicionados. Após incubação por uma noite, foi iniciada a seleção das células resistentes através da incubação das mesmas em $10 \mathrm{ml}$ de $\mathrm{HL}-5$ contendo $20 \mu \mathrm{g} / \mathrm{ml}$ de G418 com trocas diárias por 4 dias. Após este periodo as células foram mantidas em meio contendo $5 \mu \mathrm{g} / \mathrm{ml}$ de G418 por dois dias, $10 \mu \mathrm{g} / \mathrm{ml}$ por 1 dia e $20 \mu \mathrm{g} / \mathrm{ml}$ por mais um dia. Neste ponto várias colônias já podiam ser vistas a olho nú e as células foram ressuspensas e colocadas em frascos para crescimento em HL-5 com $20 \mu \mathrm{g} / \mathrm{ml}$ de $\mathrm{G} 418$ sob agitação a $22^{\circ} \mathrm{C}$.

\section{4 - Isolamento de RNA de Dictyostelium discoideum}

RNA total foi isolado por um método simplificado desenvolvido no laboratório da Dra. Claudette Klein (St. Louis University). Aproximadamente $10^{7}$ células foram 
coletadas por centrifugação (30 segundos em minicentrifuga), rapidamente congeladas em gelo seco, e descongeladas na presença de $400 \mu \mathrm{l}$ de fenol/clorofórmio saturado em água, $400 \mu \mathrm{l}$ de Tris-HCl $50 \mathrm{mM} \mathrm{pH} \mathrm{8,0,} \mathrm{SDS} 2 \%$ e $5 \mu \mathrm{l}$ de DEPC. As fases aquosas foram extraidas 2 vezes com fenol/clorofórmio saturado em água e uma vez com clorofórmio. O RNA foi precipitado por 30 minutos a $-20^{\circ} \mathrm{C}$ após adição de 2,2 volumes de etanol e 0,1 volumes de acetato de sódio $3 \mathrm{M} \mathrm{pH} \mathrm{4,7.} \mathrm{O} \mathrm{RNA} \mathrm{foi} \mathrm{coletado}$ por centrifugação em minicentrífuga, o precipitado foi seco a vácuo e ressuspenso em $20 \mu \mathrm{l}$ de água tratada com DEPC. Alíquotas de $1 \mu \mathrm{l}$ foram retiradas para quantificação do RNA por leitura da $A 260 \mathrm{~nm}$, onde D.O.=1 equivale a $40 \mu \mathrm{g} / \mathrm{ml}$.

\section{5 - Eletroforese de RNA em gel de agarose}

Amostras de RNA foram analisadas por eletroforese em gel de agarose 1,25\%


formaldeído $6 \%$ como descrito por Maniatis et al., 1982. A amostras de $20 \mu \mathrm{g}$ de RNA, foram adicionados 3 volumes de tampão de amostra (formamida 64,4\%, MOPS 1,3x, formaldeído 2,8\%, azul de bromofenol $0,35 \%, 50 \mu \mathrm{g} / \mathrm{ml}$ de brometo de etídeo em água tratada com DEPC). A eletroforese foi mantida a $100 \mathrm{~V}$ em tampão MOPS $1 \mathrm{x}$ contendo formaldeído $5,6 \%$ até a saída do corante e o gel foi observado em transiluminador UV.

\section{6 - Transferência de RNA para filtro de nitrocelulose ou náilon ("Northern} blot") e hibridização RNA-DNA

Após a eletroforese o gel de agarose foi lavado 2 vezes por $20 \mathrm{~min}$ com SSC 10x (SSC 1x é $\mathrm{NaCl} 150 \mathrm{mM}$, citrato trisódico $15 \mathrm{mM} \mathrm{pH} \mathrm{7,0),} \mathrm{e} \mathrm{transferido} \mathrm{para} \mathrm{filtro}$ de nitrocelulose ou náilon como descrito por Southern (1975). Após a transferência o filtro foi seco a temperatura ambiente e incubado a $80^{\circ} \mathrm{C}$ por 2 horas, no caso de membranas de nitrocelulose, ou por 6 minutos sobre luz UV no caso de náilon.

Os filtros foram prehibridizados, durante a noite a $37^{\circ} \mathrm{C}$, em formamida $50 \%$,


Antes da adição de formamida e SDS, a solução foi tratada com DEPC $1 \%$ durante a noite seguindo-se aquecimento por 1 hora a $65^{\circ} \mathrm{C}$ (Siegel e Bresnick, 1986). No dia seguinte, a sonda, purificada em coluna Sephadex G-50, foi fervida por 3 minutos e adicionada à solução $\left(10^{7} \mathrm{cpm} / \mathrm{ml}\right)$, seguindo-se hibridização por $16-24 \mathrm{~h}$ a $37^{\circ} \mathrm{C}$ sob agitação. Os filtros foram lavados por 20 minutos a temperatura ambiente em SSC 2x, SDS $0,1 \%, 20$ minutos em SSC $1 x$, SDS $0,1 \%, 20$ minutos em SSC $0, \overline{5} x$, SDS $0,1 \%$ e 
5 minutos em SSC $0,1 x$, SDS $0,1 \%$. Os filtros foram secos a temperatura ambiente e expostos a filmes de Raios- $X$ com uso de intensificadores.

Alternativamente, os filtros foram prehibridizados durante a noite a $37^{\circ} \mathrm{C} \mathrm{em}$ formamida 50\%, SSPE 6x (SSPE 20x é NaCl $3 \mathrm{M}$, NaHPO 4 0,2 M pH 7,4, EDTA 20 $\mathrm{mM}$ ), solução de Denhardt $1 \times$ (solução de Denhardt $50 x$ é Ficoll 1\%, polivinilpirrolidona $1 \%$, BSA $1 \%), 125 \mu \mathrm{g} / \mathrm{ml}$ de DNA de timo desnaturado, $25 \mu \mathrm{g} / \mathrm{ml}$ de poli(rA) desnaturado. No dia seguinte, a sonda, fervida por 3 minutos, foi adicionada à solução seguindo-se hibridização por $16-24 \mathrm{~h}$ a $37^{\circ} \mathrm{C}$ sob agitação. Os filtros foram lavados por 30 minutos a temperatura ambiente em SSC 1x, SDS 0,5\% e duas vezes por 2 horas a $52^{\circ} \mathrm{C}$ em SSC $0,1 x$, SDS $0,5 \%$. Os filtros foram secos a temperatura ambiente e expostos a filme de Raios- $X$ com uso de intensificadores.

Após exposição dos filtros de nitrocelulose ou náilon por 24 ou 48 horas os niveis de mRNA foram quantificados por densitometria dos auto-radiogramas usandose um densitômetro a laser Shimadzu CS-900. Para normalizar os niveis de mRNA aplicado em cada raia do gel os mesmos filtros foram hibridizados também com o gene $1 \mathrm{G} 7$ que corresponde a um gene expresso constitutivamente em Dictycstelium (Early e Williams, 1988). O plasmídeo contendo o gene $1 G 7$ foi gentilmente cedido pelo Dr. J. Williams (Imperial Cancer Research Fund., South Mimms, Inglaterra). Em alguns experimentos foi utilizado o cDNA da actina como controle. O plasmídeo B1 contendo este cDNA foi gentilmente cedido pelo Dr. R. Firtel (University of California, San Diego, Estados Unidos).

\section{7 - Preparação de sondas de DNA radioativas}

\section{1 - "Nick-translation"}

Sondas de cDNA radioativas foram preparadas pelo método de "nicktranslation" como descrito por Kelly et al., 1970. Para um volume de $15 \mu \mathrm{l}$ de cDNA purificado (aproximadamente $400 \mathrm{ng}$ ) foram adicionados dGTP, dCTP e dTTP para uma concentração final de $25 \mu \mathrm{M}$ cada, $50 \mu \mathrm{Ci}$ de $\left[\alpha-{ }^{32} \mathrm{P}\right] \mathrm{dATP}, 5$ uriidades de DNA polimerase I, 0,05 ng de DNAse I, em tampão Tris- $\mathrm{HCl} 50 \mathrm{mM}, \mathrm{pH} 7,2$, contendo $\mathrm{MgCl}_{2} 10 \mathrm{mM}$, DTT $1 \mathrm{mM}, \mathrm{BSA} 0,1 \mathrm{mg} / \mathrm{ml}$, sendo o volume completado com água para $25 \mu \mathrm{l}$. A incubação foi feita em banho a $14^{\circ} \mathrm{C}$ por 2 horas. A reação foi interrompida pela adição de $2 \mu \mathrm{l}$ de EDTA $0,4 \mathrm{M}$.

O DNA radioativamente marcado foi separado dos nucleotídeos não incorporados através de cromatografia em Sephadex G-50 como descrito por Maniatis et al. (1982). Os $25 \mu \mathrm{l}$ da reação foram completados para $100 \mu \mathrm{l}$ com STE (Tris-HCl 10 $\mathrm{mM} \mathrm{pH} 8,0$, EDTA $1 \mathrm{mM}, \mathrm{NaCl} \mathrm{0,1} \mathrm{M),} \mathrm{e} \mathrm{adicionados} \mathrm{ao} \mathrm{topo} \mathrm{de} \mathrm{uma} \mathrm{seringa} \mathrm{de} 1 \mathrm{ml}$ 
contendo 0,9 ml de Sephadex G-50 preequilibrada em STE. Após centrifugação por 5 minutos a $4000 \mathrm{rpm}$, alíquotas do eluato foram recolhidas para determinação da porcentagem de incorporação de $\left[\alpha^{-32}\right.$ P]dATP ao DNA, e a sonda foi armazenada a $20^{\circ} \mathrm{C}$ até sua utilizaçāo. Foram retirados $1 \mu \mathrm{l}$ da amostra da reação antes da passagem pela coluna para determinação da contagem total, $1 \mu \mathrm{l}$ da amostra antes da passagem pela coluna e $1 \mu \mathrm{l}$ da amostra da reação após passagem pela coluna, sendo que à estas duas últimas amostras foram adicionados $25 \mu \mathrm{g}$ de DNA de timo de bezerro como carreador. As amostras foram aplicadas em papel 3MM, precipitadas em TCA $10 \%$ por 15 minutos em gelo com 3 trocas (apenas no caso das duas últimas amostras), secas e contadas em contador de cintilação pelo método de Cerenkov.

\section{2 - "Random Primed Synthesis"}

Aproximadamente $60 \mathrm{ng}$ de cDNA purificado ou de plasmideo e $6 \mu \mathrm{g}$ de hexadeoxinucleotídeos foram fervidos por 2 minutos e esfriados em gelo e misturados a $100 \mu \mathrm{Ci}$ de $[\alpha-32 \mathrm{P}] \mathrm{dATP}$, dGTP, dCTP e dTTP para $10 \mu \mathrm{M}$, Tris-HCl 50mM, pH 7,2, $\mathrm{MgCl}_{2} 10 \mathrm{mM}$, DTT $1 \mathrm{mM}$, BSA $0,1 \mathrm{mg} / \mathrm{ml}$ e 6 unidades de DNA polimerase I (Klenow) como descrito por Feinberg e Vogelstein (1984). O volume foi completado com água para $50 \mu$, seguindo-se incubação a temperatura ambiente por 3 horas. A reação foi interrompida pela adição de $1 \mu \mathrm{l}$ de SDS $20 \%$ e $1 \mu \mathrm{l}$ de EDTA $0,4 \mathrm{M}$. Esta reação foi realizada com o kit "Prime a Gene labelling system" da Promega. Após a reação o DNA foi purificado através de cromatografia em Sephadex G-50 como descrito acima.

\section{8 - Isolamento de núcleos e ensaio de "run-off" nuclear}

Núcleos foram isolados como descrito por Soll e Sussman (1973). Um precipitado de $6 \times 10^{8}$ células foi ressuspenso em $3,5 \mathrm{ml}$ de tampão HEPES $50 \mathrm{mM} \mathrm{pH}$ $7,5, \mathrm{MgCl}_{2} 40 \mathrm{mM}, \mathrm{KCl} 20 \mathrm{mM}$, sacarose $13,5 \%$ gelado e incubado em gelo por 5 minutos. Foram então adicionados $1,5 \mathrm{ml}$ de Nonidet $\mathrm{P}-40$ 0,2\%, Tris- $\mathrm{HCl} 50 \mathrm{mM}$ pH $7,6, \mathrm{KCl} 25 \mathrm{mM}, \mathrm{MgCl}_{2} 40 \mathrm{mM}$, polivinil sulfato $25 \mathrm{mg} / \mathrm{ml}$ e a mistura foi agitada vigorosamente por 20 segundos, incubada por 2 minutos em gelo e centrifugada a $2000 \times \mathrm{g}$ por 10 minutos. O precipitado de núcleos foi lavado com o tampão descrito acima e ressuspenso para $6 \times 10^{7}$ núcleos $/ 100 \mu$ l neste mesmo tampão.

A transcrição "run-off" foi feita como descrita por Soll e Sussman (1973) com algumas modificações. A suspensão de $6 \times 10^{7}$ núcleos obtida como descrito acima foi incubada em 800 ul de Tris- $\mathrm{HCl} 40 \mathrm{mM}, \mathrm{pH} 7,9$, NaF $2 \mathrm{mM}, \mathrm{KCl} 5 \mathrm{mM}, \beta$ mercaptoetanol $1 \mathrm{mM},\left(\mathrm{NH}_{4}\right)_{2} \mathrm{SO}_{4} 110 \mathrm{mM}, \mathrm{MgCl}_{2} 10 \mathrm{mM}$, sacarose 3,4\%, 30 unidades de RNAsin, $0,3 \mathrm{mM}$ de cada um dos nucleotideos CTP, GTP e ATP e 200 $\mu \mathrm{Ci}$ de $\left[\alpha-{ }^{32} \mathrm{P}\right]$ UTP $(600 \mathrm{Ci} / \mathrm{mmol})$ por $60 \mathrm{~min}$ a $25^{\circ} \mathrm{C}$. O RNA foi extraído pela adição 
de $0,5 \mathrm{ml}$ de SDS $20 \%, 10 \mathrm{ml}$ de fenol/clorofórmio e $10 \mathrm{ml}$ de Tris-HCl $50 \mathrm{mM}, \mathrm{pH} 8,0$. Após homogeneização e centrifugação por 10 minutos a $10000 \mathrm{rpm}$, a fase aquosa foi extraida duas vezes com clorofórmio. O RNA foi precipitado pela adição de 0,1 volumes de $\mathrm{CH}_{3} \mathrm{COONa} 3 \mathrm{M}$ e 2,2 volumes de etanol, seguido de incubação a $-20^{\circ} \mathrm{C}$ durante uma noite. Após lavagem com etanol 70\%, seguida de centrifugação, o precipitado foi seco, ressuspenso em água tratada com DEPC e o RNA foi purificado em uma coluna de Sepharose G50. Este RNA, em geral equivalendo a $2 \times 10^{7} \mathrm{cpm}$, foi hibridizado contra $5,2,5,1$ e $0,1 \mu \mathrm{g}$ de plasmídeo imobilizado em filtros de nitrocelulose.

Para imobilizar o DNA nos filtros, $100 \mu \mathrm{g}$ de DNA do plasmideo Bluescribe, do Bluescribe contendo o cDNA da gp80 (plasmídeo B117-CAR) ou o cDNA da actina (B1) foram linearizados por digestão com $E c o R I$, desnaturados por incubação em $0,2 \mathrm{~N}$ $\mathrm{NaOH}$ a $85^{\circ} \mathrm{C}$ por 20 minutos, neutralizados com $\mathrm{HCl} 0,2 \mathrm{~N}$, ajustados para SSC $6 x$ e imobilizados em filtros de nitrocelulose por filtração em um sistema de "dot-blot". A hibridização dos filtros com $2 \times 10^{7} \mathrm{cpm}$ em solução contendo Denhardt's (descrito no item 6) foi feita por 72 horas na presença de $150 \mu \mathrm{g}$ de RNA total isolado de células vegetativas de Dictyostefium (Landfear et al.,1982).

\section{9 - Ensaio de Pulso e Caça}

Células $\left(10^{7} / \mathrm{ml}\right)$ submetidas a carência por 5 horas em MES $20 \mathrm{mM} \mathrm{pH} \mathrm{6,4,}$ $\mathrm{MgCl}_{2} 1 \mathrm{mM}$, foram incubadas com $32 \mathrm{Pi}(0,8 \mathrm{Ci} / \mathrm{ml})$ por 1,5 horas. As células foram então centrifugadas, lavadas com tampão $\mathrm{KH}_{2} \mathrm{PO}_{4} 20 \mathrm{mM} \mathrm{pH} \mathrm{6,4} \mathrm{e} \mathrm{incubadas} \mathrm{no}$ mesmo tampão à mesma densidade para iniciar a caça. Experimentos preliminares indicaram que após 45 minutos de caça nenhum aumento de radioatividade precipitável por TCA era detectado tanto no RNA total da célula (Shapiro et al., 1988), quanto no mRNA da gp80. Neste ponto, cAMP (1 $1 \mathrm{mM}$ ) foi adicionado. Alíquotas de $1 \mathrm{ml}$ foram retiradas para extração de RNA como descrito anteriormente. Uma quantidade constante de RNA marcado com ${ }^{32} \mathrm{P}(60-80 \mu \mathrm{g})$ foi aquecida a $65^{\circ} \mathrm{C}$ por 5 minutos, rapidamente esfriada em gelo e hibridizada por 72 horas contra filtros contendo DNA imobilizado. A imobilização dos plasmídeos linearizados aos filtros e as condições de hibridização e lavagem foram as descritas no ítem 8.

\section{0 - Ensaio de tomada de ${ }^{45} \mathrm{Ca}^{2+}$}

Amebas foram submetidas a carência por $5 \mathrm{~h}$ em tampão $\mathrm{KH}_{2} \mathrm{PO}_{4} 20 \mathrm{mM} \mathrm{pH}$ 6,4 , lavadas 2 vezes em HEPES $20 \mathrm{mM} \mathrm{pH} \mathrm{7,0,} \mathrm{KCl} 5 \mathrm{mM}$ e ressuspensas no mesmo tampão para $10^{8}$ células $/ \mathrm{ml}$. Seguiu-se agitação a $250 \mathrm{rpm}$ por $10 \mathrm{~min}$. Tomada de 
cálcio (como descrito por Milne e Coukell, 1991) em células controle foi iniciada pela adição de tampão HEPES $20 \mathrm{mM} \mathrm{pH} \mathrm{7,0,} \mathrm{KCl} 5 \mathrm{mM}, \mathrm{CaCl}_{2} 100$ uM e 0,5 $\mu \mathrm{Ci}{ }^{45} \mathrm{CaCl}_{2}$ a um mesmo volume de células. Em células incubadas em condições de "downregulation", a tomada foi iniciada pela adição do mesmo tampão contendo $2 \mathrm{mM}$ de cAMP. Nos tempos indicados a entrada de cálcio foi terminada pela adição de $100 \mu \mathrm{l}$ de tampão HEPES $20 \mathrm{mM} \mathrm{pH} \mathrm{7,0,} \mathrm{KCl} 5 \mathrm{mM}, \mathrm{CaCl}_{2} 775 \mathrm{mM}$ à aliquotas de $200 \mu \mathrm{l}$ de células retiradas em duplicatas. As suspensões de células foram centrifugadas imediatamente por $4 \mathrm{~s}$ e os sobrenadantes descartados. Os precipitados foram ressuspensos em $1 \mathrm{ml}$ de tampão HEPES descrito acima contendo $10 \mathrm{mM}$ de $\mathrm{CaCl}_{2}$, recentrifugados, solubilizados em $250 \mu \mathrm{l}$ de Protossol e contados em 2,5 $\mathrm{ml}$ de líquido de cintilação. Ligação não específica de cálcio foi determinada iniciando-se a incubação em tampão contendo $225 \mathrm{mM}$ de $\mathrm{CaCl}_{2}$.

\section{1 - Digestão de DNA com enzimas de restrição}

Alíquotas de $0,5 \mu \mathrm{g}$ de DNA dos plasmideos ou de $\lambda \mathrm{gt} 10$ foram digeridas por 2 horas a $37^{\circ} \mathrm{C}$ com $10 \mathrm{U}$ de uma das seguintes enzimas nos seus respectivos tampões


HindIII, Haelll, Pstl, Xhol (Tris-HCl $50 \mathrm{mM} \mathrm{pH} \mathrm{8,0,} \mathrm{MgCl} 210 \mathrm{mM}, \mathrm{NaCl} 50 \mathrm{mM}$ ), Pvull (Tris- $\mathrm{HCl} 50 \mathrm{mM} \mathrm{pH} \mathrm{7,4,} \mathrm{MgCl} 26 \mathrm{mM}, \mathrm{KCl} 50 \mathrm{mM}, \mathrm{NaCl} 50 \mathrm{mM}$ ), Sall (Tris-HCl 100 $\mathrm{mM} \mathrm{pH} \mathrm{7,6,} \mathrm{MgCl}_{2} 10 \mathrm{mM}, \mathrm{NaCl} 150 \mathrm{mM}$ ), Hincll, Hpal (Tris acetato $10 \mathrm{mM} \mathrm{pH} \mathrm{7,5,}$ $\mathrm{CH}_{3} \mathrm{COOMg} 10 \mathrm{mM}, \mathrm{CH}_{3} \mathrm{COOK} 50 \mathrm{mM}$ ) num volume final de $15 \mu \mathrm{l}$.

Para isolar em gel preparativo os insertos de CDNA clonados no vetor Bluescribe ou $\lambda$ gt 10 , aproximadamente $20 \mu \mathrm{g}$ de DNA foram digeridas por 2 horas a $37^{\circ} \mathrm{C}$ na presença de $50 \mathrm{U}$ de ECoRI, num volume final de $100 \mu \mathrm{l}$.

\section{2 - Eletroforese de DNA}

\section{1 - Gel de agarose}

Ao plasmídeo digerido adicionou-se 0,2 vezes o volume de tampão de amostra (azul de bromofenol 0,25\%, sacarose 40\%), seguindo-se eletroforese em gel de agarose 0,7\% em TBE 1x (Tris- $\mathrm{HCl} 89 \mathrm{mM}$, ácido bórico $89 \mathrm{mM}$, EDTA $2 \mathrm{mM} \mathrm{pH}$ 8,0 ) contendo $0,5 \mu \mathrm{g} / \mathrm{ml}$ de brometo de etídeo (Maniatis et al., 1982). A eletroforese foi mantida a $100 \mathrm{~V}$ em tampão de corrida TBE $1 \mathrm{x}$ até a saida do corante e o DNA foi então visualizado em transiluminador UV. O peso molecular dos fragmentos foi estimado comparando-se sua migração com a do DNA de $\lambda$ digerido com Hindlll ou com o marcador de peso molecular "1 kb DNA ladder" (BRL).

\section{2 - Gel de poliacrilamida}


O plasmídeo digerido misturado com 0,2 vezes o volume do tampão de amostra acima foi submetido a eletroforese em gel de poliacrilamida 5\% em TBE 0,5x (Maniatis et al., 1982). A eletroforese foi mantida a $100 \mathrm{~V}$ até a saída do corante e o gel foi corado após a corrida com uma solução $0,5 \mu \mathrm{g} / \mathrm{ml}$ de brometo de etídeo em água. $\mathrm{O}$ peso molecular dos fragmentos foi estimado comparando-se sua migração com a do DNA do fago $\phi \times 174$ digerido com HaellI.

\section{3 - Eluição de DNA de gel de agarose e quantificação}

\section{1 - Eluição por fenol}

Por este método (Maniatis et al., 1982) a fatia do gel de agarose contendo o fragmento de DNA foi triturada e à esta foi adicionado igual volume de fenol saturado em Tris- $\mathrm{HCl} 10 \mathrm{mM}, \mathrm{pH} 8,0$. A mistura foi congelada em gelo seco por uma hora e após o descongelamento centrifugada a $4000 \mathrm{rpm}$ por 5 minutos. Ao sobrenadante foram adicionados 0,1 volumes de $\mathrm{CH}_{3} \mathrm{COONa} 3 \mathrm{M}, \mathrm{pH} 5,4$ e 2 volumes de etanol gelado. Após precipitação em gelo seco por uma hora a mistura foi centrifugada a $10000 \mathrm{rpm}$ por 20 minutos e o sedimento ressuspenso em $200 \mu \mathrm{l}$ de TE. Seguiu-se extração com igual volume de fenol/clorofórmio e precipitação do sobrenadante com 0,1 volumes de $\mathrm{CH}_{3}$ COONa $3 \mathrm{M}, \mathrm{pH} 5,4$ e 2 volumes de etanol gelado. Após centrifugação em minicentrífuga por 15 minutos, o precipitado foi lavado com etanol $70 \%$ e ressuspenso em $20 \mu$ de TE após ser seco a vácuo.

\section{2 - Eletroeluição}

A fatia do gel contendo o inserto foi colocada dentro de um saco de diálise, imersa em tampão TBE 0,5x e submetida a voltagem constante de $100 \mathrm{~V}$ por 3 horas (Maniatis et al., 1982). O sentido da corrente foi invertido por 2 minutos, a solução contendo o DNA foi coletada do saco de diálise, transferida para um tubo tubo de minicentrífuga e o DNA precipitado pela adição de dois volumes de etanol e 1/10 do volume de $\mathrm{CH}_{3} \mathrm{COONa} 3 \mathrm{M} \mathrm{pH} \mathrm{5,4}$. Após $1 \mathrm{~h}$ de incubação em gelo seco e centrifugação por 20 minutos, o precipitado foi seco a vácuo, ressuspenso em $400 \mu \mathrm{l}$ de TE (Tris- $\mathrm{HCl} 10 \mathrm{mM}$, EDTA $1 \mathrm{mM}$ ) e extraído com o mesmo volume de fenol/clorofórmio 1:1. A fase aquosa foi novamente precipitada após adição de etanol como acima e o precipitado final ressuspenso em $20 \mu$ de TE.

\section{3 - Quantificação do DNA após a eluição}

Para a quantificação do DNA eluído de gel de agarose, uma amostra de $2 \mu \mathrm{l}$ do DNA, obtido como descrito nos ítens acima, foi submetida a eletroforese em minigel de agarose $0,7 \%$ em TBE $1 \mathrm{x}$, e as bandas de DNA dos fragmentos foram comparadas com diluições de um DNA tamanho similar e de concentração conhecida. Em alguns 
casos foi utilizado o plasmídeo pcl788/44 (gentilmente cedido pelo Dr. Francisco Gorgônio da Nóbrega) diluído sequencialmente de 200 a 5 ng por poço do gel.

\section{4 - Eluição de DNA de gel de poliacrilamida}

A fatia do gel contendo o fragmento de DNA foi triturada e o mesmo volume de tampão $\mathrm{CH}_{3} \mathrm{COONH}_{4}$ 0,5 M, $\mathrm{CH}_{3} \mathrm{COOMg} 10 \mathrm{mM}$, EDTA $1 \mathrm{mM} \mathrm{pH} \mathrm{8,0,} \mathrm{SDS} \mathrm{0,1 \%} \mathrm{foi}$ adicionado (Sambrook et al., 1989). A mistura foi incubada a $37^{\circ} \mathrm{C}$ sob agitação por uma noite e centrifugada a $10000 \mathrm{rpm}$ por 10 minutos. Ao sobrenadante foram adicionados 2 volumes de etanol e o DNA precipitado por 30 minutos em gelo. Após centrifugação por 10 minutos a $10000 \mathrm{rpm}$, o precipitado foi ressuspenso em $200 \mu \mathrm{l}$ de TE, seguindo-se nova precipitação com a adição de 2 volumes de etanol e 1/10 do volume de $\mathrm{CH}_{3} \mathrm{COONa} 3 \mathrm{M} \mathrm{pH} 5,2$. Após centrifugação o precipitado foi lavado com etanol $70 \%$, recentrifugado, seco a vácuo e ressuspenso em $10 \mu \mathrm{l}$ de TE.

\section{5 - Desfosforilação de plasmídeo linearizado}

$4 \mu \mathrm{g}$ de plasmídeo digerido foram tratados por 30 minutos com $0,1 \mathrm{U}$ de


$\mathrm{ZnCl}_{2} 0,1 \mathrm{mM}$, espermidina $1 \mathrm{mM}$. Após este intervalo mais $0,1 \mathrm{U}$ da enzima foram adicionadas e novamente seguiu-se incubação por 30 minutos. A reação foi interrompida pela adição de STE 10x para 1x (Tris- $\mathrm{HCl} 10 \mathrm{mM}$, EDTA $1 \mathrm{mM}, \mathrm{NaCl} 100$ $\mathrm{mM}$ ) e SDS para $0,5 \%$. A mistura foi aquecida por 15 minutos a $65^{\circ} \mathrm{C}$, extraída com fenol/clorofórmio e precipitada com etanol.

\section{6 - Reação de ligação de DNA}

$25 \mathrm{ng}$ de plasmídeo desfosforilado foram utilizados numa reação de ligação com 50 e $100 \mathrm{ng}$ de fragmento de DNA obtido por eluição de gel de agarose ou poliacrilamida. A ligação foi realizada na presença de $1 \cup$ de T4-DNA ligase em tampão Tris- $\mathrm{HCl} 50 \mathrm{mM} \mathrm{pH} 7,8, \mathrm{MgCl}_{2} 10 \mathrm{mM}$, DTT $10 \mathrm{mM}$, ATP $1 \mathrm{mM}$, BSA $25 \mu \mathrm{g} / \mathrm{ml}$ a $19^{\circ} \mathrm{C}$ durante a noite.

\section{7 - Preparação de bactérias competentes para transformação}

\section{1 - Método utilizando cálcio (Maniatis et al., 1982)}

Uma colônia de bactérias HB101 foi crescida a $37^{\circ} \mathrm{C}$ sob agitação durante uma noite em LB (Bacto-triptona $1 \%$, extrato de levedura 0,5\%, $\mathrm{NaCl} 0,17 \mathrm{M}$ ) e no dia seguinte a cultura foi diluida 10 vezes em LB e agitada a $37^{\circ} \mathrm{C}$ sob agitação. Ao atingir D. $0.550=0,5$, a cultura foi transferida para um banho de gelo por 10 minutos e em 
seguida centrifugada a $5000 \mathrm{rpm}$ por 5 minutos a $4^{\circ} \mathrm{C}$. O sedimento foi ressuspenso em $1 / 2$ do volume inicial em $\mathrm{CaCl}_{2} 50 \mathrm{mM}$, Tris- $\mathrm{HCl} 10 \mathrm{mM} \mathrm{pH} \mathrm{8,0} \mathrm{gelado} \mathrm{e} \mathrm{mantido}$ em gelo por 20 minutos. Após centrifugação o sedimento foi ressuspenso em 1/15 do volume inicial em $\mathrm{CaCl}_{2} 50 \mathrm{mM}$, Tris- $\mathrm{HCl} 10 \mathrm{mM} \mathrm{pH} 8,0$ gelado, e dividido em alíquotas de $200 \mu \mathrm{l}$. O volume total da reação de ligação de DNA foi adicionado às bactérias, seguindo-se incubação em gelo por 30 minutos e a $42^{\circ} \mathrm{C}$ por 2 minutos, retornando-se a mistura ao gelo por mais 2 minutos. Após a adição de $1 \mathrm{ml}$ de $L B$ as bactérias foram incubadas por 1 hora a $37^{\circ} \mathrm{C}$ e em seguida alíquotas de 200,100 e $50 \mu$ foram espalhadas sobre placas LBA (LB contendo 1,5\% agar e $100 \mu \mathrm{g} / \mathrm{ml}$ de ampicilina) que foram incubadas a $37^{\circ} \mathrm{C}$ por uma noite.

\section{2 - Método de Hanahan (1985)}

Uma colônia de E. coli JM101 foi inoculada em meio LB contendo $\mathrm{MgSO}_{4} 10$ $\mathrm{mM}$ e $\mathrm{MgCl}_{2} 10 \mathrm{mM}$. A cultura foi agitada a $37^{\circ} \mathrm{C}$ até $\mathrm{D} .0 .550=0,5$, seguindo-se incubação das bactérias por 15 minutos em banho de gelo. A suspensão foi centrifugada a $1000 \times \mathrm{g}$ por 15 minutos, o precipitado de bactérias foi ressuspenso em $1 / 3$ do volume inicial em TFB (KCL $100 \mathrm{mM}, \mathrm{MnCl}_{2} 45 \mathrm{mM}, \mathrm{CaCl}_{2} 10 \mathrm{mM}, \mathrm{HACoCl}_{3} 3$ $\mathrm{mM}, \mathrm{MES} 10 \mathrm{mM}$ pH 6,2) e mantido no gelo por 15 minutos. Uma nova centrifugação foi feita e o precipitado foi ressuspenso em 1/12,5 do volume inicial em TFB. DnD (DTT $1 \mathrm{M}$, DMSO $90 \%, \mathrm{CH}_{3}$ COOK $10 \mathrm{mM} \mathrm{pH} \mathrm{7,5)} \mathrm{foi} \mathrm{então} \mathrm{adicionado} \mathrm{para} \mathrm{3,5 \% ,} \mathrm{a} \mathrm{mistura}$ mantida em gelo por 10 minutos, seguindo-se nova adição de DnD para uma concentração final de 7\%, incubando-se em gelo por mais 15 minutos. $210 \mu$ das bactérias competentes foram adicionados ao DNA da ligação, mantidos por 40 minutos em gelo, por 90 segundos a $42^{\circ} \mathrm{C}$ e por 2 minutos em gelo. À mistura foram então adicionados $0,8 \mathrm{ml}$ de LB, seguindo-se incubação por 30 minutos a $37^{\circ} \mathrm{C}$ sob agitação moderada. Alíquotas de 400, 100 e $40 \mu \mathrm{l}$ das bactérias foram espalhadas em placas LBA às quais foram também adicionados $50 \mu \mathrm{l}$ de IPTG $100 \mathrm{mM}$ e $50 \mu \mathrm{l}$ de X-gal $2 \%$ em DMSO, e mantidas a $37^{\circ} \mathrm{C}$ durante a noite.

\section{8 - Preparação de plasmídeos}

\section{1 - Minipreparação pelo método de lise alcalina (Maniatis et al., 1982)}

Colônias de bactérias transformadas foram coletadas das placas de LBA com o auxílio de um palito, semeadas em $5 \mathrm{ml}$ de LBA e crescidas a $37^{\circ} \mathrm{C}$ por uma noite. De cada tubo, 1,5 $\mathrm{ml}$ foram transferidos para tubos de minicentrífuga e centrifugados por 1 minuto. O sedimento foi ressuspenso em $100 \mu \mathrm{l}$ de uma solução de Tris- $\mathrm{HCl} 25 \mathrm{mM} \mathrm{pH}$ 8,0 , glicose $50 \mathrm{mM}$, EDTA $10 \mathrm{mM}$ e $4 \mathrm{mg} / \mathrm{ml}$ de lisozima e incubado por 5 minutos a temperatura ambiente. A seguir foram adicionados $200 \mu$ de uma solução de $\mathrm{NaOH}$ 
0,2 N, SDS 1\%, e após homogeneização por inversão, os tubos foram incubados em gelo por 5 minutos. Foram adicionados então $150 \mu$ de uma solução gelada de $\mathrm{CH}_{3}$ COOK $3 \mathrm{M} \mathrm{pH} 4,8$ incubando-se em gelo por 5 minutos. Os tubos foram centrifugados por 5 minutos a $4^{\circ} \mathrm{C}$ em minicentrífuga, e o sobrenadante foi extraído com mesmo volume de fenol/clorofórmio 1:1. Após homogeneização e centrifugação por 2 minutos, a fase aquosa foi precipitada com 2 volumes de etanol por 5 minutos a temperatura ambiente. O precipitado foi lavado com etanol $70 \%$, recentrifugado, seco a vácuo e ressuspenso em $50 \mu \mathrm{l}$ de TE contendo RNAse para $20 \mu \mathrm{g} / \mathrm{ml}$.

\section{2 - Preparação em larga escala}

Bactérias transformadas com o plasmídeo de interesse foram crescidas em $1000 \mathrm{ml}$ de meio LBA sob agitação a $37^{\circ} \mathrm{C}$ durante a noite. No dia seguinte a cultura foi centrifugada a $4000 \mathrm{rpm}$ por 10 minutos e o precipitado foi ressuspenso em $60 \mathrm{ml}$ de glicose $50 \mathrm{mM}$, Tris- $\mathrm{HCl} 20 \mathrm{mM} \mathrm{pH} \mathrm{8,0,} \mathrm{EDTA} 10 \mathrm{mM}$ contendo $5 \mathrm{mg} / \mathrm{ml}$ de lisozima. Seguiu-se uma incubação de 10 minutos a temperatura ambiente, após a qual foram adicionados $120 \mathrm{ml}$ de $\mathrm{NaOH} 0,2 \mathrm{~N}$, SDS $1 \%$ invertendo-se o tubo gentilmente. Após incubação por 10 minutos em gelo, foram adicionados $60 \mathrm{ml}$ de $\mathrm{CH}_{3}$ COOK $5 \mathrm{M} \mathrm{pH} 4,8$ misturando-se bem. A mistura foi incubada em gelo por 20 minutos e centrifugada por 15 minutos a $6500 \mathrm{rpm}$. O sobrenadante foi filtrado em gaze para um novo tubo e em seguida foram adicionados 0,6 vezes o volume de isopropanol. Após incubação de $1 \mathrm{~h}$ a temperatura ambiente e centrifugação de 15 minutos a $8000 \mathrm{rpm}$ o isopropanol foi retirado e o tubo foi seco com papel absorvente. O precipitado foi ressuspenso em $10 \mathrm{ml}$ de $\mathrm{TE}$ e $\mathrm{CH}_{3} \mathrm{COONH}_{4}$ sólido para 2,5 $\mathrm{M}$ foi adicionado. Após incubação de 20 minutos em gelo, a solução foi centrifugada por 15 minutos a $8000 \mathrm{rmm}$ e o sobrenadante foi transferido para um novo tubo onde foram adicionados 2 volumes de etanol. Seguiu-se incubação em gelo por 20 minutos e então centrifugação por 15 minutos a $7000 \mathrm{rpm}$. O etanol foi retirado e o precipitado foi ressuspenso em $10 \mathrm{ml}$ de TE contendo RNAse para $10 \mu \mathrm{g} / \mathrm{ml}$, seguindo-se incubação por 15 minutos a $37^{\circ} \mathrm{C}$. A seguir foi adicionado $\mathrm{NaCl}$ para $1,5 \mathrm{M}$ e $1 / 4$ do volume de PEG $600030 \%, \mathrm{NaCl} 1,5 \mathrm{M}$ com incubação a $4{ }^{\circ} \mathrm{C}$ durante a noite. Após centrifugação de 15 minutos a $7500 \mathrm{rpm}$, o precipitado foi ressuspenso em $200 \mu \mathrm{l}$ de água, e foram adicionados $200 \mu \mathrm{l}$ de Tris-HCl $20 \mathrm{mM}, \mathrm{pH} 8$, EDTA $40 \mathrm{mM}$, SDS $1 \%$ contendo proteinase $\mathrm{K}$ para $500 \mu \mathrm{g} / \mathrm{ml}$. Após incubação a $37^{\circ} \mathrm{C}$ por 30 minutos, foi realizada uma extração com fenol saturado em Tris- $\mathrm{HCl} 100 \mathrm{mM}$ pH 8,0 e uma extração com fenol clorofórmio 1:1. O DNA foi precipitado em etanol na presença de $0,3 \mathrm{M}$ de $\mathrm{CH}_{3} \mathrm{COOK} \mathrm{pH} \mathrm{5,5} \mathrm{a}-20^{\circ} \mathrm{C}$ por 30 minutos e após centrifugação, lavado em 
etanol $70 \%$, ressuspenso em $200 \mu l$ de TE e quantificado por leitura da $A_{260} \mathrm{~nm}$ onde D.O.=1 equivale a $50 \mu \mathrm{g} / \mathrm{ml}$.

\section{9 - Preparação de DNA de $\lambda$ gt10}

\section{1 - Minipreparação}

Clones positivos isolados por hibridização diferencial da biblioteca de cDNA em $\lambda$ gt10 foram isolados com o auxilio de uma pipeta Pasteur e colocados em $1 \mathrm{ml}$ de tampão $\lambda$ (Tris- $\mathrm{HCl} 50 \mathrm{mM} \mathrm{pH} \mathrm{7,5,} \mathrm{NaCl} 100 \mathrm{mM}, \mathrm{MgSO}_{4} 8 \mathrm{mM}$, gelatina 0,01\%). Estes clones foram semeados utilizando-se E. coli C600 em crescimento exponencial em LBM (LB contendo $8 \mathrm{mM}$ de $\mathrm{MgSO}_{4}$ ). $\grave{A} 0,1 \mathrm{ml}$ de bactérias foram adicionados 10 $\mu l$ de cada clone de fago, incubando-se 30 minutos a $37^{\circ} \mathrm{C}$. A semeadura foi feita adicionando-se $5 \mathrm{ml}$ de LB agar $0,7 \%$ à mistura de bactérias e fagos e invertendo-os sobre placas LB. As placas foram então incubadas a $37^{\circ} \mathrm{C}$ durante a noite.

No dia seguinte as placas foram incubadas com $5 \mathrm{ml}$ de tampão $\lambda$ contendo uma gota de clorofórmio por uma hora a $37^{\circ} \mathrm{C}$ sob agitação lenta. O sobrenadante das placas foi centrifugado a $6000 \mathrm{rpm}$ por 10 minutos e foram adicionadas a $0,7 \mathrm{ml} \mathrm{da}$ suspensão de fagos DNAse I e RNAse para uma concentração final de $1 \mu \mathrm{g} / \mathrm{ml}$, seguindo-se incubação por 15 minutos a $37^{\circ} \mathrm{C}$. Após a incubação foram adicionados $0,4 \mathrm{ml}$ de PEG $600020 \%$ em NaCl 2,5 M. Esta mistura foi incubada por uma hora a $4^{\circ} \mathrm{C}$ e centrifugada em minicentrifuga por 5 minutos. O precipitado foi ressuspenso em $150 \mu$ de Tris- $\mathrm{HCl} 200 \mathrm{mM}$, EDTA $20 \mathrm{mM}$, SDS 0,3\% e $15 \mu \mathrm{l}$ de DEPC 10\% em etanol. A suspensão foi agitada vigorosamente e incubada a $37^{\circ} \mathrm{C}$ por 10 minutos. A seguir foram feitas duas extrações adicionando-se igual volume de fenol saturado em Tris$\mathrm{HCl} 0,1 \mathrm{M} \mathrm{pH} 8,0$. A suspensão foi homogeneizada, centrifugada por 5 minutos a 4000 $\mathrm{rpm}$ e a fase aquosa foi então extraída com fenol/clorofórmio 1:1. O DNA foi precipitado a $-20^{\circ} \mathrm{C}$ durante a noite após adição de $\mathrm{LiCl}$ para $0,8 \mathrm{M}$ e 2 volumes de etanol. No dia seguinte o DNA foi centrifugado por 15 minutos em minicentrífuga e $1 \mathrm{ml}$ de etanol $70 \%$ foi adicionado ao precipitado. Após uma incubação de 30 minutos em gelo seco, seguiu-se uma centrifugação de 15 minutos e o precipitado foi seco a vácuo. O DNA foi ressuspenso em $20 \mu \mathrm{l}$ de TE contendo $0,2 \mu \mathrm{g}$ de RNAse.

\section{2 - Preparação em larga escala}

E. coli C600 foi crescida por uma noite em LB a $37^{\circ} \mathrm{C}$, diluida 10 vezes, e crescida por mais 1 h. $5 \mu$ da suspensão de fagos $\lambda$ gt10 recombinantes $\left(2,5 \times 10^{6}\right.$ p.f.u.) foram adicionados a $250 \mu \mathrm{l}$ de 6600 em $5 \mathrm{ml}$ de LBM contendo glicose $0,2 \%$, agar $0,7 \%$ e espalhados sobre placas LB. Para cada clone isolado foram preparadas 10 placas em LB. As placas foram incubadas a $37^{\circ} \mathrm{C}$ por $6 \mathrm{~h}$ e esfriadas a $4^{\circ} \mathrm{C}$. A cada 
placa foram então adicionados $10 \mathrm{ml}$ de tampão $\lambda$ contendo $25 \mu \mathrm{l}$ de clorofórmio, seguindo-se incubação das placas a $4^{\circ} \mathrm{C}$ durante a noite. $O$ sobrenadante das placas foi reunido, centrifugado a $10.000 \mathrm{rpm}$ por 15 minutos a $4^{\circ} \mathrm{C}$ para sedimentação das bactérias e novamente centrifugado a $23.000 \mathrm{rpm}$ a $4^{\circ} \mathrm{C}$ por 90 minutos. O precipitado de fagos foi ressuspenso em $0,5 \mathrm{ml}$ de tampão $\lambda$, e recentrifugado em minicentrifuga por 5 segundos para remover restos celulares. $O$ sobrenadante foi então submetido a centrifugação em gradiente de densidade de $\mathrm{CsCl}$.

O primeiro gradiente de $\mathrm{CsCl}$ foi preparado colocando-se no fundo de um tubo de nitrato de celulose $1 \mathrm{ml}$ de $\mathrm{CsCl} 5 \mathrm{M}, \mathrm{MgSO}_{4} 10 \mathrm{mM}$, Tris- $\mathrm{HCl} 10 \mathrm{mM} \mathrm{pH} \mathrm{8,0}$, EDTA $0,1 \mathrm{mM}$, e sobre este $3 \mathrm{ml}$ da mesma solução contendo $\mathrm{CsCl}$ para $3 \mathrm{M}$. Sobre este gradiente descontínuo foi aplicado $0,5 \mathrm{ml}$ da solução de fagos acima seguindo-se centrifugação a $30.000 \mathrm{rpm}$ em rotor SW 27.1 por 1 hora a $20^{\circ} \mathrm{C}$. A banda correspondente aos fagos foi coletada com o auxilio de uma seringa com agulha inserida na lateral do tubo, removendo-se $0,5 \mathrm{ml}$ da região de interface das duas concentrações de $\mathrm{CsCl}$. Esta amostra foi depositada no fundo de outro tubo de nitrato de celulose, $0,5 \mathrm{ml}$ de $\mathrm{CsCl} 7,2 \mathrm{M}, \mathrm{MgSO}_{4} 10 \mathrm{mM}$, Tris-HCl $10 \mathrm{mM} \mathrm{pH} \mathrm{8,0,} \mathrm{EDTA} \mathrm{0,1}$ $\mathrm{mM}$ foram adicionados e sobre este foram aplicados $3 \mathrm{ml}$ da solução $5 \mathrm{M}$ de $\mathrm{CsCl}$ e 1 $\mathrm{ml}$ da solução $3 \mathrm{M}$ de $\mathrm{CsCl}$ como acima. Os tubos foram novamente centrifugados a $30.000 \mathrm{rpm}$ por $1 \mathrm{~h}$ a $20^{\circ} \mathrm{C}$ e $0,5 \mathrm{ml}$ da banda correspondente aos fagos foi coletado como descrito acima.

O $\mathrm{CsCl}$ foi removido da amostra, através de diálise contra 1.000 vezes 0 volume em Tris- $\mathrm{HCl} 50 \mathrm{mM}$ pH 8,0, $\mathrm{NaCl} 10 \mathrm{mM} \mathrm{e} \mathrm{MgCl}_{2} 10 \mathrm{mM}$, por 2 horas com uma troca. A suspensão de fagos foi transferida para um tubo onde foram adicionados EDTA pH 8,0 para $20 \mathrm{mM}$, pronase para $0,5 \mathrm{mg} / \mathrm{ml}$ e SDS para $0,5 \%$, incubando-se por $1 \mathrm{~h}$ a $37^{\circ} \mathrm{C}$. A mistura foi extraida com igual volume de fenol (equilibrado em Tris$\mathrm{HCl} 100 \mathrm{mM} \mathrm{pH} \mathrm{8,0),} \mathrm{centrifugada} \mathrm{por} 5$ minutos a $1600 \times \mathrm{g}$, e a fase aquosa novamente extraída com igual volume de fenol/clorofórmio $1: 1$ e igual volume de clorofórmio, centrifugando-se como acima. A fase aquosa resultante foi então dialisada contra 1.000 vezes o volume de TE a $4^{\circ} \mathrm{C}$ por uma noite e o DNA purificado armazenado a $-20^{\circ} \mathrm{C}$.

\section{0 - Eletroforese de proteínas em gel de poliacrilamida contendo SDS} (SDS-PAGE)

A eletroforese de proteínas foi feita como descrito por Laemmli (1970) com gel de separação de $10 \%$ de poliacrilamida e gel de empilhamento de $4,5 \%$. Um sedimento de $2 \times 10^{6}$ células foi dissolvido em $70 \mu$ de tampão de amostra Tris-HCl 50 
$\mathrm{mM} \mathrm{pH} \mathrm{6,8,} \mathrm{DTT} 25 \mathrm{mM}$, glicerol 10\%, SDS $1 \%$ e $0,08 \mathrm{mg} / \mathrm{ml}$ de azul de bromofenol. As amostras foram fervidas por $2 \mathrm{~min}$ e $1 \mu \mathrm{l}$ de DTT $1 \mathrm{M}$ foi adicionado. $35 \mu \mathrm{l}$ de cada amostra ( $1 \times 10^{6}$ células) foi aplicado no gel. A corrida foi desenvolvida a $30 \mathrm{~mA}$ ou 175 $V$ até a saida do corante.

21 - Transferência eletroforética de proteínas de géis de poliacrilamida para filtros de nitrocelulose ("Western blot") e detecção imunológica das proteínas

Após separação das proteínas por eletroforese em gel de poliacrilamida/SDS, as mesmas foram submetidas a transferência eletroforética para filtro de nitrocelulose pelo método semi-seco como descrito por Harlow e Lane (1988). Quando necessário o filtro foi corado com Ponceau $0,1 \%$ em ácido acético $10 \%$ e descorado por lavagem com água. Em seguida o filtro de nitrocelulose foi incubado por 30 minutos a temperatura ambiente, sob agitação lenta, em TBS (Tris-HCl $10 \mathrm{mM} \mathrm{pH} \mathrm{7,4,} \mathrm{NaCl} 150$ $\mathrm{mM}$, azida $0,02 \%$ ) contendo $5 \%$ de leite em pó desnatado e por uma noite com o anticorpo policlonal de coelho contra gp80 diluido 1:200 nesta solução. Após lavagem por 30 minutos com várias trocas de TBS, o filtro foi incubado por $2 \mathrm{~h}$ com 125 . proteína $A\left(10^{6} \mathrm{cpm} / \mathrm{ml}\right)$ em TBS contendo $5 \%$ de leite em pó desnatado a temperatura ambiente. $O$ filtro foi lavado por 1 hora com várias trocas de TBS, seco e exposto a filme de raios- $X$. 


\section{III - RESULTADOS}

1 - Isolamento e caracterização de um gene regulado por cAMP em Dictyostelium discoídeum

A biblioteca de cDNA foi construída e analisada pela Dra. M. H. Juliani em colaboração com a Dra. C. Klein, na St. Louis University, EUA. Clones recombinantes de $\lambda$ gt10 contendo cDNAs correspondentes a genes induzidos por cAMP foram isolados após hibridização diferencial da biblioteca contra cDNAs preparados a partir de mRNAs isolados de células estimuladas ou não com cAMP, e de células vegetativas.

1.1 - Análise dos clones positivos isolados da biblioteca de cDNA do mutante Agip45

Da biblioteca de cDNA do mutante Agip45 foram isolados 32 clones que apresentaram sinal positivo apenas quando hibridizados com cDNAs de células pulsadas com cAMP (ver introdução, ítem 6). O DNA de $\lambda$ gt10 dos clones foi purificado por minipreparações e submetido a digestão com a enzima $E c o R /$ que libera o inserto. Os DNAs digeridos foram analisados por eletroforese em gel de agarose e os pesos moleculares dos 7 clones que apresentaram inserto foram estimados comparando-se com DNA de $\lambda$ digerido com HindIII (tabela I).

Uma preparação em larga escala de DNA de $\lambda$ gt10 dos 7 clones listados na Tabela I foi realizada, e o seu DNA foi digerido com EcoR/. Após eletroforese em gel de agarose, o DNA correspondente aos insertos foi eletroeluido do gel, quantificado e subclonado no vetor Bluescribe para facilitar o posterior isolamento dos cDNAs em maior escala e permitir o seu sequenciamento.

Para confirmação de que estes clones de cDNA correspondiam a mRNAs cuja expressão era regulada por CAMP, os insertos, agora clonados no vetor Bluescribe, foram purificados e utilizados como sonda na análise de "Northern blots" do mutante Agip45. RNA do mutante Agip45 foi extraído, utilizando-se células vegetativas e células submetidas a carência por 8 horas, na presença ou ausência de pulsos de CAMP. Estes RNAs foram submetidos a eletroforese em gel de agarose contendo formaldeído, transferidos para filtros de nitrocelulose e hibridizados contra as sondas preparadas a partir dos clones listados na tabela I. Na fig. 3 podemos observar que apenas o clone 41 correspondia a um mRNA cuja expressão era fortemente estimulada por cAMP e que todos os outros eram falsos positivos. O mRNA que ribridizou com o clone 41 apresentou um tamanho estimado de 1,8 kb, que foi calculado comparando-se com o peso molecular dos RNAs ribossomais. 
TABELA I - Estimativa do peso molecular dos cDNAs dos clones positivos

\begin{tabular}{|c|c|}
\hline clone & $\begin{array}{c}\text { peso molecular } \\
\text { (kb) }\end{array}$ \\
\hline 15 & 1,0 \\
29 & 0,9 \\
32 & 1,1 \\
41 & 1,5 \\
56 & 0,8 \\
305 & 0,6 \\
336 & 1,0 \\
\hline
\end{tabular}

\section{2 - Caracterização do clone 41}

A caracterização inicial do clone 41 foi feita pela sua digestão com várias enzimas de restrição. Após eletroforese em gel de agarose (dados não mostrados), analisamos os pesos moleculares dos fragmentos obtidos após digestão com EcoRl, HindlII, Bglll, BamHI, Pstl, Pvull, Xhol, Haelll, Hincll e Accl. A fig. 4 apresenta um mapa simplificado contendo somente os sítios de restrição únicos encontrados. $O$ clone 41 não possui sítios para BamHI, Pstl e Xhol.

A análise do mapa de restrição do cDNA do clone 41 revelou que este era extremamente semelhante a um clone de cDNA (clone 117) isolado no laboratório da Dra. C. Klein (fig. 4), e que correspondia ao antígeno 117, uma glicoproteína de 70-72 kDa envolvida na adesão celular que ocorre na fase de agregação (Browne et al., 1989). O sequenciamento parcial do cDNA de $1,5 \mathrm{~Kb}$ do clone 41 (A. M. da Silva e C. Klein, resultados não publicados) confirmou que este cDNA era muito semelhante ao cDNA de $1,6 \mathrm{~Kb}$ do clone 117 , não possuindo, no entanto, aproximadamente $200 \mathrm{pb}$ da região $5^{\prime}$ terminal. Como o clone 117 , por outro lado, era incompleto na região $3^{\prime}$ terminal, um cDNA completo de $1,7 \mathrm{~kb}$ foi construído (A. M. da Silva e C. Klein, resultados não publicados) pela substituição da região $5^{\prime}$ do cDNA do clone 41 pela região $5^{\prime}$ do cDNA do clone 117. A região $5^{\prime}$ do clone 117 corresponde a 558 pb ou seja, o fragmento entre o sítio de clonagem EcoRl e o sítio Accl presente no cDNA. Este clone de cDNA completo foi chamado B117- $\mathrm{CAR}$. A sequência codificadora deste cDNA corresponde exatamente às sequências previamente publicadas para o cDNA de uma proteína de adesão celular conhecida como gp80 (Noegel et al., 1986; Siu et al., 1987), contudo o cDNA B117'-CAR contém 59 bases a menos na região $5^{\prime}$ terminal. 


$$
V \text { C P }
$$

15


41
56

$V C P$


Fig. 3 - Auto-radiografia de "Northem blots" contendo RNA total isolado do mutante Agip45. Células vegetativas (V), células submetidas a carência por 8 horas na ausência $(C)$ ou presença de pulsos de cAMP $(P)$. Os filtros foram hibridizados contra sondas radioativamente marcadas por "Nick-translation" de cDNAs dos clones indicados na figura. A equivalência da quantidade de RNA aplicada em cada poço foi verificada por coloração do gel com brometo de etideo. 




clone 117



clone 41

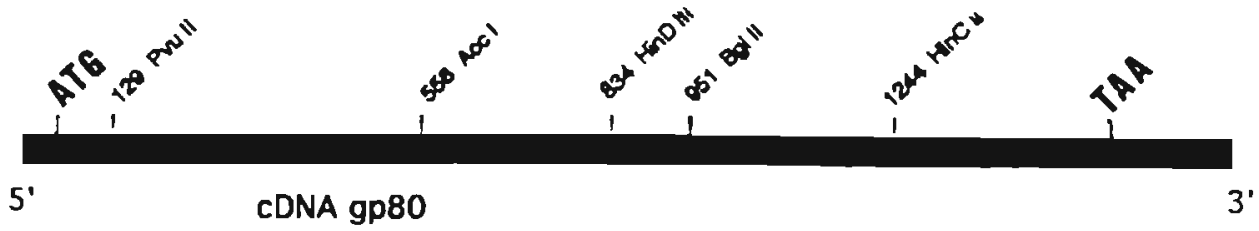

Fig. 4 - Mapa de restrição simplificado do cDNA para gp80 indicando apenas os sítios únicos correspondentes às enzimas indicadas. Também indicados estão os cDNAs dos clones 41 e 117 que foram utilizados para construir o cDNA completo da gp80 como indicado no texto. 
Análises bioquímicas adicionais confirmaram que o antígeno 117 correspondia à proteína de adesão celular gp80 de $80 \mathrm{kDa}$, responsável pelos sítios de contato $\mathrm{A}$ de adesão celular independente de cálcio, e que as diferenças de peso molecular observadas entre as duas proteínas eram devidas a diferenças entre as linhagens de Dictyostelium utilizadas em diferentes laboratórios (da Silva e Klein, 1990). O clone de cDNA B117-CAR será, portanto, referido no restante deste trabalho como clone de cDNA para gp80 (fig. 4).

\section{2 - Estudo da regulação da expressão do mRNA para gp80 em resposta ao CAMP}

Para estudarmos a regulação da expressão do mANA para gp80 foram realizados os experimentos descritos a seguir, onde RNA de células submetidas aos diversos tratamentos foi extraído, transferido para filtro de nitrocelulose, e hibridizado com a sonda do CDNA para gp80. Este cDNA foi obtido pela digestão por EcoR/ do clone B117 CAR, purificado de gel de agarose e marcado por "Random Primed Synthesis" com $[\alpha-32 \mathrm{P}$-dATP] e [ $\alpha-32 \mathrm{P}$-dCTP].

\section{1- Efeito de pulsos de cAMP na expressão do mRNA para gp80}

Para examinar os efeitos de pulsos de cAMP nos niveis de mRNA para gp80, utilizamos o mutante de agregação Agip45. Como estas células não são capazes de sintetizar pulsos de cAMP quando submetidas a condições de carência nutricional, foi possível examinar o efeito de pulsos exógenos de cAMP na expressão do gene para gp80. Quando células de Agip45 foram submetidas a carência na ausência de pulsos de cAMP, nenhum mRNA foi detectado (fig. 5A, raias 1-4) exceto após 8 horas de carência (raia 5) quando nota-se niveis de expressão basal independente de pulsos de cAMP deste mRNA (Siu et al., 1988). Por outro lado, quando a estas células foram aplicados pulsos de cAMP $\left(10^{-7} \mathrm{M}\right.$ a cada 5 minutos), 2 horas de tratamento já foram suficientes para induzir o aparecimento do mRNA para gp80 (raia 6). Como o tratamento com pulsos só é iniciado após 2 horas de carência, 2 horas de tratamento correspondem a um total de 4 horas de carência. Níveis máximos de mRNA para gp80 foram observados após 6 horas do tratamento com pulsos (raia 8) o que corresponde a 8 horas de carência. $O$ aparecimento de mRNA para gp80 no mutante Agip45 pulsado ao longo do tempo é semelhante ao selvagem $A X 2$, no qual pulsos de cAMP são espontâneamente gerados (fig. 5B).

Apesar destes resultados indicarem que os níveis de mRNA para gp80 são rapidamente induzidos por pulsos de cAMP, esta indução poderia corresponder a um efeito indireto do cAMP como por exemplo, um aumento do cAMP intracelular que 
ocorre, nestas condições, pela ligação de cAMP ao receptor. Ainda poderíamos esperar que a expressão de qualquer componente regulado pelo desenvolvimento, aumentada neste período, fosse inicialmente responsável pela indução da expressão do mRNA para gp80. Nós investigamos então o envolvimento de cAMP intracelular na indução do aumento dos níveis de mRNA para gp80 na linhagem selvagem AX2. Isto foi explorado submetendo-se células a carência na presença de $5 \mathrm{mM}$ de cafeína, que em Dictyostelium inibe a ativação da adenilato ciclase, portanto inibindo mudanças nos niveis de CAMP intracelular (Mann e Firtel, 1987; Kimmel, 1987; Brenner e Thomas, 1984). Na fig. 6 podemos observar que células $A X 2$ submetidas a carência na presença de cafeína não apresentaram aumento dos níveis de mRNA para gp80 ao longo deste periodo (raias 1-4 e 14). Como células submetidas a carência na presença de cafeína não são capazes de sintetizar cAMP, elas não são capazes de produzir pulsos extemos deste nucleotídeo. Quando às células tratadas com cafeína aplicamos pulsos exógenos de cAMP, niveis significantes de mRNA foram induzidos (raias 1013). As raias 5-9 mostram os niveis de mRNA em células pulsadas com cAMP na ausência de cafeína. Estes dados sugerem que, aumento nos niveis intracelulares de CAMP não é diretamente responsável pela indução do aumento nos niveis de mRNA para gp80 pelos pulsos de cAMP. Evidências de que a indução do mRNA da gp80 é consequência direta da ligação de cAMP ao seu receptor serão discutidas posteriormente.

\section{2 - Efeito de concentrações altas e constantes de cAMP nos níveis do} mRNA para gp80

Uma vez que células competentes para agregação estimuladas com $1 \mathrm{mM}$ de CAMP apresentam rápida "down-regulation" do receptor de CAMP, de tal modo que após 30 minutos de tratamento ocorre perda de $80-85 \%$ dos sítios de ligação (Klein e Juliani, 1977), decidimos examinar o efeito deste tratamento nos niveis do mRNA para gp80. Como pode ser visto na fig. 7 (raias 1, 3, 5, 7, 9 e 10), células da linhagem AX2 submetidas a carência por 6 horas, e portanto competentes para agregação, quando tratadas com $1 \mathrm{mM}$ de cAMP apresentaram uma significativa diminuição dos niveis de mRNA para gp80. Após 30 minutos de tratamento foram detectados apenas $10 \%$ da mensagem em relação ao controle não tratado (comparar raias 6 e 7). O mesmo filtro foi hibridizado contra o cDNA da actina e os niveis do mRNA correspondente não mostraram nenhuma variação em resposta ao tratamento com cAMP (dados não mostrados).

Para investigarmos se o efeito do tratamento com altas concentrações de cAMP nos niveis de mRNA para gp80 resultavam da "down-regulation" do receptor, 




Fig. 5 - (A) Auto-radiografia de "Northern blot" contendo RNA total de células do mutante Agip45 submetidas a carência por 2 horas e então puisadas (raias 6-8) ou não (raias $1-5$ ) com $10^{-7} \mathrm{M}$ de cAMP a cada 5 minutos. Os tempos de carência são de 0 horas (1), 2 horas (2), 4 horas ( 3 e 6), 6 horas ( 4 e 7), 8 horas (5 e 8). (B) Autoradiografia de "Northern Blot" contendo RNA total de células da linhagem selvagem AX2 submetidas a carência por 2 horas (1), 4 horas (2), 6 horas (3) e 8 horas (4). Os filtros foram hibridizados contra sonda correspondente ao cDNA da gp80. O filtro em $A$ foi super-exposto para confirmar a ausência de mRNA para gp80 quando pulsos de cAMP não foram adicionados. A equivalência da quantidade de RNA aplicada em cada poço foi verificada por coloração do gel com brometo de etídeo. 


\section{$\begin{array}{llllllllllllll}1 & 2 & 3 & 4 & 5 & 6 & 7 & 8 & 9 & 10 & 11 & 12 & 13 & 14\end{array}$}

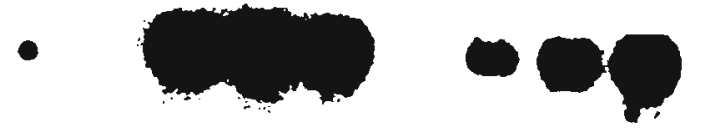

Fig. 6 - Auto-radiografia de "Northern blot" contendo RNA total de células AX2 submetidas a carência na presença de cafeína, adicionada inicialmente para $5 \mathrm{mM}$ e a cada hora para $2 \mathrm{mM}$ (1-4 e 14). Após 2 horas de carência metade das células foi pulsada com cAMP (5-9) ou pulsada com cAMP na presença de cafeina (10-13). Os tempos de carência são 0 horas (5), 2 horas (1, 6 e 10), 4 horas (2, 7 e 11), 6 horas (3, 8 e 12) e 8 horas $(4,9,13$ e 14). O filtro foi hibridizado contra sonda correspondente ao cDNA da gp80. A equivalência da quantidade de RNA aplicada em cada poço foi verificada por coloração do gel com brometo de etídeo. 
experimentos similares foram feitos utilizando-se análogos de cAMP em três concentrações (1, 0,1 e 0,01 mM). 2'-desoxi-cAMP é um agonista potente para o receptor de cAMP da superficie celular, mas um fraco ativador da proteína quinase dependente de cAMP. Dibutiril-CAMP tem características opostas (Van Haastert e Kien, 1983; Oyama e Blumberg, 1986). Como mostrado na fig. 8 (raias 1-3), tratamento das células com dibutiril-cAMP, nas concentrações testadas teve pouco ou nenhum efeito nos niveis de mRNA para gp80. Em contraste, tratamento com 2'-deoxi-cAMP (raias 79) resultou numa grande diminuição dos niveis da mensāgem, com uma dependência de concentração semelhante à observada com cAMP (raias 4-6). Os resultados indicam que os efeitos de concentrações altas de cAMP no mRNA para gp80 são mediados pelo receptor de cAMP da superfície da célula.

2.3 - Análise do nível molecular em que a "down-regulation" do receptor induz a diminuição nos níveis do mRNA para gp80

Para determinarmos se a diminuição dos niveis de mRNA para gp80 induzida por concentrações altas de cAMP era devida a uma diminuição dos níveis de transcrição do gene fizemos ensaios de "run-off" nuclear. Nestes experimentos foram comparados os niveis de transcrição em núcleos isolados de células submetidas a carência por 6 horas e incubadas por 30 minutos na presença ou ausência de $1 \mathrm{mM}$ de CAMP. Na fig. 9 podemos observar que não ocorre diminuição dos níveis de transcrição do gene da gp80 em núcleos de células tratadas com $1 \mathrm{mM}$ de cAMP. Como esperado, tais núcleos sintetizaram quantidades equivalentes de mRNA para actina, um gene que não é afetado por cAMP (Kimmel e Firtel, 1982). Núcleos isolados de células vegetativas não sintetizaram níveis detectáveis de mRNA para gp80, em concordância com o fato de células vegetativas de Dictyostelium não acumularem niveis detectáveis de mRNA para gp80. Portanto, o aumento ao longo do desenvolvimento dos niveis de mRNA para gp80 reflete a ativação da transcrição do gene para gp80, mas a diminuição dos níveis de mRNA quando as células são tratadas com altas concentrações de cAMP deve, provavelmente, ser devida a um aumento na degradação da mensagem.

Esta hipótese foi confirmada ao determinarmos a estabilidade do mRNA para gp80 no ensaio de pulso e caça, onde células submetidas a carência foram marcadas com ${ }^{32} \mathrm{PO}_{4}$ por 1,5 horas (pulso) e então incubadas em tampão $\mathrm{KH}_{2} \mathrm{PO}_{4} 20 \mathrm{mM} \mathrm{pH}$ 6,4 por 45 minutos (caça). Neste ponto, metade das células foi estimulada com $1 \mathrm{mM}$ de CAMP e após diferentes tempos da adição de cAMP, amostras foram tomadas para determinação dos niveis de mRNA radioativo para gp80 por hibridização contra o cDNA da gp80. Como mostrado na fig. 10, células que foram tratadas com cAMP 


\section{$\begin{array}{llllllllll}1 & 2 & 3 & 4 & 5 & 6 & 7 & 8 & 9 & 10\end{array}$}

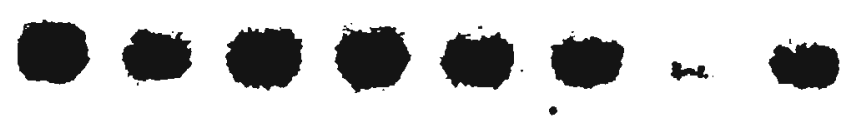

Fig. 7 - Auto-radiografia de "Northern blot" contendo RNA total de células AX2 submetidas a carência por 6 horas quando metade das células foi estimulada com CAMP para $1 \mathrm{mM}$ pelos seguintes tempos: 1 minuto (1), 5 minutos (3), 15 minutos (5), 30 minutos (7), 45 minutos (9) e 60 minutos (10). As raias 2, 4, 6 e 8 representam os niveis de mRNA de células que não foram tratadas com cAMP mas incubadas pelos 545 minutos adicionais. $O$ filtro foi hibridizado contra sonda correspondente ao CDNA da gp80. A equivalência da quantidade de RNA aplicada em cada poço foi verificada por coloração do gel com brometo de etídeo. 


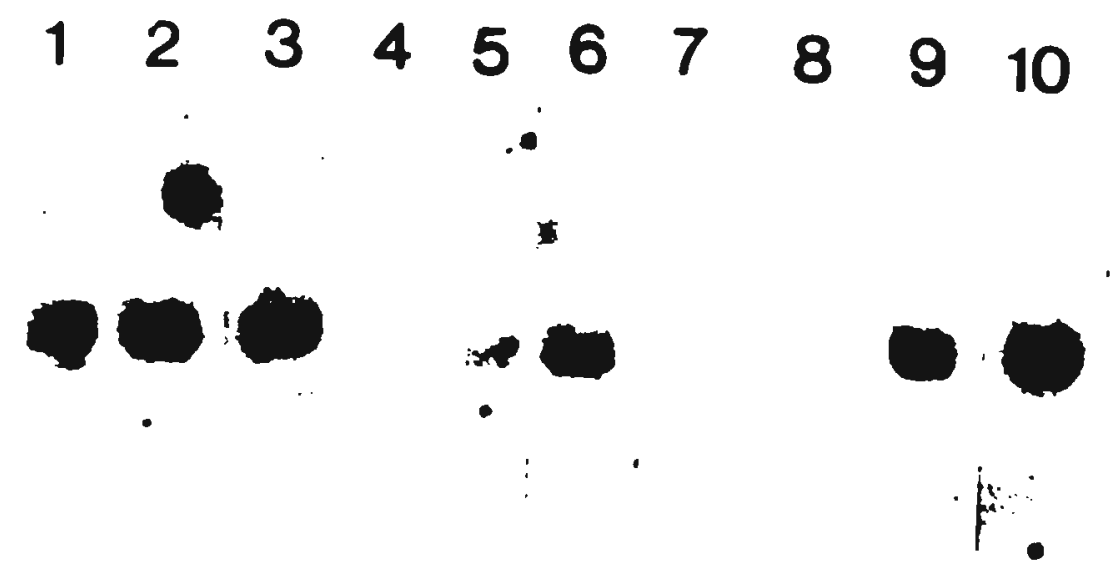

Fig. 8 - Auto-radiografia de "Northem blot" contendo RNA total de células AX2 submetidas a carência por 6 horas quando CAMP, 2'-deoxi-cAMP ou dibutiri-cAMP foi adicionado, seguindo-se incubação por 30 minutos adicionais. (1-3) tratamento com 1 , 0,1 ou $0,01 \mathrm{mM}$ de dibutiril-cAMP respectivamente. (4-6) tratamento com as mesmas concentrações de cAMP. (7-9) tratamento com as mesmas concentrações de 2'-deoxiCAMP. (10) células incubadas por 30 minutos sem adição dos compostos. O filtro foi hibridizado contra sonda correspondente ao cDNA da gp80. A equivalência da quantidade de RNA aplicada em cada poço foi verificada por coloração do gel com brometo de etídeo. 


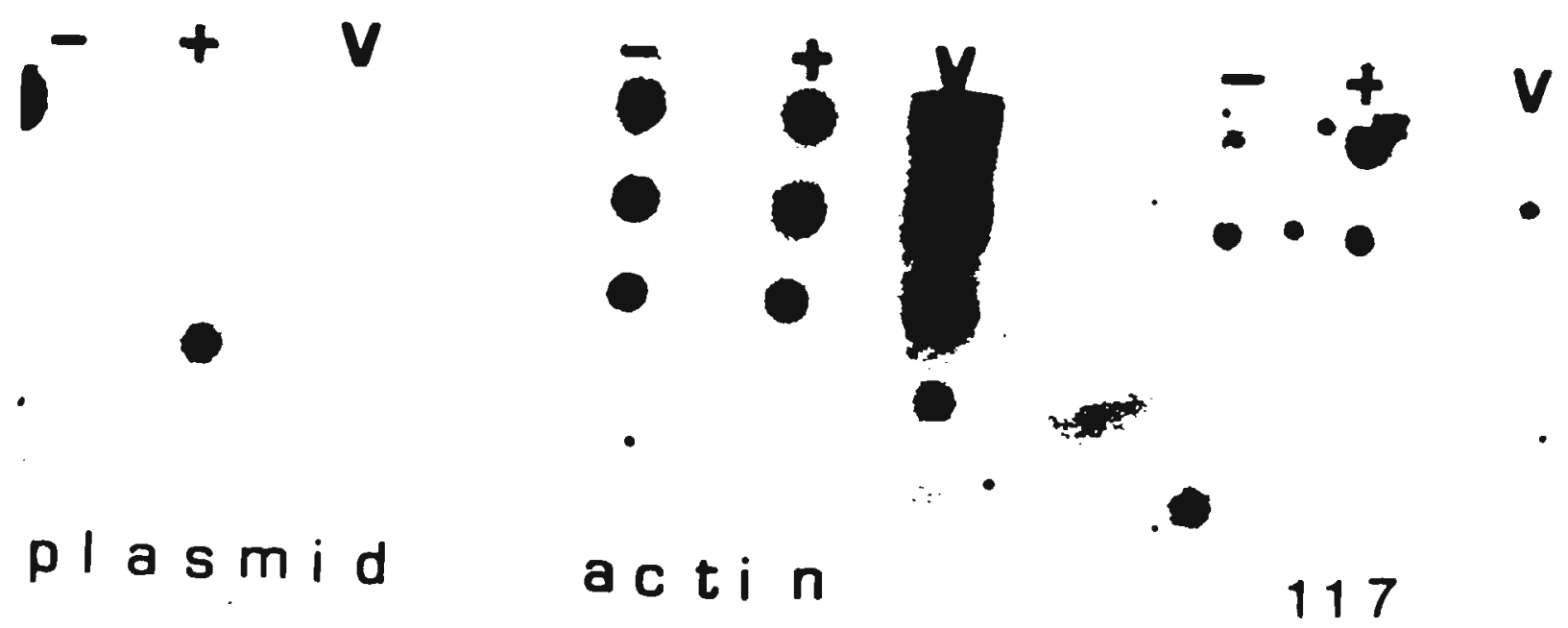

Fig. 9 - Auto-radiografia de "dot-blots" contendo o plasmideo Bluescribe sem inserto, ou contendo inserto para o cDNA da actina ou gp80. De cima para baixo as quantidades de DNA imobilizadas nos filtros são 5, 2,5,0,1,0,01, e 0,005 $\mu \mathrm{g}$. Células foram submetidas a carência por 6 horas e incubadas na presença (+) ou ausência (-) de $1 \mathrm{mM}$ de cAMP por 30 minutos. Neste ponto núcleos foram isolados e submetidos a um ensaio de "run-off" nuclear. Núcleos de células vegetativas também foram analisados (V). Os filtros foram hibridizados contra o RNA extraído dos núcleos. 
apresentam uma degradação acelerada do mRNA para gp80 quando comparada com o controle não tratado. Na ausência de tratamento com CAMP, apenas uma leve diminuição de mRNA radioativo para gp80 foi observada durante os 60 minutos de incubação. Em contraste, este nível foi dramaticamente reduzido nas células estimuladas com cAMP. Nos primeiros 15 minutos de incubação das células com CAMP, a diminuição dos niveis do mRNA para gp80 foi pequena, seguida de uma maior perda nos 15 minutos subsequentes. Após este periodo apenas leve diminuição dos niveis do mRNA foi observada. A desestabilização verificada para o mRNA da gp80, após incubação das células com cAMP, não é um fenômeno generalizado. Os niveis de mRNA radioativo para actina permaneceram relativamente constantes durante o período de caça, como anteriormente reportado (Shapiro et al., 1988), e não foramı afetados por estimulação das células com cAMP (dados não mostrados).

Em resumo, o conjunto de resultados obtidos até aqui indicam que estimulação de células competentes para agregação com $1 \mathrm{mM}$ de cAMP induz um aumento na degradação do mRNA para gp80. Para determinarmos se este é um efeito primário ou se requer síntese de uma nova proteína (efeito secundário), nós examinamos a estabilidade do mRNA em células tratadas com inibidores de síntese de RNA e de proteína. Inibição de síntese de RNA foi realizada utilizando-se uma mistura de actinomicina $D$ e daunomicina, que é capaz de inibir completamente a transcrição via RNA polimerase II (Chung et al., 1981). A fig. 11A mostra que praticamente não se verificou diminuição dos niveis de mRNA para gp80 na presença de $1 \mathrm{mM}$ de cAMP quando síntese de mRNA foi inibida. Para eliminar a possibilidade destes inibidores estarem estabilizando a mensagem, nós também realizamos estes experimentos na presença de nogalamicina. Este inibidor de sintese de RNA foi utilizado em Dictyostelium para determinar a meia-vida de mRNA durante a germinação de esporos (Kelly et al., 1985). Como mostra a fig. 11B, nogalamicina também previniu a degradação do mRNA para gp80.

A incapacidade da estimulação com cAMP induzir desestabilização do mRNA para gp80 nos experimentos descritos acima sugere que síntese de RNA é necessária para que isto ocorra. Um RNA sintetizado de novo pode atuar agindo diretamente na desestabilização do mRNA para gp80 ou pode codificar para uma proteína envolvida no processo. Esta última possibilidade pôde ser verificada em experimentos onde utilizamos inibidores de síntese protéica. A fig. 12 mostra que o tratamento das células com estes inibidores previne o desaparecimento da mensagem. Nestes experimentos as células foram pré-tratadas com cicloeximida (fig. 12A) ou pactamicina (fig. 12B) por 30 minutos, antes da adição de $1 \mathrm{mM}$ de cAMP a metade da cultura. Ainda que a 


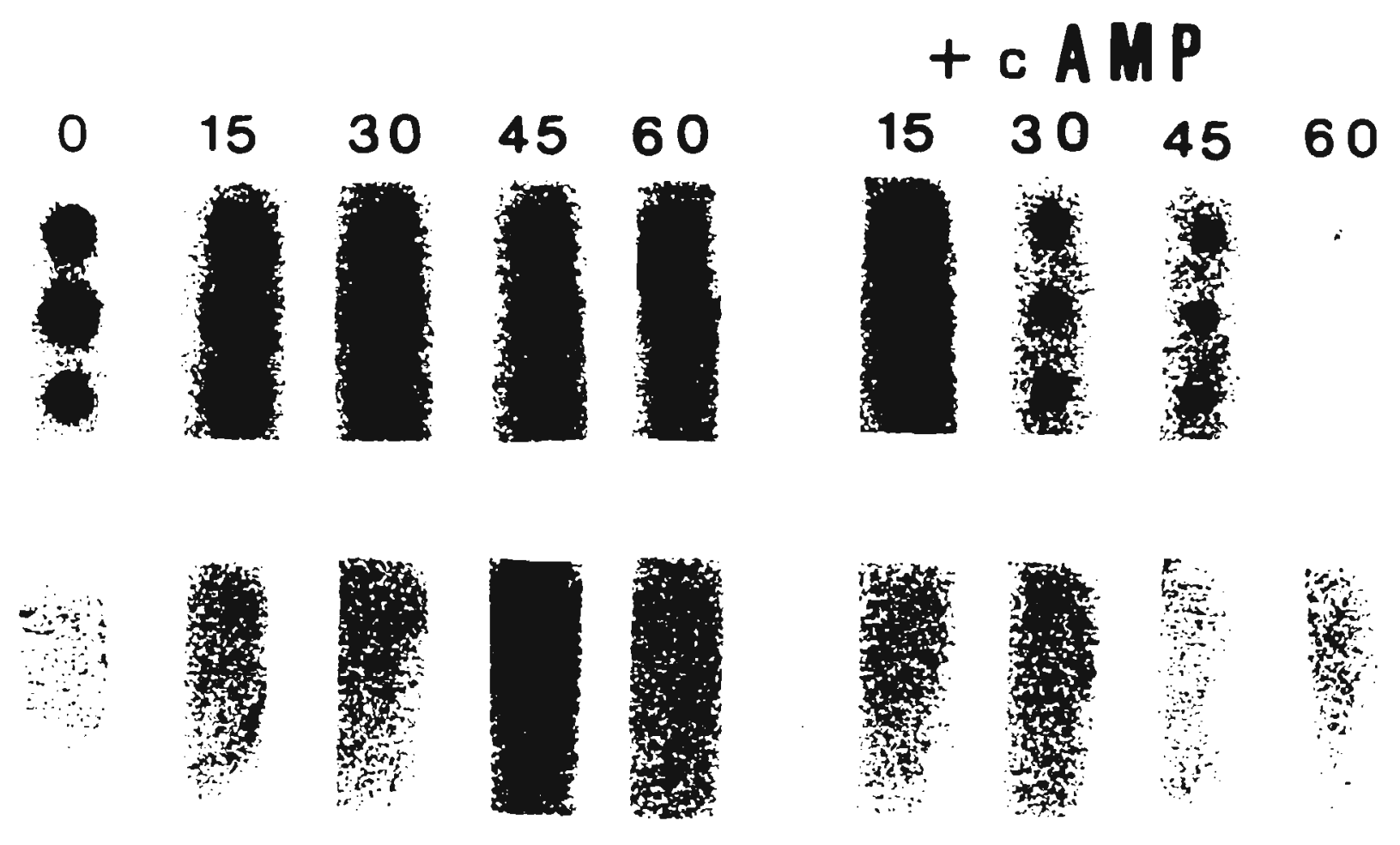

Fig. 10 - Auto-radiografia de "dot-blots" do plasmídeo Bluescribe contendo o cDNA para a gp80 (filtros de cima), ou somente o plasmideo Bluescribe (filtros de baixo). As células foram submetidas a carência em tampão MES $20 \mathrm{mM} \mathrm{pH} \mathrm{6,8} \mathrm{por} 5$ horas, incubadas com ${ }^{32} \mathrm{PO}_{4}$ por 1,5 horas, lavadas e incubadas em tampão $\mathrm{KH}_{2} \mathrm{PO}_{4} 20$ $\mathrm{mM} \mathrm{pH} \mathrm{6,4} \mathrm{por} 45$ minutos. cAMP para $1 \mathrm{mM}$ foi então adicionado à metade da população. Nos tempos indicados, após adição de cAMP, RNA total foi extraido e hibridizado contra os filtros. 
A

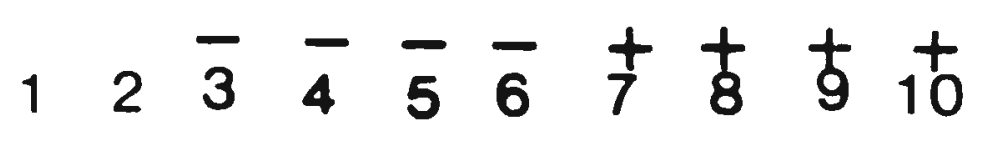
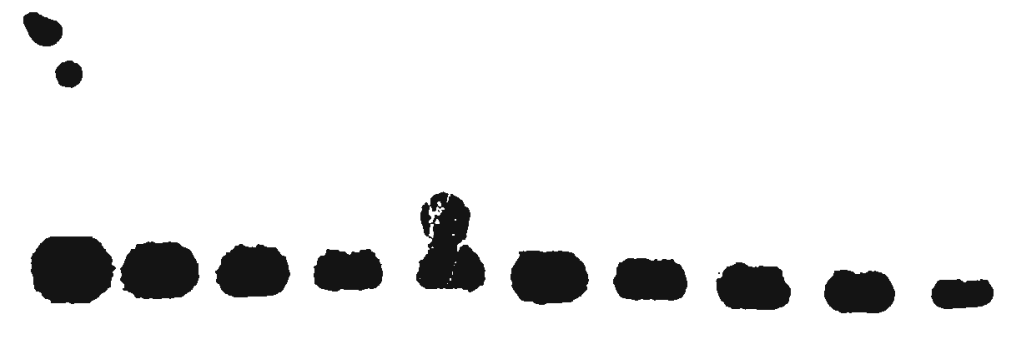

$\begin{array}{lllllllllll}B & & & - & - & - & - & + & + & + & + \\ & 1 & 2 & 3 & 4 & 5 & 6 & 7 & 8 & 9 & 10\end{array}$

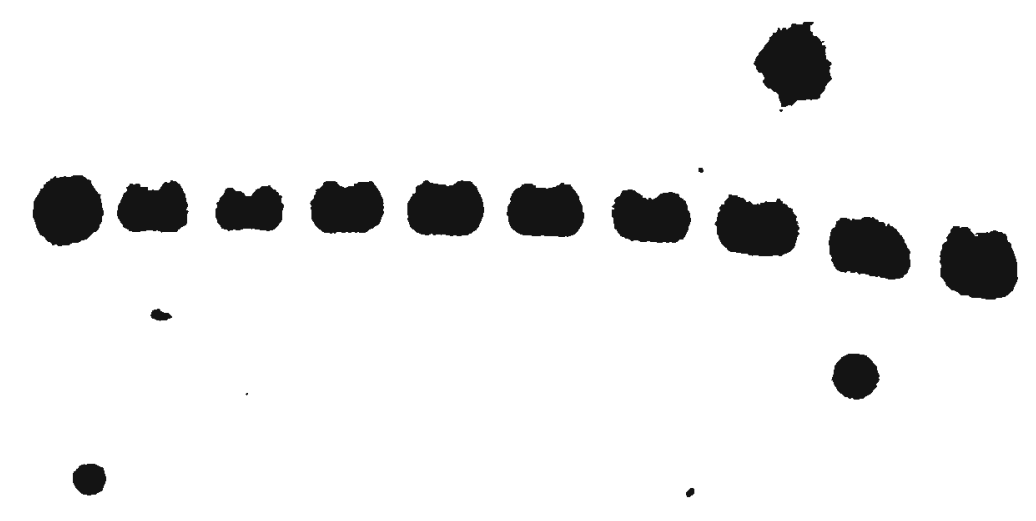

Fig. 11 - Auto-radiografia de "Northern blot" contendo RNA total de células AX2 submetidas a carência por 6 horas quando actinomicina D para $125 \mu \mathrm{g} / \mathrm{ml}$ e daunomicina para $250 \mu \mathrm{g} / \mathrm{ml}$ (A) ou nogalamicina para $300 \mu \mathrm{g} / \mathrm{ml}$ (B) foram adicionadas. Após 15 minutos $1 \mathrm{mM}$ de cAMP foi adicionado à metade das células (+). RNA foi extraido após 15, 30, 45 e 60 minutos de incubação com cAMP (7-10) ou sem cAMP (3-6). (1) RNA extraído antes da adição dos inibidores. (2) RNA extraído após 15 minutos de incubação com as drogas. O filtro foi hibridizado contra sonda correspondente ao CDNA da gp80. A equivalência da quantidade de RNA aplicada em cada poço foi verificada por coloração do gel com brometo de etídeo. 


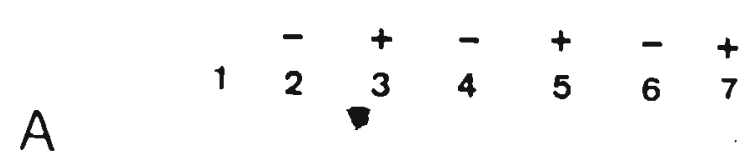

A



B





Fig. 12 - Auto-radiografia de "Northem blot" contendo RNA total de células AX2 submetidas a carência por 6 horas quando cicloeximida (A) ou pactamicina (B) para $300 \mu \mathrm{g} / \mathrm{ml}$ foram adicionadas. Após 30 minutos CAMP para $1 \mathrm{mM}$ foi adicionado à metade das células (+). RNA foi extraído após 0 (1), 20 minutos (3), 40 minutos (5) ou 60 minutos (7) de incubação com cAMP após tratamento com o inibidor, ou 20 minutos (2), 40 minutos (4) ou 60 minutos (6) adicionais de incubação somente com o inibidor. Os filtros foram hibridizados contra sonda correspondente ao cDNA da gp80. (C) Densitometria de um autoradiograma semelhante ao mostrado em B para quantificação dos niveis de mRNA para gp80 após tratamento com pactamicina (PM) (4) ou pactamicina + CAMP ( $\Delta$ ). Como controles as células foram incubadas na ausência de pactamicina e cAMP ( $\bullet$ ) ou somente com cAMP (o). A equivalência da quantidade de RNA aplicada em cada poço foi verificada por coloração do gel com brometo de etídeo. 
incubação apenas com os inibidores tenha causado uma diminuição nos níveis do mRNA para gp80, o tratamento adicional com cAMP não alterou estes níveis. Assim, aparentemente síntese protéica é necessária para que ocorra desestabilização do mRNA para gp80 quando o cAMP é adicionado em altas concentrações. A diminuição nos niveis do mRNA para gp80 quando as células foram incubadas apenas com os inibidores parece indicar que sintese protéica também é necessária na mariutenção dos niveis de mRNA para gp80.

3 - Estudo das vias de transdução de sinal ativadas durante a desestabilização do mRNA para gp80

\section{1 - Análise do papel de íons de cálcio}

Os resultados apresentados até aqui demonstraram que o mRNA para gp80 é desestabilizado quando células competentes para agregação são estimuladas com altas concentrações de cAMP (Juliani et al., 1990; este trabalho). Como este efeito parece ser mediado pelo receptor de CAMP, que sofre "down-regulation" nestas condições, nós realizamos experimentos destinados a investigar quais segundos mensageiros estariam participando da via de ativação da desestabilização em resposta ao cAMP. Mais precisamente, nós investigamos vias alternativas que não envolvessem cAMP intracelular já que demonstramos que mudanças nos niveis de cAMP intracelular não são necessárias para que a degradação ocorra.

Recentemente, foi demonstrado que um pulso de cAMP em concentrações micromolares $(1 \mu \mathrm{M})$, que mimetiza o sinal quimiotático, induz um influxo de $\mathrm{Ca}^{2+}$ em células competentes para agregação. $O$ influxo ocorre após 5 segundos da estimulação e termina após 25-30 segundos (Milne e Coukell, 1991). O cAMP nestas concentrações não induz "down-regulation" do receptor. Para verificarmos se influxo de $\mathrm{Ca}^{2+}$ ocorria em condições de "down-regulation" do receptor, medidas de tomada de $\mathrm{Ca}^{2+}$ por células competentes para agregação incubadas com $1 \mathrm{mM}$ de cAMP foram realizadas, utilizando-se ${ }^{45} \mathrm{Ca}^{2+}$. Como mostrado na fig. $13 \mathrm{~A}$, estimulação das células com $1 \mathrm{mM}$ de cAMP resulta num aumento da tomada de cálcio do meio. Em contraste com os resultados reportados utilizando-se concentrações micromolares de cAMP (Milne e Coukell, 1991), células tratadas com concentrações milimolares apresentam uma tomada prolongada deste cátion divalente. Após 30 minutos de incubação, células estimuladas com $1 \mathrm{mM}$ de CAMP acumulam aproximadamente $0,6 \mathrm{nmol} \mathrm{Ca}^{2+/ 10^{7}}$ células a mais que células não estimuladas. Neste período, a "down-regulation" do receptor em geral já se completou (Klein e Juliani, 1977) e a desestabilização do mRNA para gp80 já é detectada (Juliani et al., 1990; fig. 7 deste trabalho). Como 
A


Fig. 13 - (A) Células competentes para agregação foram tratadas ou não com $1 \mathrm{mM}$ de CAMP pelos tempos indicados e tomada de ${ }^{45} \mathrm{Ca}^{2}+$ foi determinada. Cada ponto é a média obtida de 4 experimentos. As barras representam o desvio padrão. Em um dos pontos a barra é menor que o símbolo. (B) Auto-radiografia de "Northem blot" contendo RNA total de células coletadas antes e após 60 minutos de incubação com CAMP $1 \mathrm{mM} \mathrm{(+)} \mathrm{durante} \mathrm{um} \mathrm{dos} \mathrm{experimentos} \mathrm{mostrados} \mathrm{em} \mathrm{(A).} \mathrm{O} \mathrm{filtro} \mathrm{foi} \mathrm{hibridizado}$ contra sonda correspondente ao cDNA da gp80. (C) Fotografia do gel representado em (B) antes da transferência para o filtro de nitrocelulose, mostrando, por coloração com brometo de etídeo, a equivalência da quantidade de RNA aplicada em cada poço do gel. 
controle, a desestabilização do mRNA para gp80 foi também verificada durante os ensaios de tomada de cálcio. A fig. 13B mostra os niveis de mRNA para gp80 de células tratadas ou não com $1 \mathrm{mM}$ de cAMP por 0 e 60 minutos, demonstrando que nas condições dos ensaios de tomada de $\mathrm{Ca}^{2+}$ o mRNA para gp80 foi desestabilizado.

Como a tomada de $\mathrm{Ca}^{2+}$ é estimulada em células que sofreram "downregulation" do receptor, nós decidimos investigar a participação deste cátion na desestabilização do mRNA para gp80. Inicialmente analisamos o efeito de diferentes concentrações do ionóforo A23187 nos níveis de mRNA para gp80 em células competentes para agregação. Como mostrado na fig. 14, $5 \mu \mathrm{M}$ de A23187 reduziu os níveis de mRNA para gp80 em aproximadamente $30 \%$ após 20 minutos de tratamento, e em $70 \%$ após 30 minutos. Tratamento com $1 \mu \mathrm{M}$ de A23187 foi menos efetivo, levando a uma diminuiçăo de aproximadamente $30 \%$ após 30 minutos de tratamento, demonstrando que o efeito é dependente da concentração de ionóforo presente (resultados não mostrados).

lonóforos podem causar fluxos de cálcio para dentro ou fora da célula, dependendo da concentração do ín no meio. É provável que o nível de cálcio contaminante nos tampões seja suficiente para permitir um influxo do cátion. No entanto, para eliminar a possibilidade de que uma depleção do cálcio celular, em oposição a um aumento da concentração citossólica, seja responsável pela degradação do mRNA, nós incubamos as células com $5 \mu \mathrm{M}$ de A23187 na presença de $2 \mathrm{mM}$ de $\mathrm{Ca}^{2+}$. Esta condição, como mostrado na fig. 15, foi muito mais eficiente na indução da desestabilização do mRNA para gp80 do que tratamento das células com apenas A23187. Em adição, a desestabilização do mRNA para gp80 foi acelerada quando $\mathrm{A} 23187$ e $\mathrm{Ca}^{2+}$ estavam presentes no meio de incubação. Em células tratadas apenas com A23187 a desestabilização do mRNA começa a ser detectada após um período de 5-7 minutos. Similarmente, células incubadas com altas concentrações de CAMP apresentam um período de 10-15 minutos até que a desestabilização seja detectada (Juliani et al., 1990; fig. 7 deste trabalho). Portanto, a presença de A23187 e $\mathrm{Ca}^{2+}$ parece eliminar ou encurtar este período, já que os níveis de mRNA para gp80 foram diminuídos em $40 \%$ após 5 minutos de tratamento. Estas observações sugerem que um aumento de $\mathrm{Ca}^{2+}$ intracelular media a desestabilização do mRNA para gp80 e que um certo período deve ser necessário para acumular a concentração apropriada de $\mathrm{Ca}^{2+}$ que ativa a via.

A extensão de diminuição dos niveis da mensagem em resposta aos diferentes tratamentos apresenta alguma variação em experimentos independentes. No entanto, em experimentos onde o efeito de cAMP e A23187 na presença de $\mathrm{Ca}^{2+}$ foram 
A


B



C



Fig. 14 - (A) Niveis de mRNA para gp80 observados após tratamento de células competentes para agregação com $5 \mu \mathrm{M}$ de A23187 pelos tempos indicados. Os valores foram obtidos por densitometria de um auto-radiograma (B) de "Northern blot" contendo RNA total hibridizado contra sonda correspondente ao cDNA da gp80. (C) Fotografia do gel antes da transferência para o filtro de nitrocelulose representado em (B), mostrando, por coloração com brometo de etideo, a equivalência da quantidade de RNA aplicada em cada poço do gel. 
A



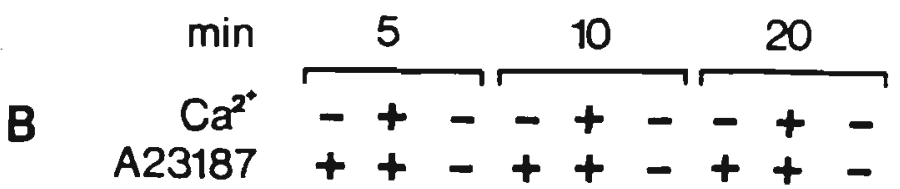

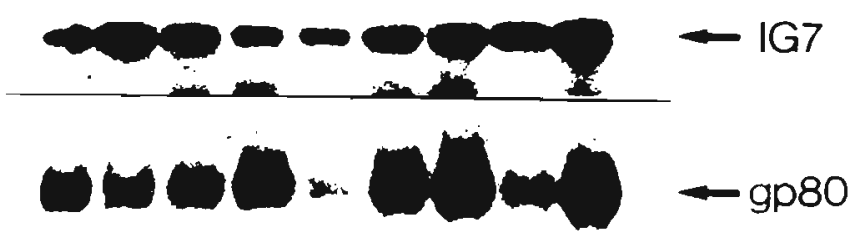

Fig. 15 - (A) Niveis de mRNA para gp80 observados após tratamento de células competentes para agregação com A23187 para $5 \mu \mathrm{M}$ e Ca${ }^{2+}$ para $2 \mathrm{mM}$ pelos tempos indicados. Os valores foram obtidos por densitometria de um auto-radiograma (B) de um "Northern blot" contendo RNA total hibridizado contra sonda correspondente ao cDNA da gp80 e ao gene $1 \mathrm{G} 7$. Os niveis de mRNA para o gene $1 \mathrm{G} 7$ foram utilizados para normalização da quantidade de RNA aplicada em cada poço do gel. 
comparados, notamos que tratamento com CAMP foi sempre mais efetivo. A fig. 16 mostra que células tratadas com $1 \mathrm{mM}$ de cAMP apresentam uma diminuição de $85 \%$ nos niveis do mRNA gp80 em 30 minutos, enquanto que células tratadas com A23187 na presença de $\mathrm{Ca}^{2+}$ mostraram $55 \%$ de perda da mensagem. Quando ambos os tratamentos foram combinados, uma perda total da mensagem foi observada em 30 minutos de tratamento. Este efeito provavelmente reflete o fato de que ambos iniciam um influxo do íon através da meınbrana plasmática aumentando os níveis de cálcio citoplasmático.

O conjunto destes dados sugere fortemente que um influxo de cálcio está envolvido na desestabilização do mRNA para gp80. Portanto, condições que bloqueassem este influxo deveriam impedir a desestabilização do mRNA que é induzida por altas concentrações de cAMP. Contudo, tentativas de inibir a desestabilização da mensagem utilizando $\mathrm{La}^{3+}$ e $\mathrm{Cd}^{2}+$ (dados não mostrados), que inibem, embora fracamente, o influxo de cálcio induzido por baixas concentrações de CAMP, ou rutênio vermelho (fig.17) um bloqueador de canal mais efetivo (Milne e Coukell, 1991) foram sem sucesso. Como mostrado na fig. 17 a desestabilização do mRNA para gp80 induzida por cAMP não é alterada quando células são pré-incubadas com rutênio vermelho, indicando que os possiveis canais que mediam este influxo de $\mathrm{Ca}^{2+}$, provavelmente não são sensiveis a estes compostos.

Para examinar o papel de $\mathrm{Ca}^{2+}$ armazenado em compartimentos citoplasmáticos na mediação da desestabilização da mensagem foram examinados os efeitos de $\mathrm{LiCl}$ e TMB-8 neste fenômeno. Estas drogas inibem liberação de cálcio de compartimentos citoplasmáticos em vários sistemas, inclusive Dictyostelium. Neste organismo, estes compostos foram utilizados para implicar ou excluir um papel de $\mathrm{Ca}^{2+}$ na mediação dos efeitos de uma variedade de estímulos (Europe-Finner e Newell, 1986; Van Lookeren Campagne et al., 1988; Europe-Finner e Newell, 1984; Blumberg et al., 1989). Se compartimentos intracelulares fossem a fonte de $\mathrm{Ca}^{2+}$ que media os efeitos de CAMP, estas drogas deveriam previnir a degradação do mRNA para gp80 induzida por CAMP. Como mostrado na fig. 18A, incubação das células com $5 \mathrm{mM}$ de $\mathrm{LiCl}$ não altera os niveis de mRNA para gp80 e também não é capaz de prevenir a degradação do mRNA da gp80 induzida por cAMP. Similarmente, células incubadas com 0,2 mM de TMB-8 também responderam ao tratamento com cAMP destabilizando o mRNA para gp80 (fig. 18B). Concentrações mais altas de TMB-8 não podem ser utilizadas porque, como reportado por Blumberg et al., 1989, tais condições levam a niveis significantes de morte celular. Em nossas condiçōes experimentais, tratamento com estas drogas nas concentrações indicadas não afetou a viabilidade 
A



B


Fig. 16 - (A) Niveis de mRNA para gp80 observados após tratamento de células competentes para agregação com A23187 para $5 \mu \mathrm{M}$, Ca ${ }^{2+}$ para $2 \mathrm{mM}$ e cAMP para $1 \mathrm{mM}$. Os valores foram obtidos por densitometria do auto-radiograma $(B)$ de um "Northern blot" contendo RNA total hibridizado contra sonda correspondente ao cDNA da gp80 e ao gene $1 \mathrm{G} 7$. Os niveis de mRNA para o gene $1 \mathrm{G} 7$ foram utilizados para normalização da quantidade de RNA aplicada em cada poço do gel. 
A

CAMP +-+-
RV ++--



Fig. 17 - Auto-radiografia de "Northern blot" contendo RNA total de células AX2 submetidas a carência por 6 horas quando rutênio vermelho para $15 \mu \mathrm{M}$ foi adicionado. Após 20 minutos $1 \mathrm{mM}$ de cAMP foi adicionado à metade das células. RNA foi extraido após 60 minutos de incubação com cAMP. Os filtros foram hibridizados contra sonda correspondente ao cDNA da gp80 e do gene 1 G7. 

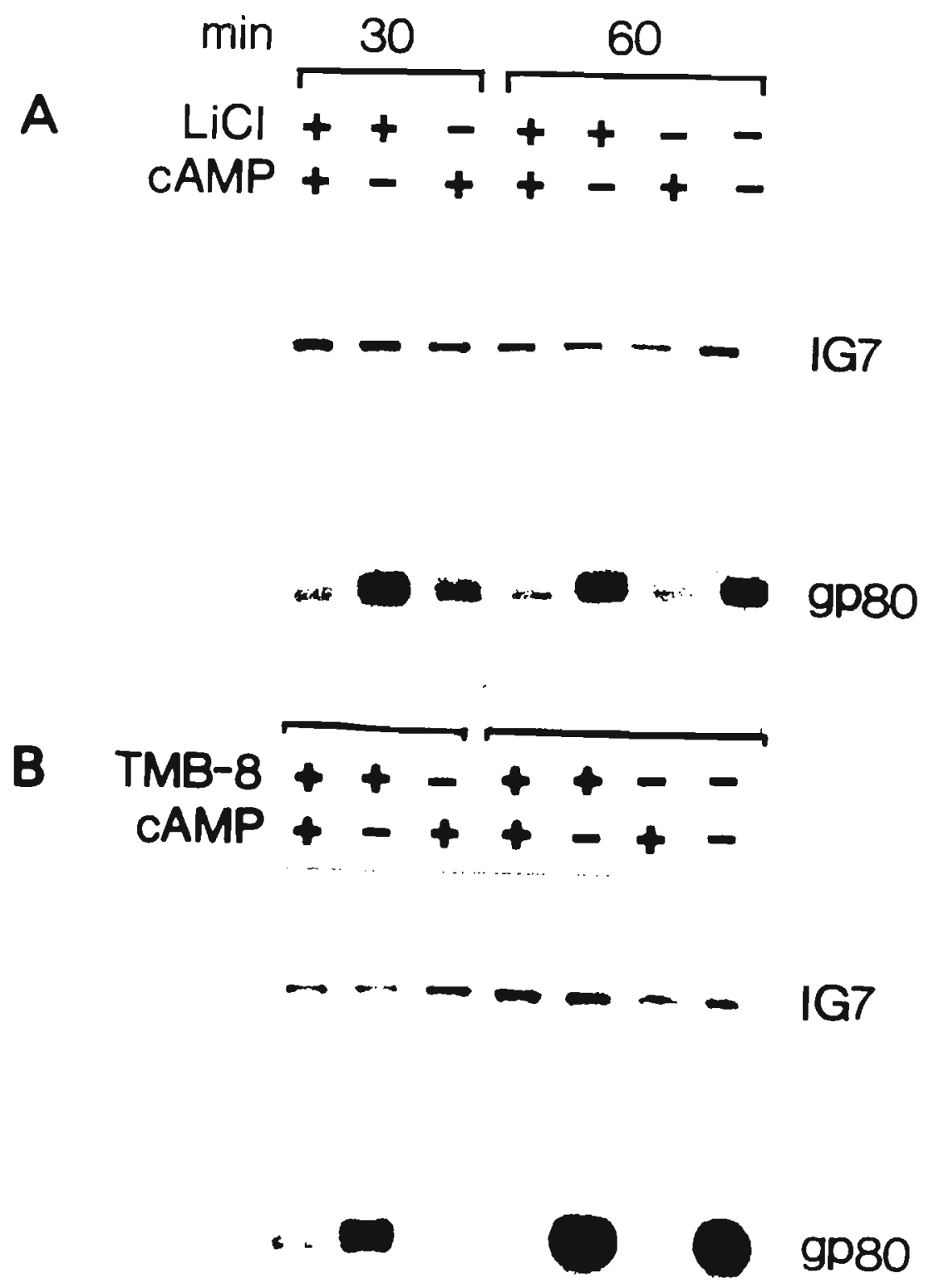

Fig. 18 - Auto-radiografia de "Northern blot" contendo RNA total de células AX2 submetidas a carência por 6 horas quando $\mathrm{LiCl}$ (A) para $5 \mathrm{mM}$ ou TMB-8 (B) para 0,2 $\mathrm{mM}$ foram adicionados. Após 20 minutos $1 \mathrm{mM}$ de CAMP foi adicionado à metade das células. RNA foi extraido após 30 e 60 minutos de incubação com cAMP. Os filtros foram hibridizados contra sonda correspondente ao cDNA da gp80 e do gene 1 G7. 
das células. A soma destes dados sugere que liberação de $\mathrm{Ca}^{2+}$ de compartimentos intracelulares não é necessária para que desestabilização do mRNA para gp80 ocorra. Uma outra evidência que confirma esta conclusão é a observação de que tratamento de células competentes para agregação com altas concentrações do antagonista quimiotático parcial 8-CPT-cAMP também é capaz de induzir desestabilização do mRNA para gp80 como mostrado na fig. 19. Recentemente foi reportado que as células respondem a este antagonista parcial aumentando os niveis dos mensageiros secundários CAMP e CGMi de uma maneira similar a células estimuladas com CAMP. No entanto, este composto é incapaz de provocar um aumento de $\mathrm{IP}_{3}$, e na verdade causa uma diminuição deste mensageiro secundário (Peters et al., 1991a). Como um aumento de $\mathrm{IP}_{3}$ media a liberação de $\mathrm{Ca}^{2+}$ dos compartimentos intracelulares, células estimuladas com 8-CPT-cAMP não seriam capazes de fazê-lo. Uma vez que 8-CPTCAMP induz diminuição dos níveis de mRNA para gp80, podemos inferir que $\mathrm{Ca}^{2+}$ liberado dos compartimentos citoplasmáticos não deve participar do processo.

Ocupação do receptor por cAMP em condições que levam a sua "downregulation" pode também induzir processos que não são diretamente relacionados a este fenômeno. Por exemplo, desde que o receptor está ocupado pelo ligante durante este processo e portanto possivelmente ativado, tal ocupação poderia induzir uma variedade de eventos independentes da "down-regulation". Juliani e Klein (1977) demonstraram que a "down-regulation" do receptor pode ser induzida tratando-se as células com ConA e que tal tratamento não envolve ativação do receptor pelo ligante. Portanto, nós poderíamos investigar se "down-regulation" do receptor seria suficiente para induzir tomada de cálcio e desestabilização do mRNA para gp80. Os resultados de medida de tomada de cálcio apresentados na fig. 20A confirmam esta premissa, e notamos que ConA induziu tomada de cálcio em niveis maiores do que os induzidos por cAMP. Como esperado, tratamento com ConA também causa uma maior desestabilização do mRNA para gp80 (fig. 20B).

3.2 - Envolvimento da proteína quinase $C$ na regulação da desestabilização do mRNA para gp80

O conjunto dos nossos dados sugerem que a "down-regulation" do receptor está associada a um influxo de $\mathrm{Ca}^{2+}$ e que este poderia funcionar como um segundo mensageiro na indução da degradação do mRNA para gp80. Com o objetivo de iniciarmos uma investigação sobre o mecanismo pelo qual o fluxo de $\mathrm{Ca}^{2}+$ pela membrana ativa a desestabilização do mRNA fizemos alguns experimentos utilizando staurosporin para excluir ou implicar a proteina quinase $\mathrm{C}$ no processo. Staurosporin é um potente inibidor desta quinase (Tamaoki et al., 1986) e foi reportada como um 

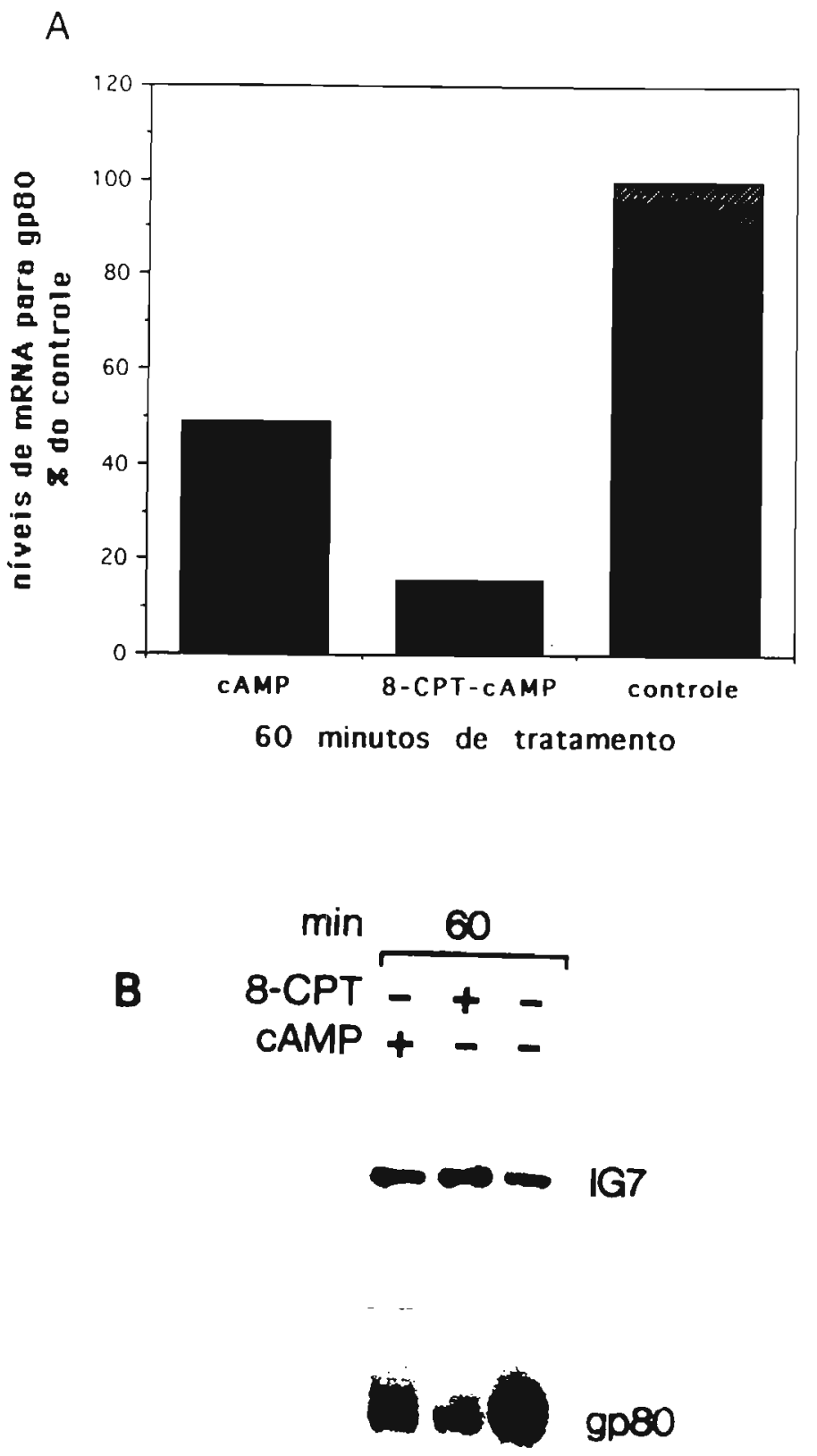

Fig. 19 - (A) Niveis de mRNA para gp80 observados após tratamento de células competentes para agregação com 8-CPT-cAMP ou cAMP para $1 \mathrm{mM}$ por 60 minutos. Os valores foram obtidos por densitometria de um auto-radiograma $(B)$ de "Northern blot" contendo RNA total hibridizado contra sonda correspondente ao cDNA da gp80 e ao gene $1 \mathrm{G} 7$. Os niveis de mRNA para o gene $1 \mathrm{G} 7$ foram utilizados para normalização da quantidade de RNA aplicada em cada poço do gel. 
A

\begin{tabular}{|c|c|c|c|}
\hline & nmol de & $\mathrm{Ca}^{2}+/ 10^{7}$ & células \\
\hline Tempo (min) & Controle & cAMP & CunA \\
\hline 10 & 1.02 & 2.04 & 2.24 \\
\hline 20 & 1.39 & 1.86 & 2.80 \\
\hline 30 & 1.14 & 1.93 & -54 \\
\hline
\end{tabular}

B

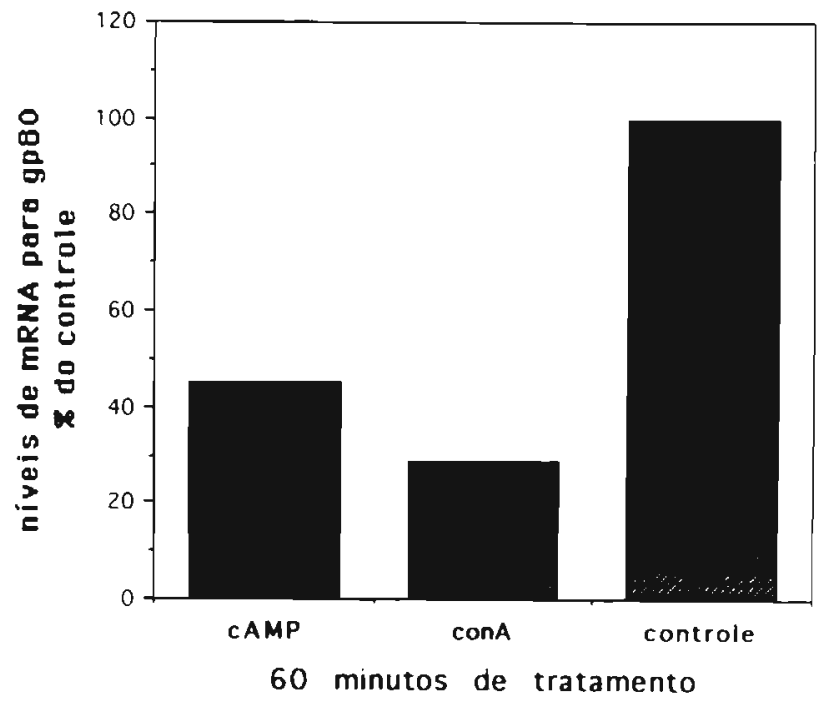

Fig. 20 - (A) Tomada de ${ }^{45} \mathrm{Ca}^{2+}$ por células competentes para agregação tratadas ou não com $1 \mathrm{mM}$ de cAMP ou $100 \mu \mathrm{g} / \mathrm{ml}$ de ConA pelos tempos indicados. (B) Níveis de mRNA para gp80 observados após tratamento de células competentes com $1 \mathrm{mM}$ de cAMP ou $100 \mu \mathrm{g} / \mathrm{ml}$ de ConA por 60 minutos. Os valores foram obtidos por densitometria de um auto-radiograma de um "Northem blot" contendo RNA total hibridizado contra sonda correspondente ao cDNA da gp80 e ao gene 1G7. Os niveis de mRNA para o gene $1 G 7$ foram utilizados para normalização da quantidade de RNA aplicada em cada poço do gel. 
inibidor da atividade de proteina quinase C em Dictyostelium (Lúderus et al., 1989). Como mostrado na fig. 21, o tratamento de células competentes para agregação com staurosporin causa uma diminuição dos niveis do mRNA para gp80 após 30 minutos de incubação. As razões para este efeito são ainda desconhecidas. No entanto, apesar de staurosporin não afetar significantemente os niveis do transcrito para gp80 durante os primeiros 30 minutos de incubação, neste tempo foi capaz de inibir parcialmente a ação do cAMP. Na presença de staurosporin, tratamento com $1 \mathrm{mM}$ de cAMP produziu apenas $25 \%$ de diminuição dos niveis da mensagem, enquanto que na ausência da droga, cAMP induziu uma perda de $45 \%$ do transcrito no mesmo periodo. Nenhum efeito de staurosporin foi observado nos niveis de mRNA para o transcrito 1G7. A droga tarnbém não afetou a viabilidade das células nas condições em que os experimentos foram realizados.

Ainda que preliminares estes dados sugerem o envolvimento da proteina quinase $\mathrm{C}$ na desestabilização do mRNA da gp80 induzido por cAMP. Para confirmar o envolvimento desta proteina analisamos o efeito do éster de forbol PMA, um ativador de proteína quinase $C$, nos níveis de mRNA para gp80. Contudo, como mostrado na fig. 22, PMA não afetou a desestabilização deste transcrito induzida por $1 \mathrm{mM}$ de CAMP, nem alterou os níveis de mRNA para gp80 de células controle. A ausência de qualquer efeito de PMA provavelmente deve-se ao fato de que este composto não parece alterar a atividade de proteína quinase $C$ quando utilizado in vivo em Dictyostelium (Van Haastert et al., 1985; Claudette Klein, comunicação pessoal).

\section{4 - Estudo da desestabilização do mRNA para gp80 em outras fases do desenvolvimento \\ Como continuidade dos estudos sobre os mecanismos envolvidos na} desestabilização do mRNA para gp80 decidimos investigar se este fenômeno era restrito a células competentes para agregação ou seja, se era regulado pelo desenvolvimento. Para tal seria necessário a obtenção de linhagens de Dictyostelium que expressassem o mRNA da gp80 constitutivamente para procedermos a análise da sua estabilidade ao longo do desenvolvimento, em resposta aos tratamentos que instabilizam este mRNA como por exemplo, incubação com altas concentrações de cAMP ou ionóforo de cálcio.

\section{1 - Construção da quimera gp80-sUC}

Para a obtenção de linhagens que expressassem o mRNA para gp80 constitutivamente células de Dictyostelium foram transformadas estavelmente com um vetor de expressão contendo o cDNA da gp80 sob controle de um promotor 
A

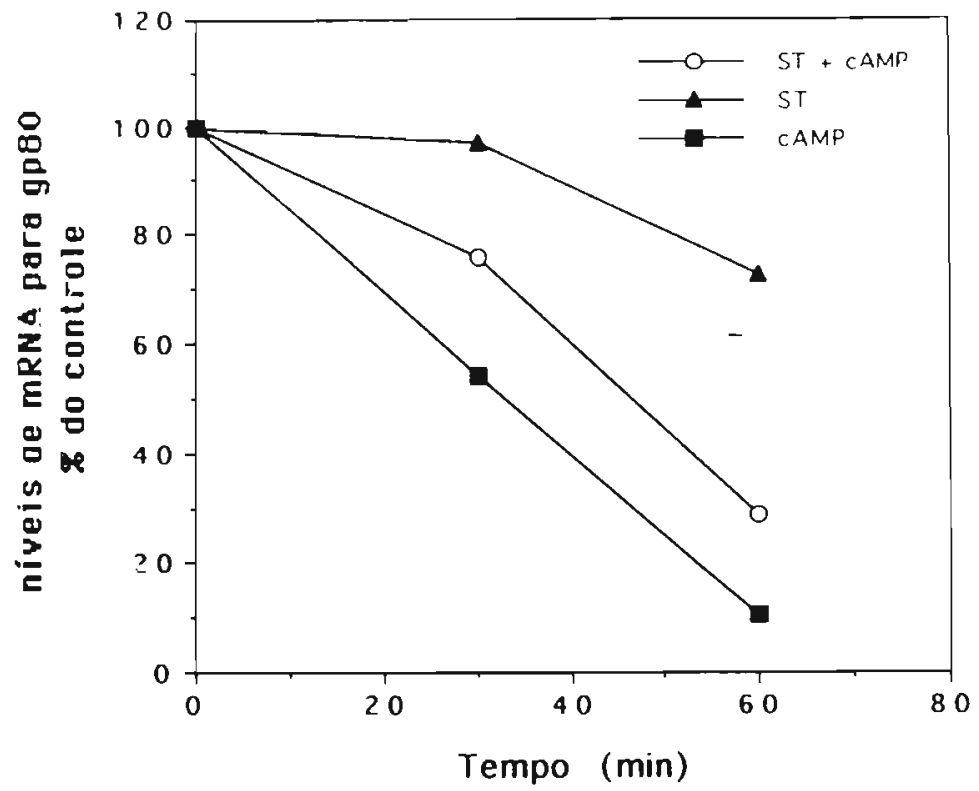

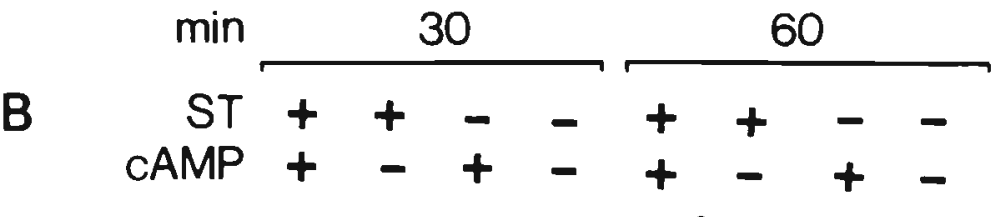

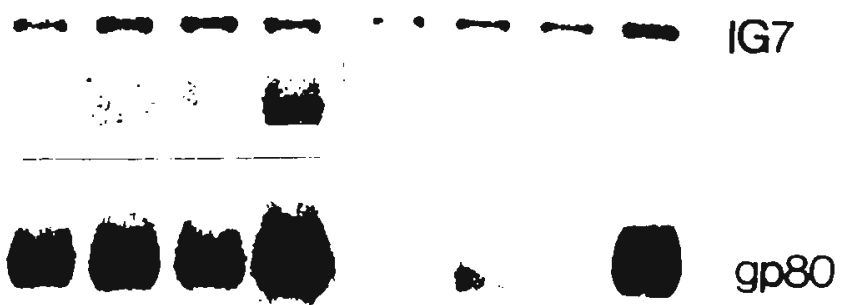

Fig. 21 - (A) Níveis de mRNA para gp80 observados após tratamento de células competentes para agregação com $1 \mathrm{mM}$ de cAMP ou $5 \mu \mathrm{M}$ de staurosporin (ST) pelos tempos indicados. Os valores foram obtidos por densitometria de um auto-radiograma (B) de um "Northern blot" contendo RNA total hibridizado contra sonda correspondente ao cDNA da gp80 e ao gene 1G7. Os niveis de mRNA para o gene $1 G 7$ foram utilizados para normalização da quantidade de RNA aplicada em cada poço do gel. 


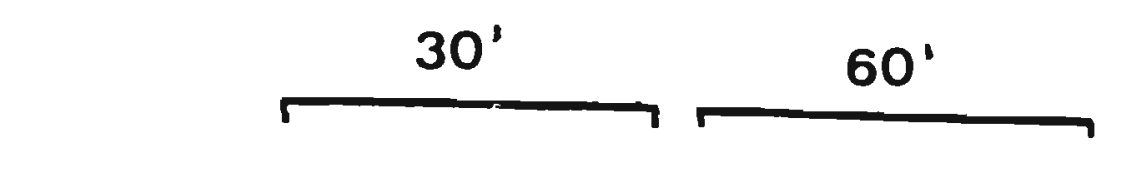
CAMP +-+-+-+
PMA ++--++-

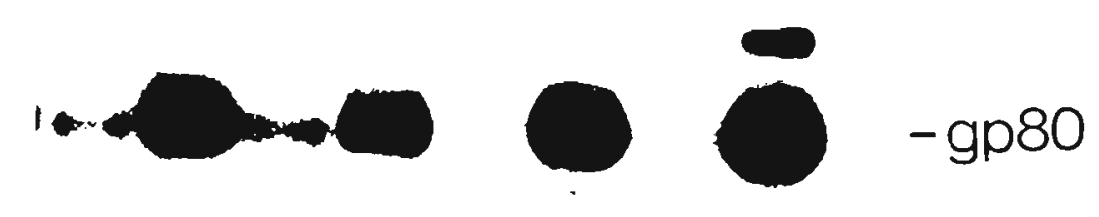

Fig. 22 - Auto-radiografia de "Northern blot" contendo RNA total de células AX2 submetidas a carência por 6 horas quando PMA para $8 \mu \mathrm{M}$ foi adicionado. Após 20 minutos $1 \mathrm{mM}$ de cAMP foi adicionado à metade da população. RNA foi extraído após 30 ou 60 minutos de incubação com cAMP. Os filtros foram hibridizados contra sonda correspondente ao cDNA da gp80. 
constitutivo. Como vetor de expressão utilizamos o plasmídeo pCytXNeoR (fig.23) (Pivi et al., 1993). Este vetor integra-se em várias cópias em série no genoma de Dictyostelium e a expressão do cDNA de interesse é dirigida pelo pronotor do gene da citocromo oxidase5 de Dictyostelium discoideum (Rizzuto et al., 1993). Além disso, como o laboratório não dispunha de mutantes de Dictyostelium que não expressam o gene da gp80 e como a frequência de recombinação romóloga em Dictyostelium é relativamente baixa (Nellen et al., 1987), o que dificulta a substituição do gene natural pelo cDNA no genoma da célula, o cDNA da gp80, a ser expresso constitutivamente, deveria conter alguma identificação para que fosse possivel distinguir o mRNA correspondente (expresso sob o controle do promotor da citocromo oxidase, e portanto constitutivamente) do mRNA "endógeno" (expresso sob o controle do promotor natural da gp80).

Assim, para identificar o cDNA da gp80, inserimos um fragmento de 63 aminoácidos (189 bp) do gene SUC2 de levedura (Johnson et al.,1987; Kleonsky et al, 1988) em fase entre as bases 1188 e 1189 do cDNA da gp80 já clonado no sítio EcoRl


plasmideo pSEY304 que contém o gene SUC (fig. 24C). Inicialmente foi importante nos certificarmos que ele não reconheceria nenhuma sequência de mRNA de Dictyostelium discoideum. Como mostrado na fig. 24B não detectamos nenhuma hibridização do fragmento de 189 pb contra RNA de células vegetativas (raia 1), células carenciadas (raia 2) e células pulsadas com cAMP (raia 3). O mesmo "Northem" foi hibridizado contra o cDNA da gp80 (fig. 24A) como controle. Uma vez comprovado que não havia hibridização do fragmento $S U C$ com o mRNA das células de Dictyostelium, este fragmento foi então ligado em fase ao pCytXNeoR-gp80 previamente digerido com Hincll e desfosforilado. Após transformação de bactérias HB101, os clones que continham o cDNA quimera (cDNA gp80-SUC) foram identificados por análise do DNA digerido com EcoRI. Foram selecionados clones cujo inserto eram maiores que o cDNA da gp80 (fig. 25A) e a orientação em que o fragmento de $189 \mathrm{pb}$ havia se ligado ao cDNA da gp80 foi determinada. $A$ inserção do fragmento SUC no cDNA na orientação 5'-3' criaria um sítio para a enzima Hpal, o que não ocorreria se a inserção ocorresse na orientação inversa. A figura (25B, raia 2) mostra a digestão com $\mathrm{Hpal}$ do DNA de um dos clones em que o fragmento SUC foi inserido na orientação 5'-3'. Este clone, chamado pCytXNeoR-gp80-SUC, foi então utilizado na transformação de células de Dictyostelium.

\section{2 - Obtenção de linhagens de Dictyostelium que expressam a quimera gp80-SUC constitutivamente}




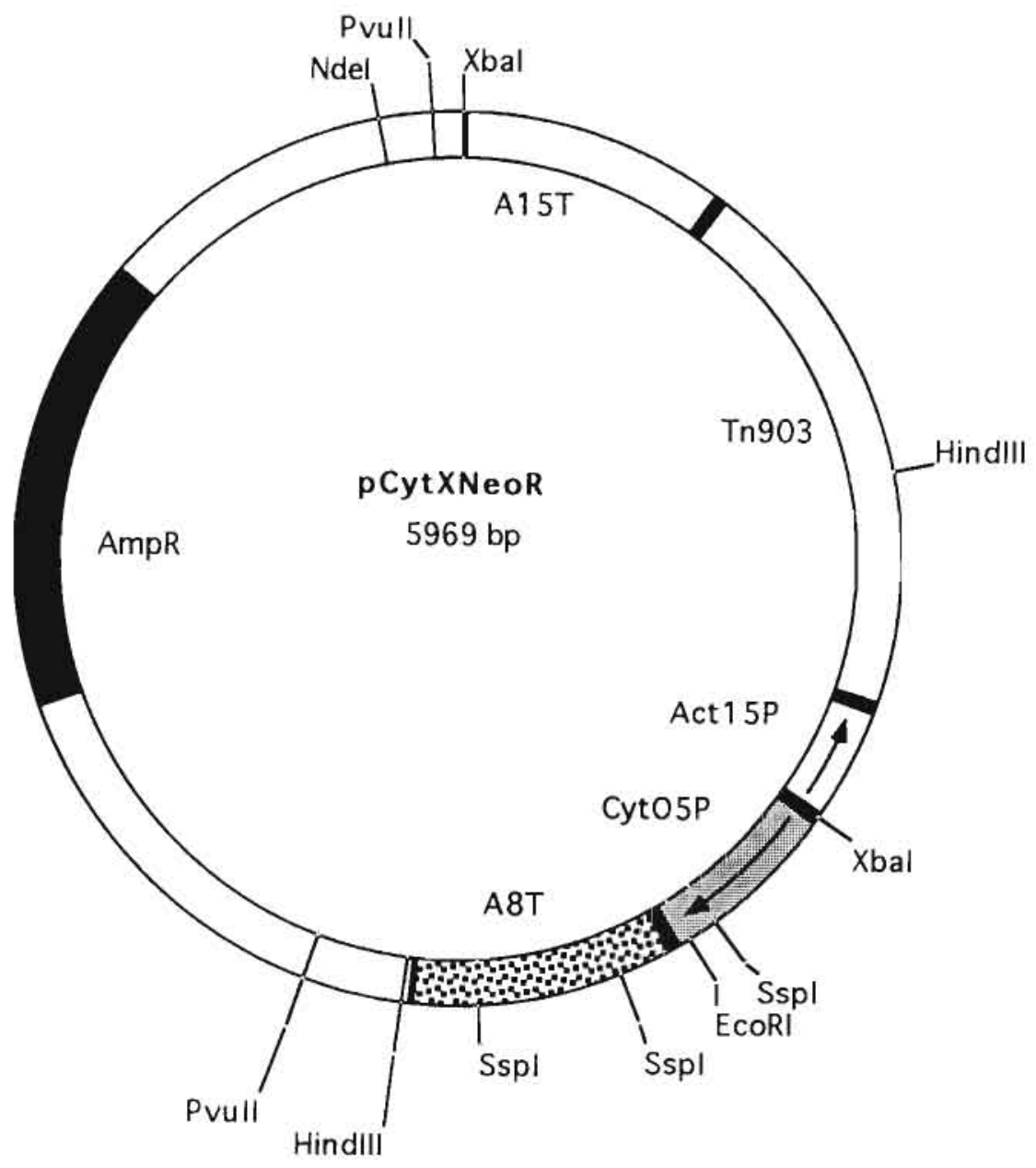

Fig. 23 - Mapa do vetor de expressão pCytXNeoR (Pivi et al., 1993) que permite expressão de cDNA sob o controle do promotor da citocromo oxidase (CytO5P) e do terminador da actina (A8T). A resistência à geneticina é conferida pelo cassete Tn903. O sitio para clonagem do cDNA é o sítio de EcoRI. 
A

V C P

gp80

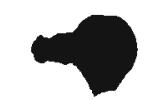

$V$ C P

B

suc

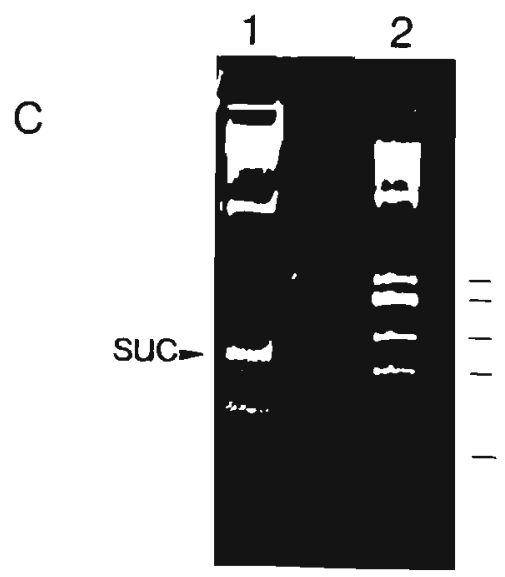

Fig. 24 - Auto-radiografia de "Northern blots" contendo RNA total do mutante Agip45 de células vegetativas (V), células carenciadas por 8 horas $(C)$ e células submetidas a carência na presença de pulsos de CAMP por 8 horas $(P)$, hibridizados contra sonda do CDNAs para gp80 (A) ou do fragmento $S U C$ de 189 pb (B). (C) Eletroforese em gel de poliacrilamida do DNA do clone pSEY304 digerido com a enzima de restriçāo Hincll (1). O fragmento SUC de 189 pb está indicado pela flecha. (2) DNA do fago $\phi \times 174$ digerido com Haelll utilizado como marcador de peso molecular. As bandas de cima para baixo correspondem aos pesos moleculares de 281, 234, 194, 118 e 72 pb. 
Células vegetativas de Dictyostelium foram transformadas com o plasmideo pCytXNeoR-gp80-SUC e após seleção com o antibiótico geneticina, a população de clones resistentes (chamados T80-SUC) foi analisada quanto a expressão do mRNA gp80-SUC. O RNA total destas células na fase de crescimento vegetativo foi extraído e o nivel do mRNA para gp80-SUC foi analisado pela hibridização de "Northem blots" contra a sonda do cDNA para gp80 (fig. 26A, raia 3), comparando-o com os niveis de mRNA da gp80 de células vegetativas da linhagem selvagem (raia 1) e células competentes para agregação da linhagem selvagem (raia 2). Como pode ser observado, o mRNA expresso na lirhagem T80-SUC possui peso molecular maior que - mRNA da linhagem selvagem, devido à inserção do fragmento SUC. Um filtro idêntico foi hibridizado com o fragmento $S U C$ de $189 \mathrm{pb}$ (fig. 26B) demonstrando que apenas a linhagem T80-SUC (raia 3) expressa o mRNA gp80-SUC.

As células do transformante T80-SUC formam pequenos agregados durante 0 crescimento ao contrário do observado em células transformadas com o cDNA da gp80 que formam grandes agregados (da Silva e Klein, 1990; Pivi et al., 1993). Para verificar se os transformantes T80-SUC produziam de fato uma proteina quimera gp80SUC foi feita a imunodeteç̧ão da proteína em "Western blots". O extrato total das células foi submetido a eletroforese em gel de poliacrilamida $10 \%$ (SDS-PAGE), seguida de transferência para filtro de nitrocelulose. O filtro foi incubado com anticorpo policlonal contra gp80 (Sadeghi et al., 1987). Na fig. 27 podemos observar que os transformantes T80-SUC (raia 4) expressam uma proteina de peso molecular maior que a gp80 expressa pela linhagem selvagem durante a fase de agregação (raia 2), o que era esperado devido à inserção do fragmento SUC. Células vegetativas da linhagem selvagem ou de uma linhagem transformada somente com o vetor pCytXNeoR sem inserto não expressam a gp80 (raias 1 e 3). É possivel que a inserção do fragmento SUC diminua as propriedades adesivas da gp80, mas estudos adicionais são necessários para esclarecermos este ponto.

\section{3 - Estudo da estabilidade do mRNA gp80-SUC}

Os niveis do mRNA gp80-SUC nas linhagens T80-SUC foram analisacios em "Northern blots" hibridizados contra o fragmento $S U C$, para compararmos o efeito de CAMP ou ionóforo de cálcio na estabilidade do mRNA tanto durante o crescimento vegetativo como em células durante a agregação. Podemos observar na fig. 28A que 0 tratamento com $1 \mathrm{mM}$ de cAMP não desestabiliza o mRNA gp80-SUC durante o crescimento vegetativo (compare raias 1 e $2 ; 3$ e 4), mas induz a desestabilização do mRNA em células submetidas a carência por $4 \mathrm{~h}$ (compare raias 5 e 6; 7 e 8). A ausência do efeito de cAMP na estabilidade do mRNA gp80-SUC durante 0 

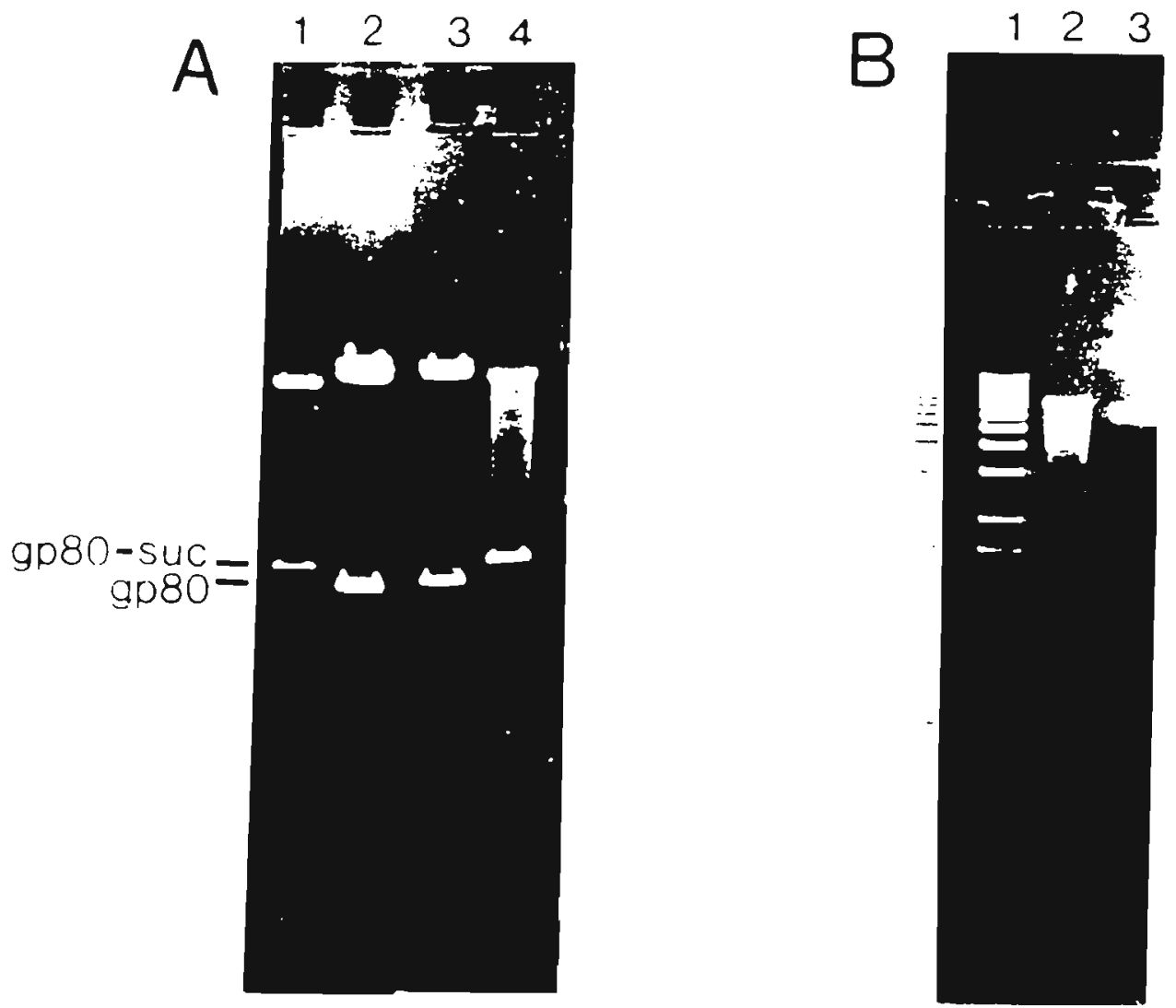

Fig. 25 - (A) Eletroforese em gel de agarose do DNA de clones pCytXNeoR-gp80 ligados ao fragmento $S U C$ e digeridos com ECoRI. (1 e 4) Clones que apresentam o inserto SUC. (2 e 3) Clones que não apresentam o inserto SUC. (B) Eletroforese em gel de agarose do DNA dos clones pCytXNeoR-gp80-SUC digeridos com Hpal. (2) Clone na orientação correta linearizado por Hpal. (3) Clone na orientação inversa que não é digerido por Hpal. (1) Marcador de peso molecular. Os pesos moleculares indicados na figura são de cima para baixo: $9,8,7,6,5,4,3,2,1,6,1 \in 0,5 \mathrm{~kb}$. 
A

B $\begin{array}{lll}1 & 2 & 3\end{array}$

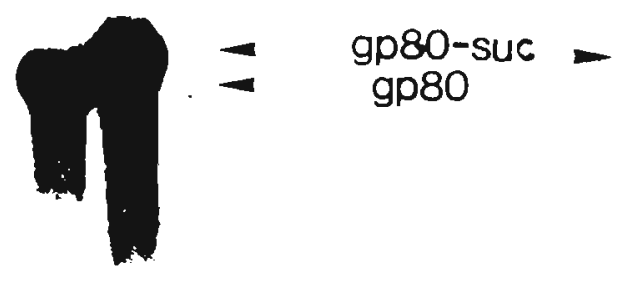

Fig. 26 - Auto-radiografia de "Northern blots" contendo RNA total de células vegetativas da linhagem selvagem AX2 (1), células da linhagem selvagem competentes para agregação (2) e células vegetativas da linhagem T80-SUC (3) hibridizados contra sonda do cDNA para gp80 (A) ou do fragmento $S U C$ de 189 pb (B). A posição do mRNA para gp80 e gp80-SUC está indicada. 


\section{$\begin{array}{llll}1 & 2 & 3 & 4\end{array}$}

191 -

\section{7}

91 .

72_

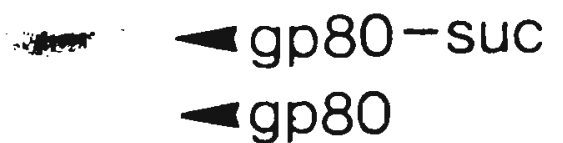

Fig. 27 - Auto-radiografia de um "Westem blot" contendo extrato total de células vegetativas da linhagem selvagem AX2 (1), células da linhagem selvagem competentes para agregação (2), células vegetativas transformadas somente com o vetor pCytXNeoR (3) ou células vegetativas da linhagem T80-SUC (4). O filtro foi incubado com anticorpo anti-gp80 e 125/-Proteina A. Os marcadores de peso molecular estão indicados em kDa a esquerda da figura. 
crescimento é coerente com o fato de que na fase vegetativa as células não expressam o receptor de cAMP, que também é regulado pelo desenvolvimento, e media a desestabilização. Por outro lado, tratamento do transformante T80-SUC com 5 $\mu \mathrm{M}$ de $\mathrm{A} 23187$ e $2 \mathrm{mM}$ de $\mathrm{Ca}^{2+}$ é capaz de induzir a desestabilização da mensagem gp80-SUC (fig. 29A) tanto em células submetidas a carência por 4 horas (compare raias 5 e 6; 7 e 8), como em células vegetativas (compare raias 1 e 2; 3 e 4). Como controle em ambos os experimentos "Northem blots" idênticos foram hibridizados com sondas do cDNA da gp80 (fig. 28B e 295). Nas figuras 28B e 29B podemos também observar o aparecimento da mensagem para gp80 endógena a partir de 4 horas de carência.

Estes resultados indicam que o fenômeno de desestabilização pode ser observado em células da fase de crescimento e que a ação vo A23187 contoma a necessidade de ativação do receptor de CAMP exercendo assim um "by pass" na via de desestabilização em questão. 


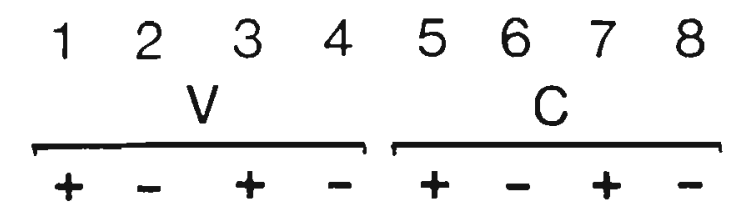

A

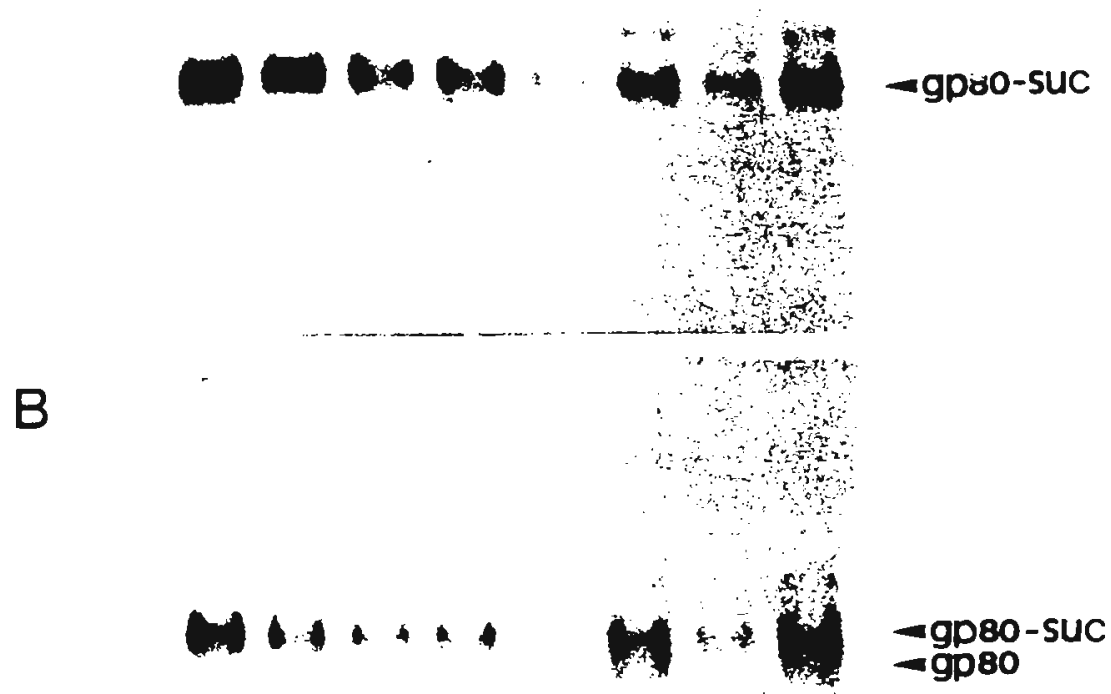

Fig. 28 - Auto-radiografia de "Northern blots" contendo RNA total de células vegetativas (V) ou submetidas a carência por 4 horas (C) da linhagem T80-SUC. O sinal (+) indica que cAMP para $1 \mathrm{mM}$ foi adicionado por 30 (1 e 5) ou 60 (3 e 7) minutos. Os filtros foram hibridizados contra sonda correspondente ao fragmento SUC (A) ou cDNA da gp80 (B). A equivalência da quantidade de RNA aplicada em cada poço foi verificada por coloração do gel com brometo de etídeo. 


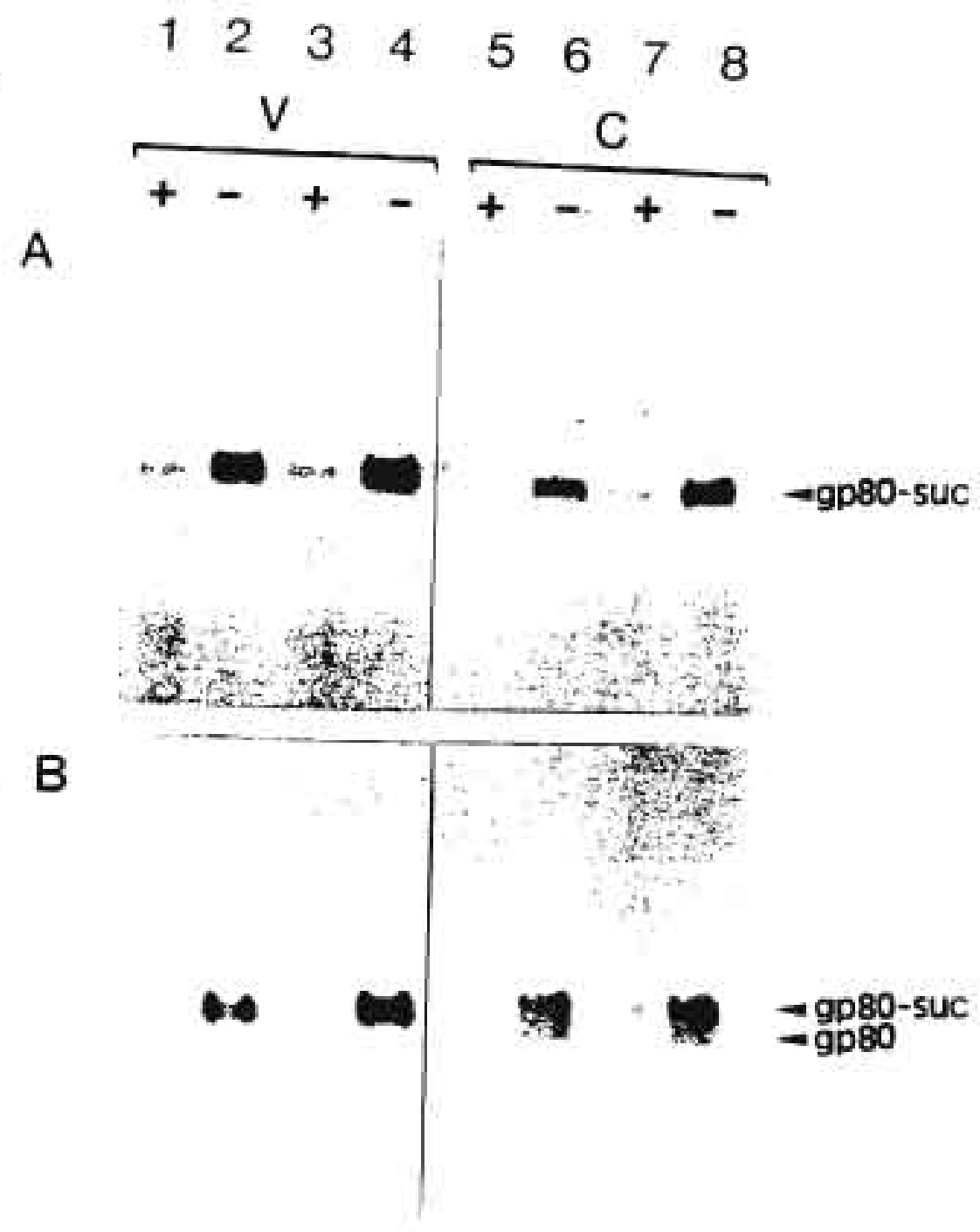

Fig. 29 - Auto-radiografia de "Northem blots" contendo RNA total de células vegetativas (V) ou submetidas a carência por 4 horas (C) da tinhagem T80-SUC. O sinal (+) indica que A23187 para $5 \mu \mathrm{M}$ e $\mathrm{Ca}^{2+}$ para $2 \mathrm{mM}$ foram adicionados por $15(1$ e 5 ) ou $30(3 \mathrm{e}$ 7) minutos. Os filtros foram hibridizados contra sonda correspondente ao fragmento SUC (A) ou cDNA da gp80 (B). A equivalência da quantidade de RNA aplicada em cada poço foi verificada por coloração do gel com brometo de etideo. 


\section{IV - DISCUSSÃO}

O cAMP em Dictyostelium discoideum exerce um papel fundamental no controle do desenvolvimento, agindo tanto como um mensageiro primário quanto secundário, funcionando como um sinal quimiotático e regulando a expressão de vários genes. Com o objetivo de estudarmos os mecanismos de controle da expressão gênica por cAMP neste organismo, foi isolado um clone de cDNA correspondente a um mRNA cuja expressāo era regulada por CAMP, e caracterizádo como sendo correspondente à molécula de adesão celular gp80.

A gp80 é expressa em células competentes para agregação e media a formação de contatos resistentes a EDTA (Muller e Gerisch, 1978). A transcrição do gene da gp80 é estimulada pelo tratamento das células com pulsos de concentrações micromolares de cAMP (Noegel et al., 1986; Siu et al., 1988; Juliani et al., 1990; Ma e Siu, 1990; este trabalho). Este aumento na transcrição parece refletir a ativação de um receptor de CAMP farmacologicamente distinto do receptor quimiotático (Ma e Siu, 1990) e a regulação da expressão do gene parece ser mediada por um único elemento responsivo a CAMP no seu promotor (Desbarats et al., 1992). Contudo, aumento dos níveis intracelulares de cAMP parece não estar envolvido na ativação da transcrição deste gene, como demonstram os experimentos onde utilizamos cafeina para bloquear a adenilato ciclase e consequentemente a produção de cAMP. Outros mensageiros secundários devem, portanto, estar levando a ativação da transcrição do gene da gp 80 em resposta aos pulsos de CAMP. A participação da proteína quinase $\mathrm{C}$ e/ou $\mathrm{Ca}^{2+}$ na regulação da transcrição de genes regulados por cAMP tem sido proposta (Ginsburg e

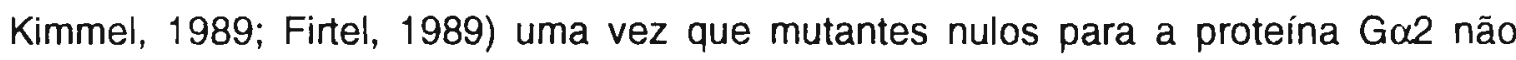
expressam vários destes genes incluindo o gene da gp80 (Coukell et al., 1983; Ma e Siu, 1990; Peters et al., 1991b). Por outro lado, concentrações altas e constantes de cAMP causam a diminuição dos niveis do mRNA para gp80. Nossos dados mostram que este mRNA é relativamente estável em células competentes para agregação, a menos que estas sejam submetidas a este tratamento. Em resumo nós verificamos que a expressão do mRNA da gp80 era induzida por cAMP em concentrações micromolares enquanto que concentrações milimolares causavam a diminuição dos niveis deste mRNA.

A diminuição dos níveis de mRNA para gp80 está associada à "downregulation" do receptor de cAMP.

Quando células de Dictyostelium são estimuladas com baixas concentrações de cAMP, a ocupação do receptor leva à ativação da adenilato ciclase e a um aumento 
correspondente nos niveis de cAMP intracelular. Há vários anos atrás Klein e Juliani (1977) demonstraram que estimulação de células competentes para agregação com altas concentrações de CAMP resulta na perda de sítios receptores para CAMP da superficie, um fenômeno conhecido como "down-regulation" do receptor. Incubação de células com 0,1 mM de cAMP por 30 minutos resulta em perda de aproximadamente $70 \%$ da atividade de ligação do receptor da superfície celular enquanto que $1 \mathrm{mM}$ de cAMP pode induzir quase $90 \%$ de perda dos receptores. A necessidade de concentrações tão altas de cAMP reflete a atividade da fosfodiesterase extracelular que restringe severamente a vida média do cAMP adicionado, uma vez que concentrações muito menores de cAMP podem efetivamente induzir a "downregulation" do receptor em um mutante que não possui a fosfodiesterase (Klein, 1979). Os mecanismos de "down-regulation" não estão completamente elucidados mas parecem envolver fosforilação do receptor de cAMP (Lubs-Haukeness e Klein, 1982; Klein e Juliani, 1979; Klein et al., 1985) e a formação de uma forma de dissociação lenta do receptor (Klein, 1979). Dados recentes sugerem que o receptor deve permanecer na superfície da célula mas em uma forma incapaz de ligar o ligante (Tao e Klein, 1990) nos primeiros 30 minutos de incubação com cAMP e após este período deve ser internalizado e degradado (Van Haastert et al., 1992).

Os eventos bioquímicos que acompanham a "down-regulation" do receptor são desconhecidos. Em particular, não é claro se os mesmos mensageiros secundários gerados quando da ativação do receptor (por baixas concentrações de cAMP) são gerados em condições que levam à "down-regulation" (altas concentrações de cAMP). Nossos resultados demonstraram que condições que levam a "down-regulation" resultam na diminuição dos níveis de mRNA para gp80. Estas condições incluem tratamento de células competentes para agregação com $1 \mathrm{mM}$ de cAMP ou com 100 $\mu \mathrm{g} / \mathrm{ml}$ de ConA. ConA induz "down-regulation" do receptor, sem causar sua ativação. Portanto, aparentemente a ocupação do receptor (e portanto ativação deste) não é essencial para que o processo ocorra, mas sim que o receptor sofra "down-regulation". Além disso, estimulação das células com dibutiril-cAMP, um agonista fraco do receptor de CAMP mas que penetra nas células e pode ativar a proteína quinase dependente de cAMP (Oyama e Blumberg, 1986; Van Haastert e Kien, 1983) não foi eficiente em diminuir os niveis de mRNA para gp80. Em contraste, 2-desoxi-cAMP, que tem uma alta afinidade pelo receptor de CAMP da superficie e provoca a sua "down-regulation", mas que se liga fracamente a proteina quinase dependente de cAMP (Van Haastert e Kien, 1983), mostrou efeitos similares ao cAMP. Estas observações indicam que a via de transdução de sinal que leva à diminuição dos niveis de mRNA para gp80 em 
resposta a "down-regulation" do receptor não envolve mudanças nos niveis de cAMP intracelular. Similarmente, como já discutido, o aumento dos niveis de mRNA para gp80 quando células são estimuladas com baixas concentrações de cAMP também não requer mudanças nos niveis de cAMP intracelular. Portanto, apesar de ambos os fenômenos serem mediados pelo receptor de cAMP da superfície, tal mecanismo não parece ser mediado por acoplamento do receptor com a adenilato ciclase e sua subsequente ativação. Outros mensageiros secundários, como $\mathrm{Ca}^{2+}$, diacilglicerol, ou cGMP poderiam estar envolvidos já que a ativação do receptor parece estar ligada à produção de inositol trifosfato, às mudanças na concentração de $\mathrm{Ca}^{2+}$ e à ativação da guanilato ciclase (Newell et al., 1988; Firtel, 1991; Kimmel e Firtel, 1991; Van Haastert et al., 1991).

\section{A diminuição dos níveis de mRNA para gp80 é devida à desestabilização} da mensagem e parece requerer síntese de RNA e de proteínas.

Vários laboratórios têm estudado, em Dictyostelium, os efeitos de cAMP nos níveis de mRNAs específicos em diferentes estágios de desenvolvimento (Haribabu e Dottin, 1986; Oyama e Blumberg, 1986; Mann e Firtel, 1987; Mann e Firtel, 1989; Kimmel, 1987; Gerisch, 1987; Driscoll e Williams, 1987; Williams et al., 1980; Landfear et al., 1982; Chung et al., 1981; Mangiarotti et al., 1983; Peters et al., 1991b). Predominantemente, tais estudos documentaram mudanças na transcrição gênica (Driscoll e Williams, 1987; Williams et al., 1980; Landfear et al., 1982; Chung et al., 1981) ou aumento da estabilidade do mRNA (Mangiarotti et al., 1983). Os dados que obtivemos descrevem um efeito diferenciado de CAMP, mostrando que eventos mediados pelo receptor de cAMP da superfície resultam na desestabilização de um mRNA. Três linhas de evidências foram obtidas para apoiar esta conclusão: (1) células incubadas com alta concentração de CAMP mostraram uma diminuição relativamente rápida dos niveis de mRNA para gp80, mas mantiveram niveis normais de mRNA para actina; (2) a taxa de transcrição para o gene da gp80, determinada por ensaios de "run-off" nuclear, não foi reduzida por tratamento das células com esta concentração de cAMP e (3) experimentos de pulso e caça indicaram que tal tratamento leva a um aumento da taxa de degradação da mensagem. Mann e Firtel (1989) também mostraram que altas concentrações de cAMP levam a diminuição nos niveis do mRNA para gp80, contudo, eles não demonstraram que este efeito era devido a diminuição da meia-vida do mRNA. Em adição, foi reportado que altas concentrações de cAMP também causam uma diminuição dos niveis do mRNA para gp80 durante o programa de desdiferenciação, que neste caso, deve-se a desestabilização do mRNA (Chandrasekhar et al., 1990). 
A desestabilização do mRNA para gp80 foi detectada após aproximadamente 15 minutos de exposição ao cAMP, como revelaram os experimentos de medida dos niveis de mRNA em "Northem blots" e de pulso e caça. Este período pode refletir o tempo necessário para sintetizar uma proteína(s) que regula a estabilidade do mRNA para gp80. Esta hipótese é substanciada pela observação de que inibidores de síntese de RNA e proteina bloqueiam o efeito da estimulação com cAMP nos niveis de mRNA para gp80. Cada um dos dois inibidores de síntese protéica utilizados nestes experimentos tem um modo de ação distinto. Cicloeximida inibe o passo de elongação, enquanto que pactamicina inibe a formação do complexo de iniciação. Consequentemente, polissomos acumulam ou são desmontados pelos respectivos tratamentos. Kelly et al., (1987) mostraram que alguns mRNAs podem ser estabilizados por tratamento com cicloeximida mas não por pactamicina. Como arnbas as drogas preveniram a diminuição dos níveis de mRNA para gp80 induzida por cAMP, é pouco provável que isto reflita o estado dos polissomos após a inibição da síntese protéica. Juntos, os dados apóiam a hipótese de que estimulação com cAMP induz a expressão de uma proteína desestabilizadora de mRNA. Uma hipótese similar foi apresentada para explicar a desestabilização do mRNA para interleucina-1b induzida por glicocorticóide e o requerimento de síntese protéica para que isto ocorra (Lee et al., 1988). Nós também observamos que, apesar de cAMP não estimular o decaimento do mRNA para gp80 em células incubadas com cicloeximida e pactamicina, a taxa de perda do mRNA foi mais rápida quando estas drogas estavam presentes (mas nunca tão alta quanto quando cAMP era adicionado). O significado desta observação não é ainda claro, mas pode sugerir que síntese protéica também seja necessária para estabilizar o mRNA para gp80.

Envolvimento de $\mathrm{Ca}^{2+}$ e proteína quinase $\mathrm{C}$ na via de transdução de sinal que ativa a desestabilização do mRNA

A variação da estabilidade de mRNAs é uma alternativa à variação dos níveis de transcrição, no controle da expressão gênica, sendo um processo altamente específico e de importância singular quando as células necessitam alterar rapidamente o seu padrão de síntese protéica em resposta a sinais ambientais específicos (para revisão veja Saini et al., 1990; Atwater et al., 1990). Contudo, os mecanismos pelos quais as células transduzem estes sinais para desencadear a desestabilização de mRNAs especificos não são bem compreendidos. Como discutimos anteriormente, em Dictyostelium discoideum, tanto a sintese quanto a estabilidade de mRNAs são afetadas por contato celular e cAMP mas os elementos regulatórios envolvidos na modulação destes eventos são pouco conhecidos. Na tentativa de elucidar o 
mecanismo pelo qual a "down-regulation" do receptor de cAMP leva à desestabilização do mRNA para gp80 nós realizamos vários experimentos com o objetivo de identificar os possíveis mensageiros secundários envolvidos neste processo. Os dados indicam que um influxo de $\mathrm{Ca}^{2+}$ através da membrana plasmática parece mediar a desestabilização.

Condições que causam a "down-regulation" do receptor de cAMP induzem um aumento significativo de tomada de $\mathrm{Ca}^{2+}$ paralelamente à diminuição dos niveis no mRNA para gp80. Oscilações de cáicio já foram estudadas ern Dictyostelium discoideum em resposta a baixas concentrações de cAMP (para revisão ver Wurster et al., 1990). Neste caso, concentrações micromulares de cAMP induzem tomada de $\mathrm{Ca}^{2+}$ do meio após aproximadamente 10 segundos da estimulação de células competentes para agregação (Wick et al., 1978; Bumaıın et al., 1984; Europe-Finner e Newell, 1985; Milne e Coukell, 1991). A resposta apresenta um máximo após aproximadamente 30 segundos e segue-se então um período de liberação lenta por 1 minuto ou mais (Bumann et al., 1984). Nossas medidas de tomada de $\mathrm{Ca}^{2+}$ após estimulação das células com concentrações milimolares de cAMP indicam um aumento contínuo de $\mathrm{Ca}^{2+}$ e sua retenção intracelular durante os 60 minutos do experimento. Tratamento das células com ConA que, como já discutido, resulta em "downregulation" do receptor e desestabilização do mRNA para gp80, também induz um influxo de $\mathrm{Ca}^{2}+$ similar ao observado após tratamento com $1 \mathrm{mM}$ de cAMP. A natureza dos possiveis canais que mediam tomada de $\mathrm{Ca}^{2+}$ em Dictyostelium é ainda desconhecida, apesar de alguns estudos terem sido realizados neste sentido. Em células estimuladas com concentrações micromolares de cAMP, o sistema de transporte de $\mathrm{Ca}^{2+}$ não parece ser um canal ativado por voltagem ou um trocador de $\mathrm{Na}^{+} / \mathrm{Ca}^{2+}$, e é insensível a diferentes bloqueadores de canal ativos em células de mamíferos (Milne e Coukell, 1991). Nossas tentativas de inibir o influxo de $\mathrm{Ca}^{2+}$ utilizando $\mathrm{La}^{3+}$ e $\mathrm{Cd}^{2+}$, descritos por Milne e Coukell (1991) como um fraco inibidor da tomada de $\mathrm{Ca}^{2+}$ induzida por CAMP, ou utilizando rutênio vermelho, um bloqueador de canal mais efetivo, foram sem sucesso. Os dados sugerem que o sistema de transporte responsivo a concentrações micromolares de cAMP pode não ser similar ao ativado por concentrações que levam à "down-regulation" do receptor.

Evidências adicionais corroboram a hipótese de que a tomada de $\mathrm{Ca}^{2+}$ estimulada por cAMP media a desestabilização do mRNA para gp80. O ionóforo de cálcio A23187 causa aumento de cálcio intracelular (Aeckerle e Malchow, 1989) e como mostramos, tal tratamento desestabiliza seletivamente a mensagem para gp80, com uma cinética semelhante àquela verificada no tratamento com $1 \mathrm{mM}$ de CAMP. 
Este efeito é ainda mais pronunciado quando $\mathrm{Ca}^{2+}$ é adicionado ao meio, condição que aumenta a tomada de cálcio.

Experimentos utilizando TMB-8 e $\mathrm{LiCl}$ indicaram que é um influxo de $\mathrm{Ca}^{2+}$ através da membrana plasmática, e não um aumento de $\mathrm{Ca}^{2}+$ intracielular devido à liberação de cálcio de compartimentos intracelulares, que induz desestabilização do mRNA para gp80. Apesar do mecanismo de ação do TMB-8 não ser conhecido, esta droga tem sido frequentemente utilizada em vários sistemas, incluindo Dictyostelium (Blumberg et al., 1989), para se estudar o envolvimento de compartimentos intracelulares de $\mathrm{Ca}^{2+}$ em eventos de transdução de sinal. Nenhum efeito na desestabilização da mensagem induzida por cAMP foi observado quando células foram tratadas com TMB-8. $\mathrm{LiCl}$ inibe vários passos da desfosforilação de $\mathrm{IP}_{3} \mathrm{em}$ Dictyostelium (Van Lookeren Campagne et al., 1988), induz a expressão de genes prétalo e inibe a expressão de genes pré-esporo (Peters et al., 1989). Este composto também não foi capaz de inibir a habilidade de altas concentrações de cAMP levarem à degradação do mRNA para gp80. Estes resultados indicam que a liberação de cálcio de compartimentos intracelulares não media este fenômeno. 8-CPT-cAMP, um derivado de cAMP, que ao contrário deste diminui os niveis de $\mathrm{IP}_{3}$ (Peters et al., 1991a), também foi capaz de induzir a desestabilização do mRNA para gp80, confirmando os resultados acima. Concluímos portanto que a "down-regulation" do receptor quimiotático de CAMP, que ocorre com o tratamento das células com altas concentrações de cAMP, induz um influxo de cálcio e que este influxo ativa os eventos envolvidos na degradação do mRNA para gp80.

Os eventos bioquímicos subsequentes ao influxo de $\mathrm{Ca}^{2+}$ precisam ser ainda elucidados. Como um influxo de $\mathrm{Ca}^{2}+$ levaria a expressão gênica específica é uma questão intrigante. No momento estamos considerando um papel para proteína quinase $\mathrm{C}$ neste processo. Uma atividade enzimática com propriedades de proteina quinase $C$ foi descrita em Dictyostelium discoideum (Lüderus et al., 1989; Ravid e Spudich, 1992). Staurosporin é um potente inibidor de proteína quinase C (Ruegg e Burgess, 1989), e apesar de outros efeitos da droga terem sido reportados (FujitaYamaguchi e Kathuria, 1988; Nakano et al., 1987), a sensibilidade de processos celulares a tratamento com staurosporin sugere um papel para proteína quinase $C$. Nós observamos que staurosporin causa uma diminuição dos níveis de mRNA para gp80, mas não está ainda claro se isto reflete um efeito secundário da droga, ou uma ação complexa da proteína quinase $C$ no balanço transcrição/estabilidade da mensagem. No entanto, staurosporin reduziu significantemente a habilidade de tratamento com cAMP levar à desestabilização do mRNA, mesmo durante o período 
em que incubação só com a droga praticamente não alterou os niveis de mRNA para gp80.

Um papel para proteína quinase $C$ na regulação de estabilidade de mRNAs tem sido sugerido em outros sistemas (Takahama e Singer, 1992; Iwai et al., 1991). Alguns trabalhos postulam um papel para proteína quinase $C$ utilizando ésters de forbol, que promovem estabilização ou desestabilização de diferentes mensagens (Wager e Assoian, 1990; Parks et al., 1992). O ester de forbol PMA não alterou a desestabilização do mRNA para gp80 induzida por cAMP. No entanto, apesar de PMA estimular a atividade de proteína quinase $\mathrm{C}$ em Dictyostelium in vitro (Lúderus et al., 1989) ativação de proteína quinase $C$ in vivo não foi confirmada em Dictyosteliunı (Claudette Klein, comunicação pessoal). Estudos adicionais serão necessários para c.jtermos evidências definitivas de um papel para proteína quinase $\mathrm{C}$ neste processo, mas até que esta enzima seja definitivamente identificada e caracterizada, nós teremos que nos limitar a utilização de drogas como staurosporin para implicarmos esta quinase em processos variados.

Em resumo, os resultados descritos neste trabalho indicam que quando o receptor de cAMP sofre "down-regulation" ocorre um influxo de $\mathrm{Ca}^{2+}$ e que este influxo ativa a degradação do mRNA para gp80. Fosforilação por proteína quinase $\mathrm{C}$ também pode estar envolvida neste processo. Recentemente foi demonstrado que o tratamento prolongado das células com altas concentrações de cAMP causa uma rápida diminuição dos níveis do mRNA do receptor de cAMP (Van Haastert et al., 1992). Uma vez que o mRNA do receptor é regulado de uma forma similar ao mRNA da gp80, seria interessante investigar se estes e outros genes são regulados através das mesmas vias de transdução de sinal.

O mRNA da gp80 pode ser desestabilizado em outras fases do ciclo de vida

A observação de que o mesmo composto (cAMP) pode levar a dois processos opostos dependendo da maneira que é apresentado à célula é pouco usual. Baixas doses, na forma de pulsos de cAMP, resultam em níveis elevados do mRNA para gp80, refletindo um aumento da transcrição. Doses maiores de cAMP levam à rápida perda do mRNA, resultando na desestabilização deste. Esta regulação dupla dos niveis de mRNA para gp80 se correlacionam bem, no entanto, com os eventos que acompanham o desenvolvimento da ameba. Durante a fase inicial do ciclo de desenvolvimento, os niveis de mRNA para gp80 aumentam enquanto as células produzem pulsos de cAMP e desenvolvem competência para agregação (Noegel et al., 1986; Siu et al., 1988; Juliani et al., 1990; este trabalho). Experimentos de "run-off" 
nuclear indicam que este aumento reflete mudanças na transcrição do gene. Quando as células terminam o programa de agregação e começam a formar 0 pseudoplasmódio, o mRNA para gp80 não é detectado, período onde a proteína gp80 também desaparece da superfície da célula (Browne et al., 1989; Sadeghi et al., 1988). Durante este estágio de transição, os niveis do receptor de cAMP da superfície também diminuem (Greene e Newell, 1975; Klein e Juliani, 1979). É possível que esta diminuição reflita a "down-regulation" do receptor induzida por altas concentrações de CAMP no micro-ambiente do receptor (Klein e juliani, 1979) uma vez que concentrações locais altas de CAMP são esperadas na fase pós-agregação (Sadeghi et al., 1987; Firtel et al., 1989). Deste modo é provável que os eventos descritos neste trabalho reflitam as bases para mudanças nos niveis de mRNA para gp80 que ocorrem durante a transição da fase de agregação para a formaçáo do pseudoplasmódio. Também é interessante notar que o mRNA para gp80 reacumula transientemente durante o início da culminação em células destinadas a se tornar esporos (Browne et al., 1989). Experimentos também sugerem que receptores de cAMP da superfície celular podem ser expressos no final do desenvolvimento, e que gradientes de CAMP podem influenciar o desenvolvimento do organismo neste período (Firtel, 1991). Portanto, altos níveis de cAMP extracelular possam talvez mediar a diminuição dos niveis de mRNA para gp80 em células pré-esporos quando estas se diferenciam em células esporo maduras.

Com o objetivo de iniciamos um estudo mais detalhado sobre o processo de desestabilização do mRNA da gp80 durante o desenvolvimento nós obtivemos uma linhagem de Dictyostelium discoideum (T80-SUC) que expressa constitutivamente um CDNA para gp80 contendo um fragmento do gene SUC de levedura. A utilização desta quimera foi necessária para podermos distinguir o mRNA exógeno do mRNA transcrito a partir do gene natural da gp80 durante a fase de agregação. Os dados mostram que - mRNA correspondente a quimera gp80-SUC, quando expresso em células competentes para agregação era susceptivel a desestabilização induzida por altas concentrações de cAMP do mesmo modo que o mRNA da gp80. Como era esperado, a desestabilização induzida por cAMP não foi verificada durante a fase de crescimento da linhagem T80-SUC, uma vez que estas células não expressam o receptor de CAMP. Por outro lado, as células vegetativas possuem os elementos necessários para levar à desestabilização da mensagem desde que a concentração de $\mathrm{Ca}^{2}+$ intracelular seja artificialmente aumentada. No entanto, estes experimentos não eliminam a possibilidade de que elementos que precedem este evento sejam regulados pelo desenvolvimento. Uma proteína $G$ poderia, por exemplo, estar acoplando o receptor de 
CAMP a um canal de cálcio e ser por sua vez regulada pelo desenvolvimento. Já foi demonstrado que a subunidade $G \alpha 1$ em Dictyostelium é expressa em células vegetativas e durante o desenvolvimento até a fase de agregação. A subunidade $\mathrm{G} \alpha 2$, no entanto é expressa preferencialmente durante a fase de agregação (Kumagai et al., 1989) e poderia portanto ser excluida deste processo. Futuras investigações para compreendermos melhor a regulação da estabilidade do mRNA da gp80 pelo desenvolvimento incluem a análise dos níveis do mRNA gp80-SUC ao longo de todo o desenvolvimento e a obtenção de linhagens que co-expressem o cDNA do receptor de CAMP CAR1 e o cDNA gp80-SUC. Em adição, como a inserção do fragmento SUC no cDNA da gp80 não afetou as suas propriedades quanto a estabilidade em resposta ao CAMP ou ionóforo de cálcio, poderemos utilizar esta quimera no estudo das características moleculares do mPiNA da gp80 que lhe conferem este importante modo de regulação. É interessante observar que o cDNA da gp80 possui a sequência AUUUA, que funciona como uma sequência consenso desestabilizadora, encontrada dentro de uma região rica em Us na porção $3^{\prime}$ não codificadora de vários mRNAs instáveis (para revisão ver Sachs, 1993). Todas estas linhas de investigação propostas deverão aprofundar a compreensão sobre o mecanismo pelo qual cAMP leva à degradação do mRNA e o papel deste fenômeno na biogênese do organismo multicelular. 


\section{V - REFERÊNCIAS BIBLIOGRÁFICAS}

Aeckerle, S. e Malchow, D. (1989) Calcium regulates cAMP-induced potassium ion efflux in Dictyostelium discoideum. Biochem. Biophys. Acta. 1012, 196-200.

Atwater, J. A., Wisdom, R. e Verma, I. M. (1990) Regulated mRNA stability. Annu. Rev. Genet. 24, 519-541.

Eer'ss, M. e Kay, R. (1990) Combinatorial control of cell-differentiation by CAMP and DIF-1 during development of Dictyostelium discoideum. Development 110, 977-984.

Beug, H., Katz, F. E. e Gerisch, G. (1973) Dynamics of antigenic membrane sites relating to cell aggregation in Dictyostelium discoideum. J. Cell. Biol. 56, 647-658.

Blumberg, D. D., Comer, J. F. e Walton, E. M. (1989) $\mathrm{Ca}^{2+}$ antagonists distinguish different requirements for CAMP-mediated gene expression in the cellular slime mold, Dictyostelium discoideum. Differentiation 41, 14-21.

Brawerman, G. (1987) Determinants of messenger RNA stability. Cell 48, 5-6.

Brenner, M. e Thomas, S. D. (1984) Caffeine blocks activation of cAMP synthesis in Dictyostelium discoideum. Dev. Biol. 101, 136-146.

Browne, L. H., Sadeghi, H., Blumberg, D., Williams, K. L. e Klein, C. (1989) Reexpression of 117 antigen, a cell surface glycoprotein of aggregating cells, during terminal differentiation of Dictyostelium discoideum. Development 105, 657-664.

Bumann, J., Wurster, B. e Malchow, D. (1984) Attractant-induced changes and oscillations of the extracellular $\mathrm{Ca}^{++}$concentration in suspensions of differentiating Dictyostelium cells. J. Cell Biol. 98, 173-178.

Ceccarelli, A., Mahbubani, H. e Williams, J. G. (1991) Positively and negatively acting signals regulating stalk cell and anterior-like cell differentiation in Dictyostelium. Cell 65, 983-989. 
Chandrasekhar, A., Rotman, M., Kraft, B. e Soll, D. R. (1990) Developmental mechanisms regulating the rapid decrease in a cohesion glycoprotein mRNA in Dictyostelium function primarily at the level of mRNA degradation. Dev. Biol. 141, 262269.

Chisholm, R., Barklis, E. e Lodish, H. (1984) Mechanism of sequential induction of celltype specific mRNAs in Dictyostelium differentiation. Nature $310,67$.

Coukell, M. B., Lappano, S. e Cameron, A. M. (1983) Isolation arıd characterization of CAMP unresponsive (frigid) aggregation-deficient mutants of Liciyostelium discoideum. Dev. Genet. 3, 282-297.

Chung, S., Landfear, S. M., Blumberg, D. D., Cohen, N. S. e Lodish, H. F. (1981) Synthesis and stability of developmentally regulated Dictyostelium mRNAs are affected by cell-cell contact and cAMP. Cell 24, 785-797.

Darmon, M., Barrand, P., Brachet, P., Klein, C. e da Silva, L. H. (1977) Chemotactic signals induce cell differentiation in Dictyostelium discoideum. Dev. Biol. 58, 174-184.

Darmon, M., Brachet, P. e da Silva, L. H. (1975) Chemotactic signals induce cell differentiation in Dictyostelium discoideum. Proc. Natl. Acad. Sci. USA 72, 3163-3166.

Darnell, J. E., Lodish, H. e Baltimore, D. (1990) Molecular Cell Biology, 2a ed. Scientific American Books.

da Silva, A. M. e Klein, C. (1989) Characterization of a glycosyl-phsphatidylinositol degrading activity in Dictyostelium discoideum membranes. Exp. Cell Res. 185, 464472.

da Silva, A. M. e Klein, C. (1990) Cell adhesion in transformed Dictyostelium discoideum cells: expression of gp80 and its biochemical characterization. Dev. Biol. $140,139-148$.

Desbarats, L., Lam, T. Y., Wong, L. M. e Siu, C.-H. (1992) Identification of a unique cAMP-response element in the gene encoding the cell adhesion molecule gp80 in Dictyostelium discoideum. J. Biol. Chem. 267, 19655-19664. 
Devreotes, P. (1989) Dictyostelium discoideum: a model system for cell-cell interactions in development. Science 245:1054-1058.

Devreotes, P. N. e Sherring, J. A. (1985) Kinetics and concentration dependence of reversible cAMP-induced modification of the surface cAMP receptor in Dictyostelium. J. Biol. Chem. 260, 6378-6384.

Dohilman, H. G., Caron, M. G. e Lefkowitz, R. J. (1987) A family of receptors coupled to guanine nucleotide regulatory protein. Biochemistry 26, 2657-2664.

Driscoll, D. M. e Williams, J. G. (1987) Two divergently transcribed genes of Dictyostelium discoideum are cyclic AMP-inducible and co-regulated during development. Mol. Cell. Biol. 7, 4482-4489.

Early, A. E. e Williams, J. G. (1988) A Dictyostelium prespore-specific gene is transcriptionally repressed by DIF in vitro. Development, 103, 519-524.

Early, A. E., Williams, J. G., Meyer, H. E., Por, S. B., Smith, E., Williams, K. L. e Gooley, A. A. (1988) Structural characterization of Dictyostelium discoideum presporespecific gene D19 and of its product, cell surface glycoprotein PsA. Mol. Cell. Biol. 8, 3458-3466.

Europe-Finner, G. N. e Newell, P. C. (1984) Inhibition of cyclic GMP formation and aggregation in Dictyostelium by the intracellular $\mathrm{Ca}^{2+}$ antagonist TMB-8. FEBS lett. 171, 315-319.

Europe-Finner, G. N. e Newell, P. C. (1985) Calcium transport in the cellular slime mold Dictyostelium discoideum. FEBS lett. 186,70-74.

Europe-Finner, G. N. e Newell, P. C. (1986) Inositol 1,4,5-trisphosphate induces calcium release from a non-mitochondrial pool in amoebae of Dictyostelium. Biochem. Biophys. Acta 887, 335-340.

Europe-Finner, G. N. e Newell, P. C. (1987) Cyclic AMP stimulates accumulation of inositol trisphosphate in Dictyostelium. J. Cell Sci. 87, 221-229. 
Faix, J., Gerisch, G. e Noegel, A. A. (1990) Constitutive overexpression of the contact site A glycoprotein enables growth-phase cells of Dictyostelium discoideum to aggregate. The Embo J. 9, 2709-2716.

Feinberg, A. e Vogelstein, B. (1983) A technique for radiolabeling DNA restriction endoriuclease fragments to high specific activity. Anal. Biochem. 132, 6-13.

Firtel, R. A. (1991) Signal transduction pathways controlling multicellular development in Dictyustelium. Trends in Genet. 7, 381-388.

Firtel, R. A., V an Haastert, P. J. M., Kimmel, A. R. e Devreotes, P. N. (1989) G protein linked signal transduction pathways in development: Dictyostelium as an experimental system. Cell 58, 235-239.

Fujita-Yamaguchi, Y. e Kathuria, S. (1988) Characterization of receptor tyrosinespecific protein kinases by the use of inhibitors. Staurosporin is a 100-times more potent inhibitor of insulin receptor than IGF-I receptor. Biochem. Biophys. Res. Comm. $157,955-962$.

Gao, E. N., Shier, P. e Siu, C.-H. (1992) Purification and partial characterization of a cell adhesion molecule (gp150) involved in postaggregation stage cell-cell binding in Dictyostelium discoideum. J. Biol. Chem. 267, 9409-9415.

Gerisch, G. (1980) Univalent antibody fragments as tools for the analysis of cell interactions in Dictyostelium discoideum. Curr.Topics Dev.Biol. 14:243-270.

Gerisch, G. (1987) Cyclic AMP and other signals controlling cell development and differentiation in Dictyostelium. Ann. Rev. Biochem. 56, 853-879.

Gilman, A. G. (1987) G proteins: transducers of receptor-generated signals. Annu. Rev. Biochem. 56, 615-649.

Ginsburg, G. e Kimmel, A. R. (1989) Inositol trisphosphate and diacylglicerol can differentially modulate gene expression in Dictyostelium. Proc. Natl. Acad. Sci. USA. 86, 9332-9336. 
Gonzalez, G. A., Yamamoto, K. K., Fischer, W. H., Karrs, D., Manzel, P., Biggs, W., III, Vale, W. W. e Montminy, M. R. (1989) A cluster of phosphorylation sites on the cyclic AMP regulated nuclear factor CREB predicted by its sequence. Nature 337, 749-752.

Hanahan, D. (1985) Techniques for transformation of E. coli in DNA Cloning, vol.1, a practical approach (Glover, D. M., ed.), IRL Press.

Haribabu, B. e Dottin, R. P. (1986) Pharmacological characterization of cAMP receptors mediating gene regulation in Dictyostelium discoideum. Mol. Cell. Biol. 6: 2402-2408.

tarloff, C., Gerisch, G. e Noegel, A. A. (1989) Selective elimination of the contact site A protein of Dictyostelium discoideum by gene disruption. Genes \& Develop. 3, 20112019.

Harlow, E. e Lane, D. (1988) Antibodies, a laboratory manual. Cold Spring Harbor Laboratory, Cold Spring Harbor, N.Y.

Harwood, A. J., Hopper, N. A., Simon, M.-N., Driscoll, D. M., Veron, M. e Williams, J. G. (1992) Culmination in Dictyostelium is regulated by the cAMP-dependent protein kinase. Cell 69, 615-624.

Hildebrandt, M. e Nellen, W. (1992) Differential expression of sense and antisense transcripts from the Dictyostelium EB4 gene locus: implications on antisense mediated regulation of RNA stability. Cell 69, 197-204.

Homahn, H. P., Bozzaro, S., Yoshida, M., Merkl, R. e Gerisch, G. (1987) Two-step glycosilation of the contact site A protein of Dictyostelium discoideum and transport of an incompletely glycosilated form to the cell surface. J. Biol. Chem. 262:16618-16624.

Huynh, T. V., Young, R. A. e Davis, R. W. (1985) Constructing and screening cDNA libraries in $\lambda$ gt10 and $\lambda$ gt11 in DNA cloning, vol.1, a practical approach (Glover, D. M., ed.), IRL Press.

Iwai, Y., Bickel, M., Pluznik, D. H. e Cohen, R. B. (1991) Identification of sequences within the murine granulocyte-macrophage colony stimulating factor mRNA 3'- 
untranslated region that mediates mRNA stabilization induced by mitogen treatment of EL-4 thymoma cells. J. Biol. Chem. 266, 17959-17965.

Janssens, P. M. W. e Van Haastert, P. J. M. (1987) Molecular basis of transmembrane signal transduction in Dictyostelium discoideum. Microbiol. Rev. 51, 396-418.

Johnson, L. M., Bankaitis, V. A. e Emr, S. D. (198i) Distinct sequence determinants direct intracellular sorting and modification of a yeast vacuolar protease. Cell 48, 875885 .

Juliani, M. H. e Klein, C. (1978) A biochemical study of the effects of cAMP pulses on aggregateless mutants of Dictyostelium discoideum. Develop. Biol. 62,162-172.

Juliani, M. H. e Klein, C. (1977) Calcium ions effects on cyclic adenosine $3^{\prime}: 5^{\prime}$ monophosphate bindings to the plasma membrane of Dictyostelium discoideum. Biochem. Biophys. Acta 497, 369-376.

Juliani, M. H. e Klein, C. (1981) Photoaffinity labeling of the cell surface adenosine 3':5'monophosphate receptor of Dictyostelium discoideum and its modification in downregulated cells. J. Biol. Chem. 256, 613-619.

Juliani, M. H., Souza, G. M. e Klein, C. (1990) cAMP stimulation of Dictyostelium discoideum destabilizes the mRNA for 117 antigen. J. Biol. Chem. 265, 9077-9082.

Kamboj, R. K., Gariepy, J. e Siu, C.-H. (1989) Identification of an octapeptide involved in homophilic interaction of the cell adhesion molecule gp80 of Dictyostelium discoideum. Cell 59, 615-625.

Karin, M. (1992) Signal transduction from cell surface to nucleus in development and disease. FASEB J. 6, 2581-2590.

Kelly, R. B., Cozzarelli, N. R., Deutscher, M. P., Lehman, I. R. e Kornberg, A. (1970) Replication of duplex deoxyribonucleic acid by polymerase at a single strand break. J. Biol. Chem. 245, 39. 
Kelly, R., Kelly, R. J. e Ennis, H. L. (1985) Dictyostelium discoideum mRNAs developmentally regulated during spore germination have short half-lives. Mol. Cell. Biol. 5, 133-139.

Kelly, R., Shaw, D. R. e Ennis, H. L. (1987). Role of protein synthesis in decay and accumulation of mRNA during spore germination in the cellular slime mold Dictyostelium discoideum. Mol. Cell. Biol. 7: 799-805.

Kessin, R. H., Orlow, S. J., Shapiro, R. I. e Franke, J. (1979) Binding of inhibitor alters kinetic and physical properties of extracellular cyclic AMP phosphodiesterase from Dictyostelium discoideum. Proc. Natl. Acad. Sci. USA 76, 5450-5454.

Kimmel, A. R. (1987) Different molecular mechanisms for cAMP regulation of gene expression during Dictyostelium development. Dev. Biol. 122, 163-171.

Kimmel, A. R. e Firtel, R. A. (1982) in The development of Dictyostelium discoideum (Loomis, W. F., ed.) pp. 233-324, Academic Press, New York.

Kimmel, A. R. e Firtel, R. A. (1991) cAMP signal transduction pathways regulating development of Dictyostelium discoideum. Current Opinion in Genet. and Dev. 1, 383390.

Klein, C. (1979) A slowly dissociating form of the cell surface cyclic adenosine 3':5'monophosphate receptor of Dictyostelium discoideum. J. Biol. Chein. 254: 1257312578.

Klein, C. e Juliani, M. H. (1977) cAMP-induced changes in cAMP-binding sites on $D$. discoideum amoebae. Cell 10, 329-335.

Klein C., Lubs-Haukeness, J. e Simons, S. (1985) CAMP induces a rapid and reversible modification of the chemotactic receptor in Dictyostelium discoideum. J. Cell. Biol. 100, 715-720.

Klein, P. S., Sun, T. J., Saxe III, C. L., Kimmel, A. R., Johnson, R. L. e Devreotes, P. N. (1988) A chemoattractant receptor controls development in Dictyostelium discoideum. Science 241, 1467-1472. 
Klein, P., Theibert, D., Fontana, D. e Devreotes, D. N. (1985) Identification and cyclic AMP induced modification of the cAMP receptor in Dictyostelium discoideum. J. Biol. Chem. 260, 1757-1764.

Klein, P., Vaughan, R., Borleis, J., Devreotes, P. N. (1987) The surface cyclic AMP receptor in Dictyostelium. J. Biol. Chem. 262, 358.

Klionski, D. J., Banta, L. M. e Emr, S. D. (1988) intracellular sorting and processing of a yeast vacuolar hydrolase: proteinase A propeptide contains vacuolar targetting information. Mol. Cell. Biol. 8, 2105-2116.

Knecht, D.A., Fuller, D.L. e Loomis, W.F. (1987) Surface glycoprotein, gp24, involved in early adhesion of Dictyostelium discoideum. Dev.Biol. 121:277-283.

Kumagai, A., Pupillo, M., Gundersen, R., Miake-Lye, R., Devreotes, P. N. e Firtel, R. A. (1989) Regulation and function of $\mathrm{G}_{\alpha}$ protein subunits in Dictyostelium. Cell 57, 265275.

Kwong, L., Sabolewski, A. e Weeks, G. (1988) The effect of cAMP on differentiation inducing factor (DIF)-mediated formation of stalk cells in low-cell-density monolayers of Dictyostelium discoideum. Differentiation 37, 1-6.

Laemmli, U. K. (1970) Cleavage of structural proteins during assembly of the head of the bacteriophage $\mathrm{T}_{4}$. Nature 226, 680-685.

Landfear, S. M., Lefebvre, P., Chung, S. e Lodish, H. F. (1982) Transcriptional control of gene expression during development of Dictyostelium discoideum. Mol. Cell. Biol. 2: 1417-1426.

Lee, S. W., Tsou, A., Chan, H., Thomas, J., Petrie, K., Eugui, E. M. e Allison, A. C. (1988) Glucocorticoids selectively inhibit the transcription of the interleukin $1 \beta$ gene and decrease the stability of interleukin $1 \beta$ mRNA. Proc. Natl. Acad. Sci. USA 85, 12041208. 
Loomis, W. F. (1982) The Development of Dictyostelium discoideum. Academic Press, New york.

Lubs-Haukeness, J. e Klein, C. (1982) Cyclic nucleotide-dependent phosphorylation in Dictyostelium discoideum amoebae. J. Biol. Chem. 257, 12204-12208.

Ludérus, M. E. E., Van der Most, R. G., Otte, A. P. e Van Driel, R. (1989) A protein kinase C-related enzyme activity in Dictyostelium discoideum. FEBS Lett. 253, 71-75.

Ma, P. C.-C. e Siu, C.-H. (1990) A pharmacologically distinct cyclic AMP receptor is responsible for the regulation of gp80 expression in Dictyostelium discoideum. Mol. Cell. Biol. 10, 3297-3306.

Mangiarotti, G., Ceccarelli, A. e Lodish, H. F. (1983) Cyclic AMP stabilizes a class of developmentally regulated Dictyostelium discoideum mRNAs. Nature 301, 616-618.

Mangiarotti, G., Giorda, R., Ceccarelli, A. e Perlo, C. (1985) mRNA stabilization controls the expression of a class of developmentally regulated genes in Dictyostelium discoideum. Proc. Natl. Acad. Sci. 82, 5786-5790.

Maniatis, T., Fritsch, E. F., Sambrook, J. (1982) Molecular Cloning, a laboratory manual. Cold Spring Harbor Laboratory, Cold Spring Harbor, N.Y.

Mann, S. K. O. e Firtel, R. A. (1987) Cyclic AMP regulation of early gene expression in Dictyostelium discoideum: mediation via the cell surface cyclic AMP receptor. Mol. Cell. Biol. 7, 458-469.

Mann, S. K. O. e Firtel, R. A. (1989) Two-phase regulatory pathway controls cAMP receptor-mediated expression of early genes in Dictyostelium. Proc. Natl. Acad. Sci. USA 86, 1924-1928.

Manrow, R. E. e Jacobson, A. (1988) mRNA decay rates in late-developing Dictyostelium discoideum cells are heterogenous and cyclic AMP does not act directly to stabilize cell-type-specific mRNAs. Mol. Cell. Biol. 8, 4088-4097. 
Marin, F. (1976) Regulation of development in Dictyostelium discoideum. I. Initiation of the growth to development transition by amino-acid starvation. Dev. Biol. 48, 110.

Mehdy, M e Firtel, R. (1985) A secreted factor and CAMP jointly regulate cell-type specific gene expression in Dictyostelium discoideum. Mol. Cell. Biol. 5, 705.

Meier, K. e Klein, C. (1988) An unusual protein kinase phosphorylates the chemotactic receptor of Dictyostelium discoideurn. Proc. Natl. Acad. Sci. USA 85, 2181-2185.

Milne, J. L. e Coukell, M. B. (1991) $\mathrm{A} \mathrm{Ca}^{2+}$ transport system associated with the plasma membrane of Dictyostelium discoideum is activated by different chemoattractant receptors. J. Cell Biol. 1i2, 103-110.

Muller, K. e Gerisch, G. (1978) A specific glycoprotein as the target site of adhesion blocking Fab in aggregating Dictyostelium cells. Nature 274, 445-449.

Nakano, H., Kobayashi, I., Takahashi, I., Tamaoki, T., Kuzuu, Y. e Iba, H. (1987) Staurosporin inhibits tyrosine specific protein kinase activity of Rous sarcoma virus transforming protein p60. J. Antibiotics 40, 706-708.

Nellen, W., Datta, S., Reymond, C., Silvertsen, A., Mann, S., Crowley, T. e Firtel, R. A. (1987) Molecular biology in Dictyostelium: tools and applications. Methods in Cell Biology 28, 87-100.

Newell, P. C., Europe-Finner, G. N., Small, N. V. e Liu, G. (1988) Inositol phosphates, G-proteins and ras genes involved in chemotactic signal transduction of Dictyostelium. J. Cell. Sci. 89, 123-127.

Noegel, A., Gerisch, G., Stadler, J. e Westphal, M. (1986) Complete sequence and transcript regulation of a cell adhesion protein from aggregating Dictyostelium cells. EMBO J. 5, 1473-1476.

Oyama, M. e Blumberg, D. D. (1986) Interaction of CAMP with the cell surface receptor induces cell-type-specific mRNA accumulation in Dictyostelium discoideum. Proc. Natl. Acad. Sci. USA 83, 4819-4823. 
Pannbacker, R. G. e Bravard, L. J. (1972) Phosphodiesterase in Dictyostelium discoideum and the chemotactic response to cyclic adenosine monophosphate. Science 175, 1014-1015.

Parks, W. C., Kolouziej, M. E. e Pierce, R. A. (1992) Phorbol ester-mediated downregulation of tropoelastin expression is controlled by a posttranscriptional mechanism. Biochemistry 31, 6639-6645.

Peters, D. J. M., Bominaar, A. A., Snaar-Jagalska, B. E., Brandt, R., Van Haastert, P. J. M., Ceccarelli, A., Williams, J. G. e Schaap, P. (1991a) Selective incluction of gene expression and second-messenger accumulation in Dictyostelium discoideum by the partial chemotactic antagonist 8-p-chlorophenylthioadenosine 3',5'-cyclic monophosphate. Proc. Natl. Acad. Sci. USA. 88, 9219-9223.

Peters, D. J. M., Cammans, M., Smit, S., Spek, W., Van Lookeren Campagne, M. M. e Schaap, P. (1991b) Control of cAMP-induced gene expression by divergent signal transduction pathways. Dev. Genetics 12, 25-34.

Peters, D. J. M., Van Lookeren Campagne, M. M., Van Haastert, P. J. M., Spek, W. and Schaap, P. (1989) Lithium ions induce prestalk-associated gene expression and inhibit prespore gene expression in Dictyostelium discoideum. J. Cell Science 93, 205210.

Pivi, A. M., Souza, G. M. e da Silva, A. M. (1993) Constitutive overexpression of the cell adhesion molecule gp80 in Dictyostelium discoideum. Resumos da XXII Reunião Anual da Sociedade Brasileira de Bioquímica e Biologia Molecular. P.53.

Rizzuto, R., Sandona, D., Porini, M., Marschalek, R., Dingerman, T. e Bisson, R. (1993) Structure of the promoter region of the gene encoding cytochrome $\mathrm{C}$ oxidase subunit $\mathrm{V}$ in Dictyostelium discoideum. Eur. J. Biochem. 211, 411-414.

Roesler, W. J., Vandenbark, G. R. e Hanson, R. W. (1988) cAMP and the induction of eukaryotic gene transcription. J. Biol. Chem. 263, 9063-9066.

Ross, F. M. e Newell, P. C. (1981) Streamers: chemotactic mutants of Dictyostelium with altered cGMP metabolism. Microbiology 127, 339-350. 
Rossier, C., Gerisch, G., Malchow, D. e Eckstein, F. (1979) Action of a slowly hydrolysable cyclic AMP analogue on developing cells of Dictyostelium discoideum. J. Cell Sci. 35, 321-338.

Ruegg, U. T. e Burgess, G. M. (1989) Staurosporin, K-252 and UCN-01: potent but nonspecific inhibitors of protein kinases. Trends in Pharmacol. Sci. 10, 218-220.

Sachs, A. B. (1993) Messenger RNA degradation in eukaryotes. Cell 74, 413-421.

Sadeghi, H., da Silva, A. M. e Klein, C. (1988a) Evidence that a glycolipid tail anchors antigen 117 to the plasma membrane of Dictyostelium discoideum cells. Proc. Natl. Acad. Sci. 85, 5512-5515.

Sadeghi, H., da Silva, A. M. e Klein, C. (1988b) Biosynthesis of 117 antigen: a cell cohesion molecule in Dictyostelium discoideum. Dev. Genet. 9, 561-568.

Sadeghi, H., Williams, K. e Klein, C. (1987) Characterization of antigen 117. J. Biol. Chem. 262, 16294-16299.

Saini, K. S., Summerhayes, I. C. e Thomas, P. (1990) Molecular events regulating messenger RNA stability in eukaryotes. Mol. Cell. Biochem. 96, 15-23.

Sambrook, J., Fritsch, E. F. e Maniatis, T. (1989) Molecular Cloning: a laboratory manual. Cold Spring Harbor Laboratory, Cold Spring Harbor, N.Y.

Saxe III, C. L., Johnson, R. L., Devreotes, P. N. e Kimmel, A. R. (1991) Expression of cAMP receptor gene of Dictyostelium and evidence for a multigene family. Genes Dev. $5,1-8$.

Shapiro, R. A., Herrick, D., Manrow, R. E., Blinder, D. e Jacobson, A. (1988) Determinants of mRNA stability in Dictyostelium discoideum amoebae: differences in poly(A)tail length, ribosome loading, and mRNA size cannot account for the heterogeneity of mRNA decay rates. Mol. Cell. Biol. 8, 1957-1969. 
Siegel, L. I. e Bresnick, E. (1986) Northern hybridization analysis of RNA using diethylpirocarbonate treated non-fat milk. Anal. Biochem. 159, 82-87.

Siu, C.-H., Cho, A. e Choi, A. H. C. (1987) The contact site A glycoprotein mediates cell-cell adhesion by homofilic binding in Dictyostelium discoideum. J. Cell Biol. 105, 2523-2533.

Siu, C.-H., Lam, T. Y. e Choi, A. H. C. (1985) Inhibition of cell-cell binding at the aggregation stage of Dictyostelium by monoclonal antibories directed against the contact site A glycoprotein. J. Biol. Chem. 260, 16030-16036.

Siu, C., Lam, T. Y. e Wong, L. M. (1988) Expression of the contact site A glycoprotein in Dictyostelium discoideum: quantitation and developmental regulation. Biochem. Biophys. Acta 968, 283-290.

Snaar-Jagalska, B. E., Kesbeke, F. e Van Haastert, P. J. M. (1988) G proteins in the signal transduction of Dictyostelium discoideum. Dev. Genet. 9, 215-226.

Soll, D. R. e Sussman, M. (1973) Transcription in isolated nuclei of the slime mold Dictyostelium discoideum. Biochim. Biophys. Acta 319, 312-322.

Southern, E. M. (1975) Detection of specific sequences among DNA fragments separated by gel electrophoresis. J. Mol. Biol. 98, 503-517.

Steinemann, C. e Parish, R. (1980) Evidence that a developmentally regulated glycoprotein is the target of Fab in reaggregation of Dictyostelium discoideum. Nature 286, 621-623.

Stadler, J., Keenan, T.W. Bauer, G. e Gerisch, G. (1989) The contact site A glycoprotein of Dictyostelium discoideum carries a phospholipid anchor of a novel type. EMBO J. 8,371-377.

Sussman, M. (1987) Cultivation and synchronous morphogenesis of Dictyostelium under controled experimental conditions. Methods in Cell Biol. 28,9-29. 
Sussman, M., Schindler, J. e Kim, H. (1977) Toward a biochemical definition of the morphogenetic fields in Dictyostelium in Development and differentiation in the cellular slime molds, pp. 31-50. Amsterdam, Elsevier.

Takahama, Y. e Singer, A. (1992) Post-transcriptional regulation of early $T$ cell development by $T$ cell receptor signals. Science $258,1456-1462$.

Tamaoki, T., Nomoto, H., Takahashi, I., Kato, Y., Morimoto, M. e Tomita, F. (1986) Staurosporin, a potent inhibitor of phospholipid/ $\mathrm{Ca}^{2+}$ dependent protein kinase. Biochem Biophys. Res. Comm. 135, 397-402.

Tao, Y. and Klein, C. (1990) Localization of functional domains of the CAMP chemotactic receptor of Dictyostelium discoideum. J. Biol. Chem. 265, 15584-15589.

Theibert, A. e Devreotes, P. N. (1986) Surface receptor-mediated activation of adenylate cyclase in Dictyostelium. J. Biol. Chem. 261, 15121-15125.

Van Haastert, P. J. M. (1984) Guanine nucleotides modulate cell surface cAMP-binding sites in membranes from Dictyostelium discoideum. Biochem. Biophys. Res. Comm. $124,597-604$.

Van Haastert, P. J. M. (1987) Down-regulation of cell surface cyclic AMP receptors and desensitization of cyclic AMP-stimulated adenylate ciclase by cyclic AMP in Dictyostelium discoideum. J. Biol. Chem. 262, 7700-7704.

Van Haastert, P. J. M. e De Wit, R. J. W. (1984) Demonstration of receptor heterogeneity and affinity modulation by nonequilibrium binding experiments. J. Biol. Chem. 259, 13321-13328.

Van Haastert, P. J. M., De Wit, R. J. W., Janssens, P. M. W., Kesbeke, F. e DeGoede, J. (1986) G-protein-mediated interconversions of cell-surface cAMP receptors and their involvement in excitation and desensitization of guanylate cyclase in Dictyostelium discoideum. J. Biol. Chem. 261, 6904-6911.

Van Haastert, P. J. M., De Wit, R. J. W. e Van Lookeren Campagne, M. M. (1985) $\mathrm{Ca}^{2+}$ - or phorbol ester-dependent effect of ATP on a subpopulation of cAMP cell- 
surface receptors in membranes of $D$. Discoideum. A role for protein kinase $\mathrm{C}$. Biochem. Biophys. Res. Comm. 128, 185-192.

Van Haastert, P. J. M., Janssens, P. M. W. e Erneux, C. (1991) Sensory transduction in Dictyostelium discoideum. Eur. J. Biochem. 195, 289-303.

Van Haastert, P. J. M. e Kien, E. (1983) Binding of cAMP derivatives to Dictyostelium discoideum cells. J. Biol. Chem. 258, 9636-9642.

Van Haastert, P. J. M., Wang, M., Borninaar, A. A., Devreotes, P. N. e Schaap, P. (1992) cAMP-induced desensitization of surface cAMP receptors in Dictyostelium: different second messengers mediate receptor phsphorylation, loss of ligand binding, degradation of receptor, and reduction of receptor mRNA levels. Mol. Biol. of the Cell 3, 603-612.

Van Lookeren Campagne, M. M., Emeux, C., Van Eijk, R. e Van Haastert, P. J. M. (1988) Two dephosphorylation pathways of inositol 1,4,5-trisphosphate in homogenates of the cellular slime mold Dictyostelium discoideum. Biochem. J. 254, 343-350.

Vaughan, R. A. e Devreotes, P. N. (1988) Ligand-induced phosphorylation of the cAMP receptor from Dictyostelium discoideum. J. Biol. Chem. 263, 14538-14543.

Wager, R. T. e Assoian, R. K. (1990) A phorbol ester-regulated ribonuclease system controlling transforming growth factor B1 gene expression in hematopoietic cells. Mol. Cell.Biol. 10, 5983-5990.

Wang, M. e Schaap, P. (1989) Ammonia depletion and DIF trigger stalk cell differentiation in intact Dictyostelium discoideum slugs. Development 105, 569-574.

Watts, D. J. e Ashworth, J. M. (1970) Growth of myxamoebae of the cellular slime mold Dictyostelium discoideum in axenic culture. Biochem. J. 119, 171-174.

Williams, J. G. (1991) Regulation of cellular differentiation during Dictyostelium morphogenesis. Current Opinion in Genetics and Development. 1, 358-362. 
Willians, J. G., Tsang, A. S. e Mahbubani, H. (1980) A change in the rate of transcription of a eukaryotic gene in response to cyclic AMP. Proc. Natl. Acad. Sci. USA. 77, 7171-7175.

Wong, L. M. e Siu, C. (1985) Cloning of cDNA for the contact site A glycoprotein of Dictyostelium discoideum. Prac. Natl. Acad. Sci. USA 83, 4248-4252.

Wurster, B., Nanjundiah, V. e Malchow, D. (1990) Calcium Oscillations in Dictyostelium discoideum, in Calcium as an intracellular messenger in eukaryotic microbes (O'Day, D. H., ed.) pp. 228-242. American Society for Microbiology, Washington, D.C.

Wick, U., Malchow, D. e Gerisch, G. (1978) Cyclic-AMP stimulated calcium influx into aggregating cells of Dictyostelium discoideum. Cell Biol. Int. Rep. 2, 71-79. 